MANOEL GALDINO DA SILVA JUNIOR

\title{
PROPOSTA DE METODOLOGIA PARA DIAGNÓSTICO TÉCNICO DA ILUMINAÇÃO PÚBLICA
}




\section{PROPOSTA DE METODOLOGIA PARA DIAGNÓSTICO TÉCNICO DA ILUMINAÇAO PÚBLICA}

Dissertação apresentada à Escola Politécnica da Universidade de São Paulo para obtenção do título de Mestre em Ciências

Área de Concentração: Engenharia Elétrica e Sistema de Potência

Orientador: Prof. Dr. Luiz Claudio Ribeiro Galvão 


\section{PROPOSTA DE METODOLOGIA PARA DIAGNÓSTICO TÉCNICO DA ILUMINAÇÃO PÚBLICA}

Dissertação apresentada à Escola Politécnica da Universidade de São Paulo para obtenção do título de Mestre em Ciências

Área de Concentração: Engenharia Elétrica e Sistema de Potência

Orientador: Prof. Dr. Luiz Claudio Ribeiro Galvão

Co-orientador: Prof. Dr. Marco Antonio Saidel 
Este exemplar foi revisado e corrigido em relação à versão original, sob responsabilidade única do autor e com a anuência de seu orientador.

São Paulo, de de

Assinatura do autor:

Assinatura do orientador:

\section{Catalogação-na-publicação}

Silva Junior, Manoel Galdino da

PROPOSTA DE METODOLOGIA PARA DIAGNÓSTICO TÉCNICO DA ILUMINAÇÃO PÚBLICA / M. G. Silva Junior -- versão corr. -- São Paulo, 2015. $105 \mathrm{p}$.

Dissertação (Mestrado) - Escola Politécnica da Universidade de São Paulo. Departamento de Engenharia de Energia e Automação Elétricas.

1. Iluminação Pública 2.lluminação Pública (Diagnóstico) 3.lluminação Pública (Sistemas) 4.lluminação Pública (Legislação) I.Universidade de São Paulo. Escola Politécnica. Departamento de Engenharia de Energia e Automação Elétricas II.t. 


\section{AGRADECIMENTOS}

Aos meus pais, in memorian, que sempre estiveram e sempre estarão presentes em todos os momentos da minha vida.

A minha esposa Odete Portela, que além de companheira de vida, foi crucial nas correções de textos.

Minha eterna gratidão ao meu amigo e companheiro, Professor Doutor Fernando Selles que me incentivou a voltar à academia num momento muito importante da minha vida.

Minha profunda gratidão pela sempre segura orientação do Professor Doutor Marco Antonio Saidel.

Agradecimento especial ao meu orientador, Professor Doutor Luiz Claudio Ribeiro Galvão, pela oportunidade de realizar meu sonho.

A Diretoria da LBR Engenharia \& Consultoria, nas pessoas dos engenheiros Orlando, La Bella. José Fernando e William, com quem tive a grata satisfação de trabalhar no período em que desenvolvi esse estudo.

A equipe da Medral Geo-tecnologia, em especial ao engenheiro José Roberto Del Bianco, que participou efetivamente para a conclusão desse estudo. 
"Assumir nossos erros exige muita coragem em um mundo que parece feito de pessoas que sempre ganham todas...

Assumir nossa ignorância exige muita humildade nesse mundo de quem sabe tudo". 


\section{RESUMO}

A Iluminação Pública (IP) está num momento de profundas mudanças, principalmente com a popularização da tecnologia LED e dos sistemas de controle a distância. O gestor de serviços públicos precisa conhecer a complexidade do uso final da IP para que possa gerir esse ativo direcionado às necessidades dos usuários, tendo em vista o dinamismo de evolução diária dos centros urbanos. Este estudo tem por objetivo desenvolver uma metodologia que permite levantar, cadastrar, diagnosticar e avaliar, o parque de IP existente em ambientes urbanos. Tem como questão de pesquisa: Como prover os gestores de serviços públicos de conhecimento da situação dos ativos de IP? Trata-se de uma pesquisa observacional e descritiva, desenvolvida em uma região que compreende uma área de $26,5 \mathrm{~km}^{2}$, com uma população de 344.632 habitantes, localizada em uma região metropolitana brasileira. A metodologia aplicada divide-se em dois momentos: pesquisa documental e de campo. Inicia-se com um levantamento de documentações a respeito da vida pregressa do acervo, disponíveis nos escritórios da Concessionária de Energia local e da Prefeitura Municipal. Posteriormente procede-se uma identificação do perfil da cidade, onde o sistema de iluminação está inserido, buscando compreender como o sistema de IP instalado está integrado às necessidades da população. Essas primeiras ações visam recolher subsídios para a etapa seguinte, de levantamento técnico em campo, que buscou identificar não só os atributos de IP existentes para atualização cadastral, como também identificou anomalias que estavam atrapalhando o desempenho do sistema e a influência provocada pelo meio onde está inserido. A metodologia pode ser uma ferramenta que contribui para a gestão do serviço de IP inserida dentro dos centros urbanos, possibilitando a adoção de medidas de ajustes que visem dotar o acervo de IP de uma estrutura de manutenção direcionada para cada região da cidade, considerando sua especificidade e perfil dos usuários. Antes de qualquer adoção de novas tecnologias, como por exemplo lâmpadas LED, telecomando, etc., é imprescindível que se tenha um diagnóstico do acervo existente e a identificação do uso final da IP no meio em que se encontra.

Palavras chaves: Iluminação Pública. Diagnóstico. Serviços Públicos. 


\begin{abstract}
Public lighting is in a moment of deep changes, especially with the popularization of LED technology and distance control systems. The public manager must know the complexity of the final use of public lighting that can then manage those assets directed to the needs of users, given the dynamism of daily evolution of urban centers. This study aims to develop a methodology that allowed: to collect data, to register, to diagnose and evaluate the existing street lighting park in urban environments. It had as research issue: How to provide public service managers knowledge concerning to public lighting of the current situation? This is an observational and descriptive research, developed in a region that covers an area of $26.5 \mathrm{~km}^{2}$, with a population of 344,632 inhabitants located at a Brazilian region metropolitan. The method used is divided into two stages: the documentary and field research. It begins with a survey of documentation regarding the early life of the acquis in order, available at the offices of the local Power Concessionaire and Municipal Government. Later there shall be an identification of the city profile, where the lighting system is inserted, seeking to understand how is the installed street lighting system integrated into the population's needs. These first actions aimed at garnering information for the next stage, technical field survey, which sought to identify not only the existing street lighting attributes for the database update, as well as to identify anomalies that were hindering the system performance and the influence caused by the means in which it operates. The questionnaire presented in this study, can be a tool that contributes to the management of public lighting inserted in urban centers, allowing the adoption of adjustment measures to provide the public lighting acquis of a maintenance structure directed to each region of the city, considering its specificity and user profiles. Before any adoption of new technologies, such as LED lamps, remote control, etc., it is essential to have a diagnosis of the existing acquis and the identification of the end-use of public lighting in the environment in which it is located.
\end{abstract}

Keywords: Public Lighting. Diagnostic. Public Managers. 


\section{LISTA DE FIGURAS}

Figura 1: Primeiro poste elétrico da cidade de Campos dos Goitacazes, RJ ...........................25

Figura 2: Poste com luminárias elétricas na Av. Rio Branco (RJ), 1921 ................................27

Figura 3: Iluminação com lâmpadas de vapor metálico na Av. Paulista, SP ...........................27

Figura 4: Foto da Estação Espacial, visão noturna da região da Itália .....................................28

Figura 5: Esquema de ligação elétrica do sistema de IP ........................................................39

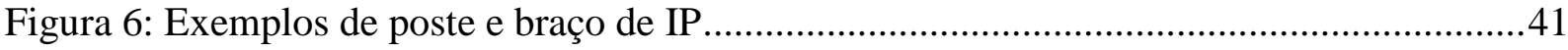

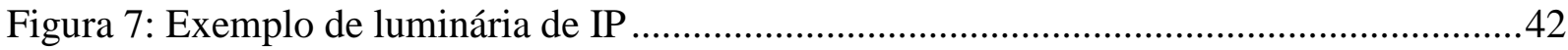

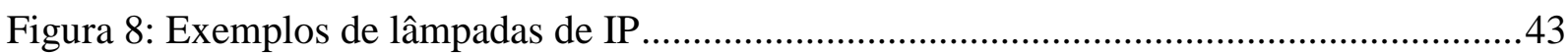

Figura 9: Exemplo de chave magnética, caixa de proteção e relé fotoelétrico..........................43

Figura 10: Exemplo de iluminação especial. Monumento às Bandeiras (SP) ...........................44

Figura 11: Distribuição de intensidade luminosa - Identificação do ponto escuro.....................55

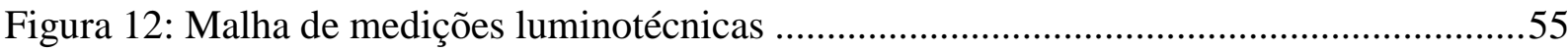

Figura 13: Metodologia de medição pela NBR 5101/2012 para uma faixa de rolamento. .......56

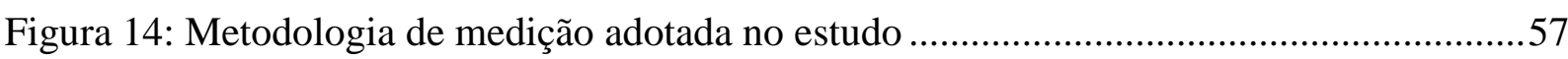

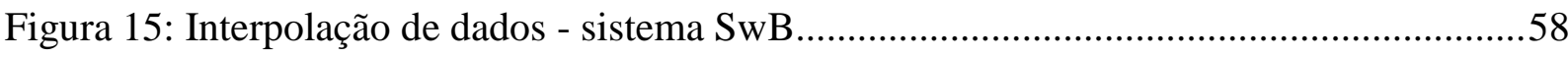

Figura 16: Levantamento fotométrico com veículo................................................................59

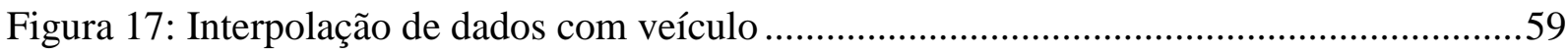

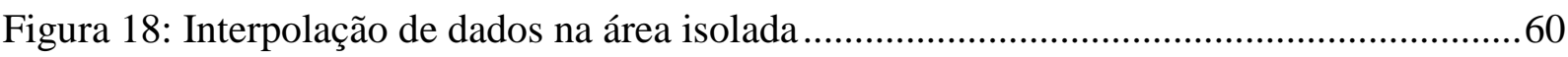

Figura 19: Comparação entre os procedimentos de medição ....................................................60

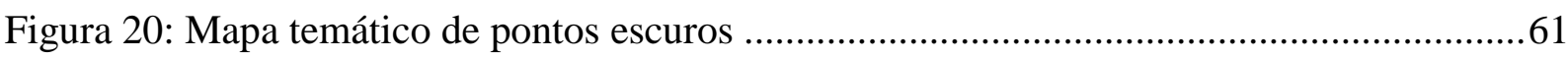

Figura 21: Luxímetro utilizado nas medições fotométricas ...................................................62

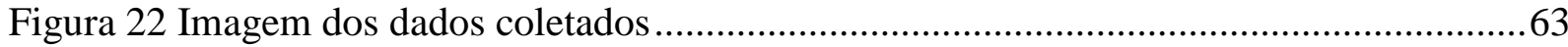

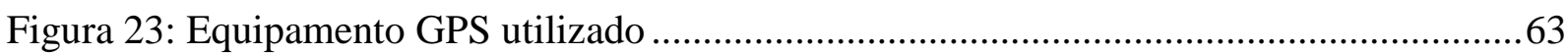

Figura 24: Diagrama esquemático do levantamento de dados ...............................................66 


\section{LISTA DE TABELAS}

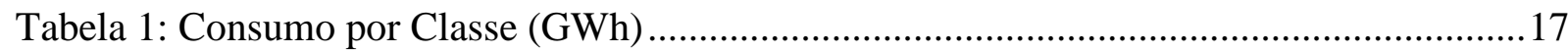

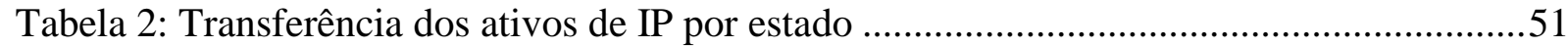

Tabela 3: Medições fotométricas em diferentes alturas .........................................................61

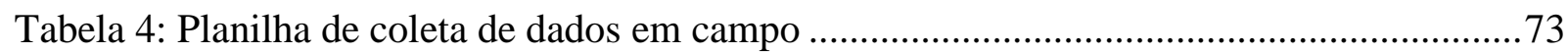

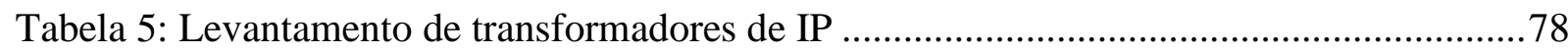

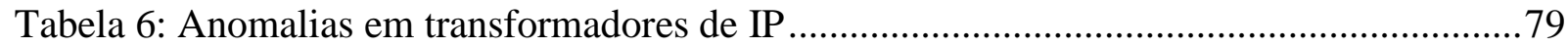

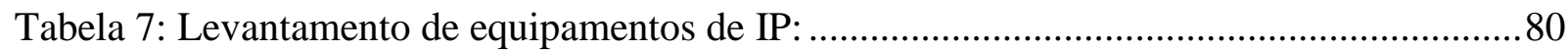

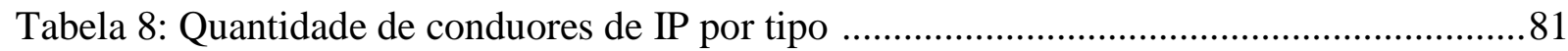

Tabela 9: Quantidade de anomalias em condutores por tipo ..................................................82

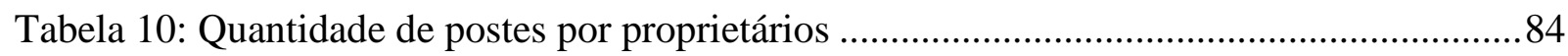

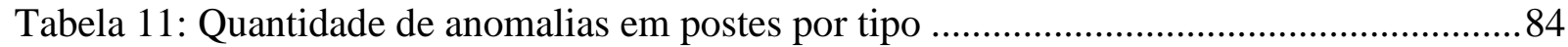

Tabela 12: Quantidade de anomalias em braços de IP ............................................................ 86

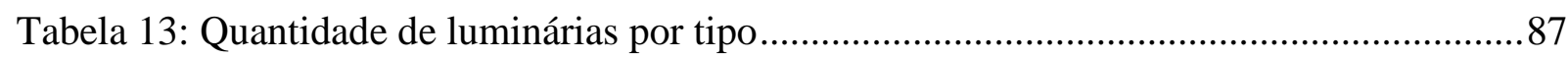

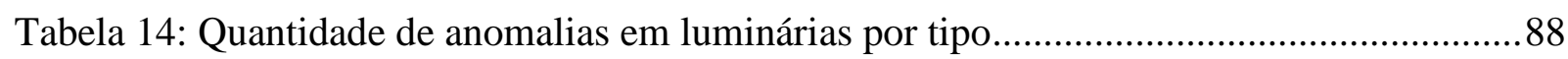

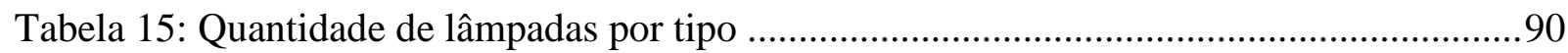

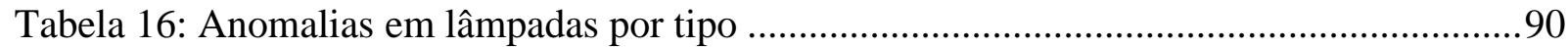

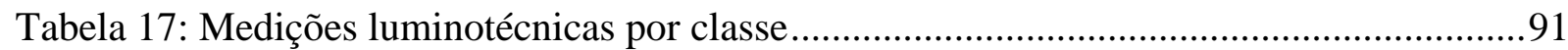

Tabela 18: Percentual de medições luminotécnicas por classe ...............................................92

Tabela 19: Cruzamento de dados IBGE e dados coletados ......................................................94

Tabela 20: Análise estatística dos dados ...............................................................................95

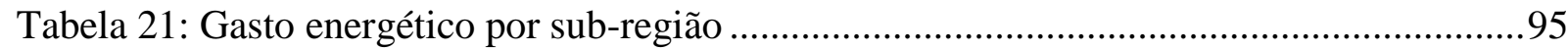

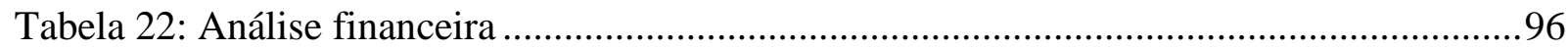




\section{LISTA DE GRÁFICOS}

Gráfico 1: Distribuição geográfica dos pontos de IP no Brasil ...............................................16

Gráfico 2: Representação do fator de manutenção - FM ............................................................48

Gráfico 3: Benefício marginal e custo de qualidade .................................................................50

Gráfico 4: Percentual de anomalias em transformadores ..................................................... 79

Gráfico 5: Percentual quantitativo de equipamentos de IP .................................................. 80

Gráfico 6: Percentual de quantidade de condutores de IP por tipo.......................................... 82

Gráfico 7: Percentual de anomalias em condutores de IP por tipo ............................................83

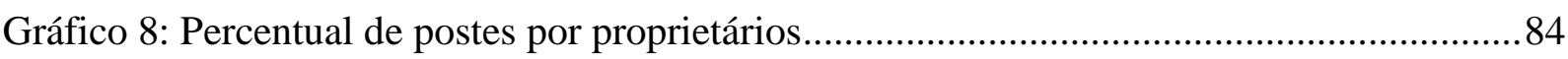

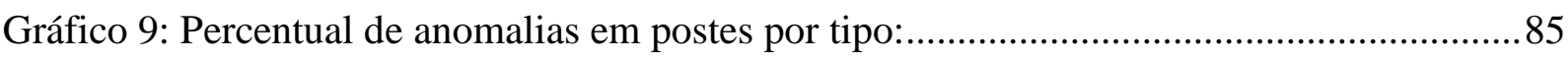

Gráfico 10: Percentual de anomalias em braços de IP ........................................................ 86

Gráfico 11: Percentual de anomalias em luminárias por tipo................................................8

Gráfico 12: Percentual de anomalias em lâmpadas por tipo......................................................90

Gráfico 13: Percentual de medições luminotécnicas por classe .............................................92

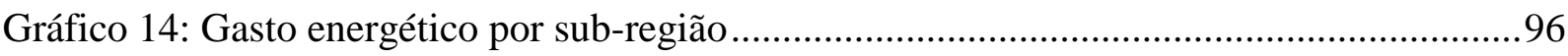




\section{LISTA DE ABREVIATURAS}

AIS

ANEEL

CNM

CIP

COSIP

DINAEE

ELETROBRÁS

EPE

FMIP

FM

FSL

FMLL

GIS

GPS

IASC

IBGE

ILUME

INMETRO

IPTU

IP

LC

LED

NBR

Procel

WWW
Ativo Imobilizado em Serviço

Agência Nacional de Energia Elétrica

Confederação Nacional dos Municípios

Contribuição de Iluminação Pública

Contribuição para Custeio da Iluminação Pública

Departamento Nacional de Águas e Energia Elétrica

Centrais Elétricas Brasileiras

Empresa de Pesquisa Energética

Fundo Municipal de Iluminação Pública

Fator de Manutenção

Fator de Sobrevivência

Fator de Manutenção da Luminosidade da Lâmpada

Geographic Information System

Global Positioning System

Índice ANEEL de satisfação do consumidor

Instituto Brasileiro de Geografia e Estatística

Departamento de Iluminação Pública da Cidade de SP

Instituto Nacional de Metrologia, Qualidade e Tecnologia

Imposto Predial Territorial Urbano

Iluminação Pública

Lei Complementar

Light Emitting Diode

Norma Brasileira Regulamentadora

Programa de conservação de energia elétrica

World Wide Web 


\section{SUMÁRIO}

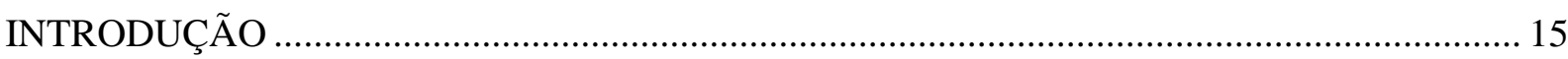

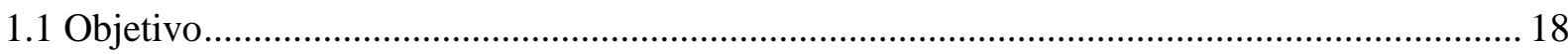

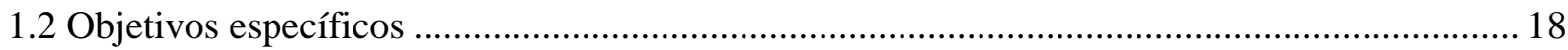

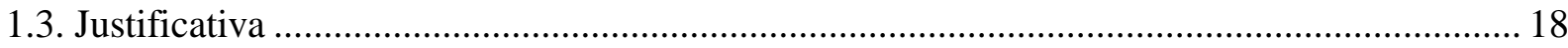

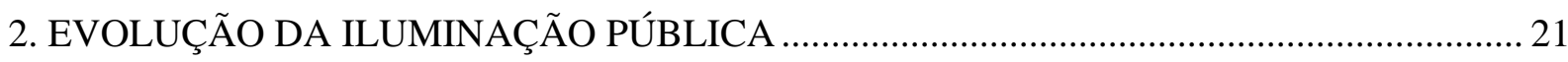

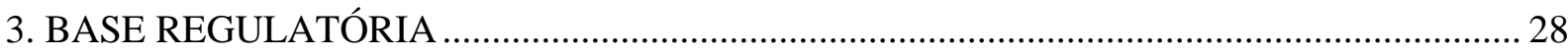

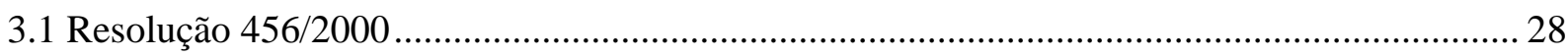

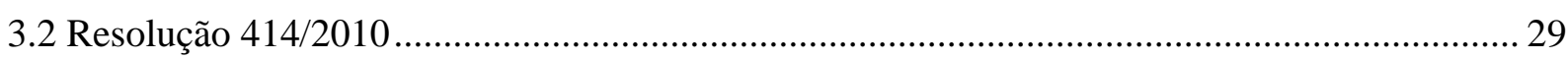

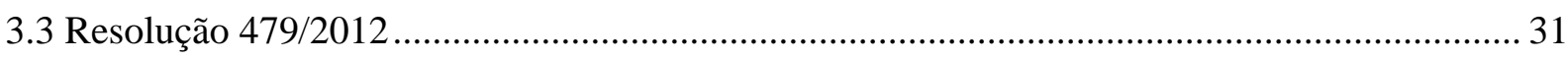

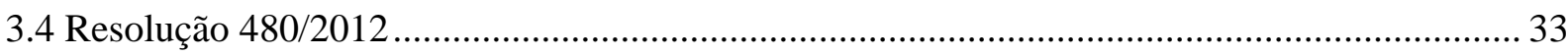

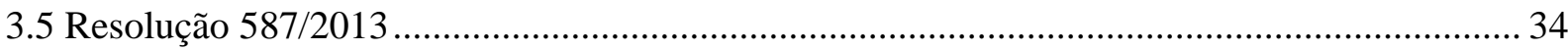

3.6 COSIP - Contribuição para o custeio do serviço de IP ........................................................... 35

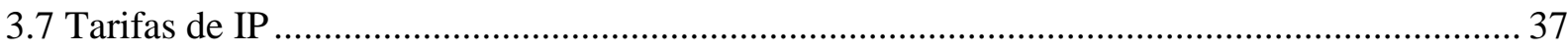

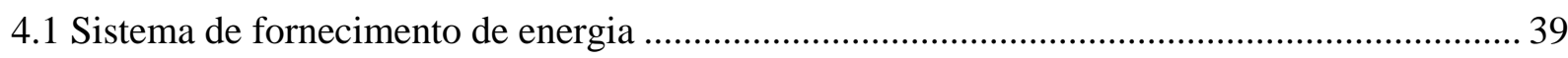

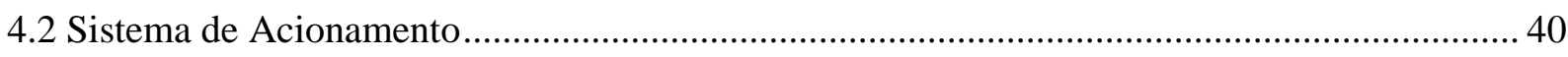

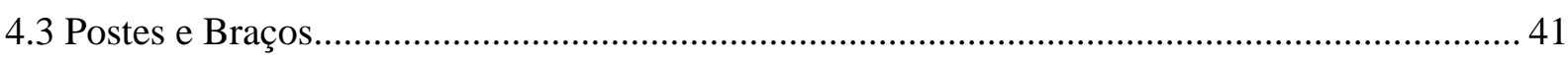

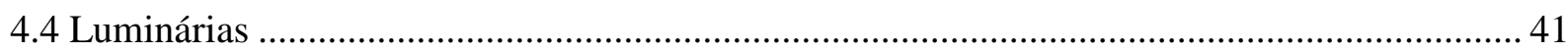

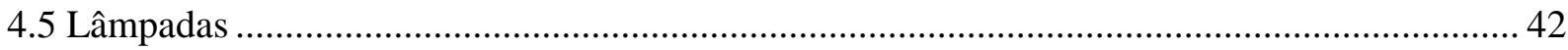

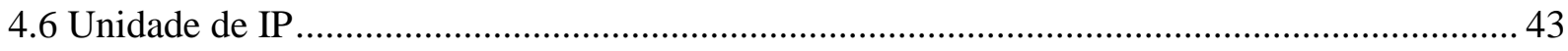

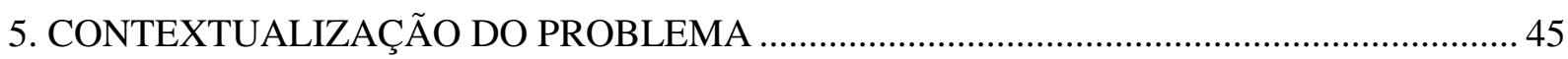

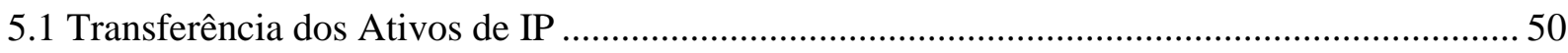

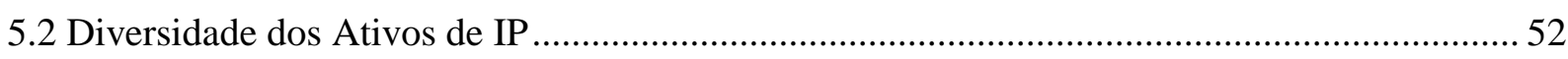

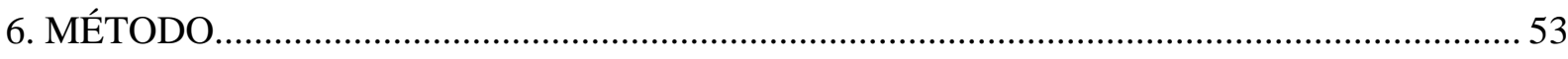

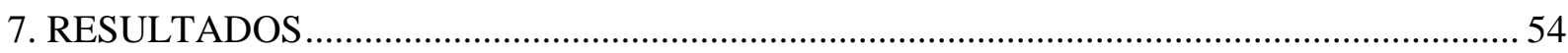

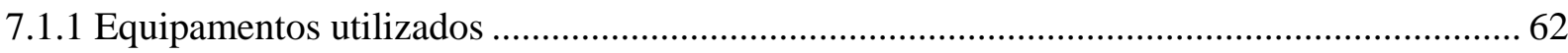




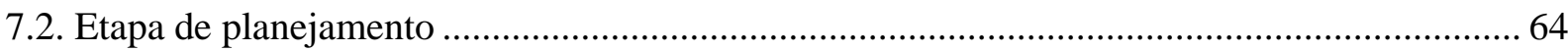

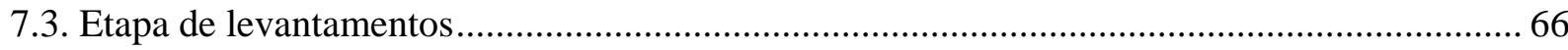

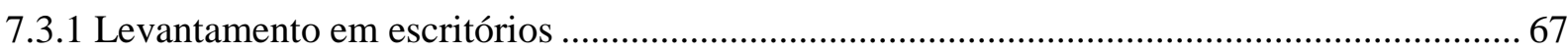

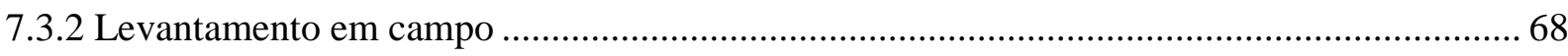

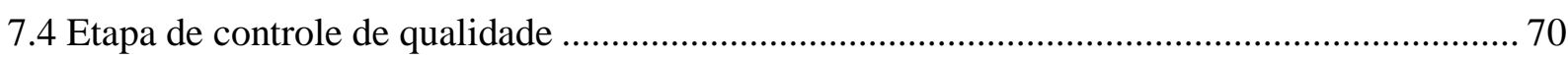

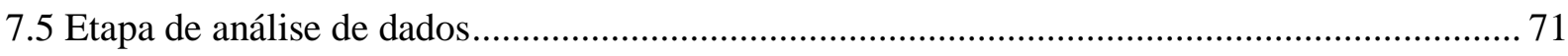

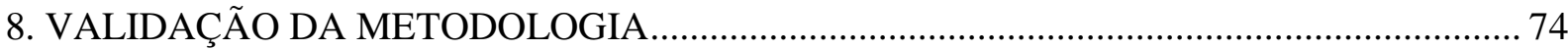

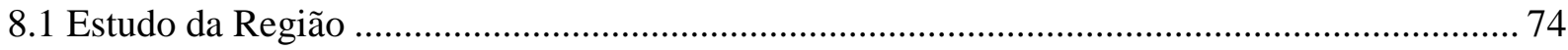

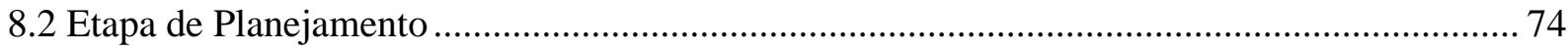

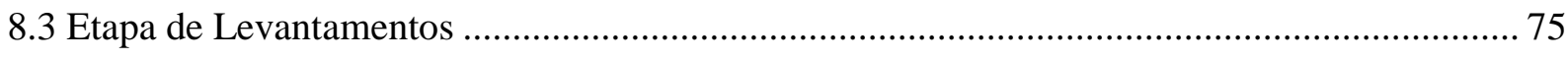

8.3.1 Levantamento de documentações ............................................................................ 75

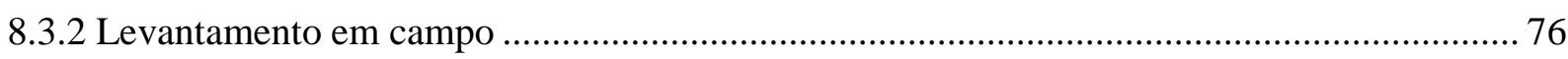

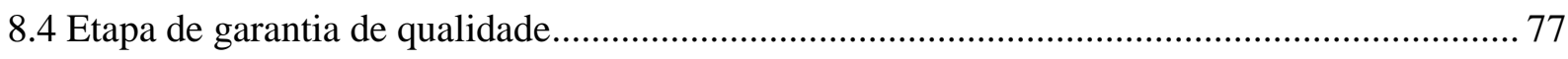

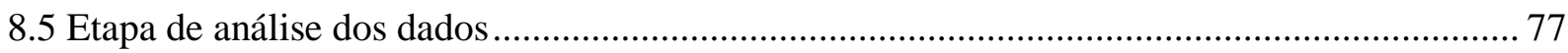

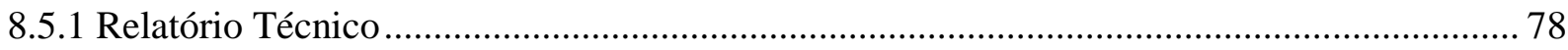

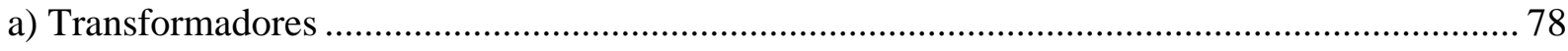

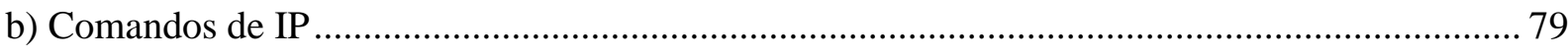

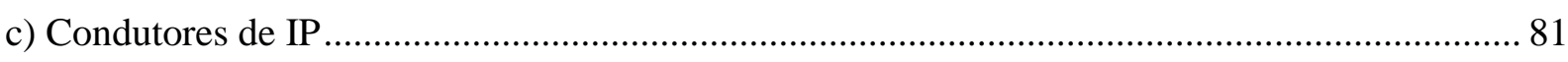

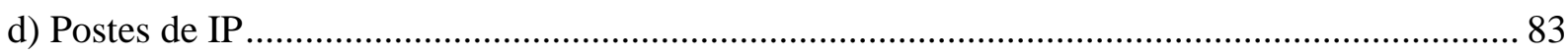

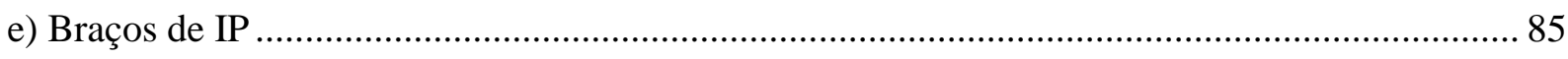

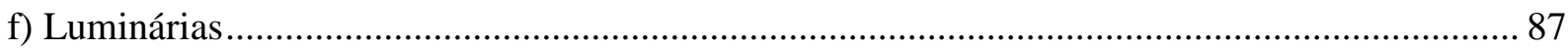

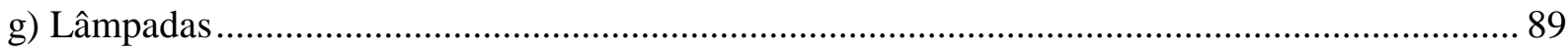

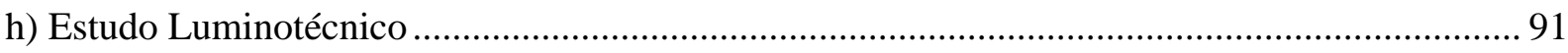

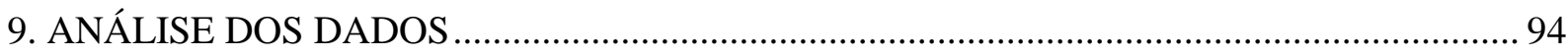

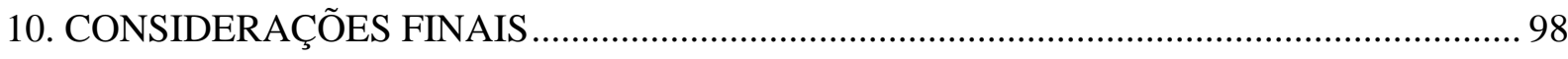

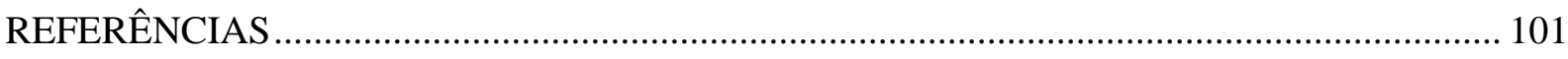




\section{INTRODUÇÃO}

A iluminação pública (IP) está inserida no cotidiano das cidades, como um ativo municipal que presta grande serviço à população, pois além de propiciar claridade às vias públicas, também dá suporte a diversas outras funções sociais, como segurança, lazer, conforto, etc. Permite as pessoas utilizarem os espaços públicos de forma mais segura e viável, já que dá condições para que enxerguem o que está acontecendo ao seu redor. Hoje, a sensação de qualidade de vida da população, principalmente em grandes centros urbanos, está ligada à possibilidade de aproveitamento dos espaços públicos em períodos noturnos, razão pela qual a IP é tão importante.

Porém, a gestão da IP não é uma tarefa fácil, tendo em vista que seus equipamentos estão dispersos por toda a cidade, dificultando sua manutenção, controle técnico e orçamentário. A fim de manter a continuidade dos serviços, é necessária uma adequada rotina de manutenção preventiva, cujo principal objetivo é evitar as ocorrências corretivas ou de emergência. Entretanto, são justamente as ocorrências corretivas que geralmente acontecem em maior escala, tendo em vista a falta de mecanismos de monitoramento que propiciem antecipar ações preventivas de manutenção. Em grandes centros urbanos, onde as dificuldades de locomoção são maiores devido ao trânsito de veículos e o grande fluxo de pessoas, esse problema se agrava amentando a sensação de insegurança causada pela precariedade dos sistemas de IP, causando uma insatisfação da população quanto à qualidade do serviço prestado. Nesse sentido, questionase: Quem é o responsável pela gestão do sistema de IP?

A Constituição Federal de 1988, em seu artigo 30, item V, define que "Compete aos Municípios, organizar e prestar, diretamente ou sob regime de concessão ou permissão, os serviços públicos de interesse local, incluindo o transporte coletivo, que tem caráter essencial" (CONSTITUIÇÃO FEDERAL DO BRASIL, 1988). Com base nisso o Governo Federal resolve, através da Resolução 414 (2010), transferir para as prefeituras o acervo de IP existentes no território nacional, onde em seu artigo n 218 determina que "a distribuidora deve transferir o sistema de IP registrado como Ativo Imobilizado em Serviço - AIS à pessoa jurídica de direito público competente".

Conforme levantamento feito pela Agência Nacional de Energia Elétrica - ANEEL, 32,51\% dos ativos de IP existentes no Brasil estão em poder das Distribuidoras de Energia Elétrica, sendo que 67,49\% já estão em poder das Prefeituras (ANEEL, 2014). 
A atividade de IP, apesar da sua origem vinculada à gestão municipal, em muitas cidades ficou delegada à gestão da concessionária de energia elétrica local, devido principalmente à sua estrutura técnica para atendimento às redes de distribuição de energia. Como, na maioria das vezes, o ente municipal não tem uma estrutura técnica de projetos e manutenção que permita atender todo o parque de IP da cidade, se vê obrigado a contratar a própria concessionária local ou empresas especializadas para essas atividades. A falta de instrumentos de fiscalização eficientes deixa as prefeituras reféns de contratos que nem sempre atendem aos interesses da população.

A distribuição geográfica dos pontos de IP no Brasil, demonstrado na figura 1, indica que a maior parte do ativo se encontra na região sudeste, sendo a cidade de São Paulo a detentora de um dos maiores acervos de IP do mundo, com mais de 560.000 pontos.

\section{Gráfico 1: Distribuição geográfica dos pontos de IP no Brasil}

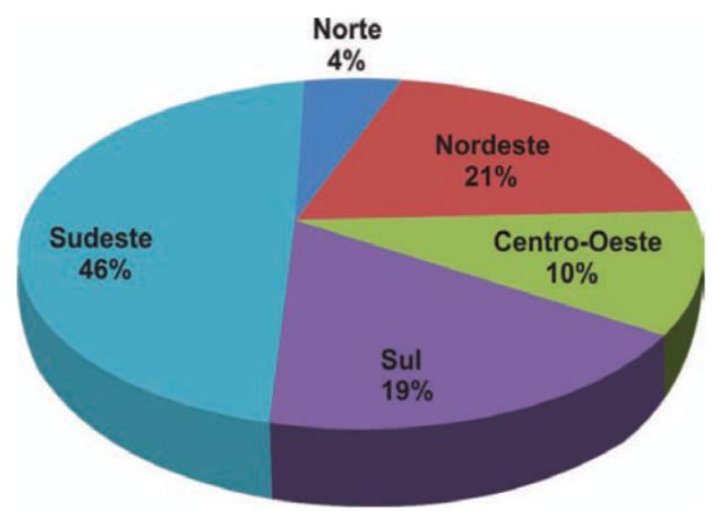

Fonte: Resultados Procel (2014)

A IP no Brasil corresponde a aproximadamente 4,5\% da demanda nacional de energia elétrica e a 3\% do consumo total de energia elétrica (GWh) no País (Tabelas 1 - EPE, 2014), com seu pico de consumo ocorrendo nos horários de ponta do sistema, estando intimamente ligada ao setor de segurança pública e transporte de pedestres. 
Tabela 1: Consumo por Classe (GWh)

\begin{tabular}{lrrrrrrrr} 
& 2009 & 2010 & 2011 & 2012 & 2013 & $\begin{array}{c}\Delta \% \\
(2013 / 2012)\end{array}$ & $\begin{array}{c}\text { Part. \% } \\
(2013)\end{array}$ \\
Brasil & 384.306 & 415.683 & 433.034 & 448.171 & 463.335 & 3,4 & 100,0 \\
\hline Residencial & 100.776 & 107.215 & 111.971 & 117.646 & 124.896 & 6,2 & 27,0 \\
Industrial & 161.799 & 179.478 & 183.576 & 183.475 & 184.609 & 0,6 & 39,8 \\
Comercial & 65.255 & 69.170 & 73.482 & 79.226 & 83.695 & 5,6 & 18,1 \\
Rural & 17.304 & 18.906 & 21.027 & 22.952 & 23.797 & 3,7 & 5,1 \\
Poder público & 12.176 & 12.817 & 13.222 & 14.077 & 14.608 & 3,8 & 3,2 \\
\hline Iluminação pública & 11.782 & 12.051 & 12.478 & 12.916 & 13.512 & 4,6 & 2,9 \\
Serviço público & 12.898 & 13.589 & 13.983 & 14.525 & 14.847 & 2,2 & 3,2 \\
Próprio & 2.319 & 2.456 & 3.295 & 3.354 & 3.372 & 0,5 & 0,7 \\
\hline
\end{tabular}

Fonte: Anuário Estatístico EPE, 2014

Considerando que a maior parte do parque de IP instalados no Brasil ainda carece de ações de eficiência energética, visando buscar o melhor custo/benefício para a população, a Eletrobrás, através do Procel Reluz, programa que visa promover o desenvolvimento de sistemas eficientes de IP e sinalização semafórica, vem desde 1994, tentando modernizar o parque de IP no Brasil. Dos cerca de 16 milhões de pontos de IP existentes no país, já houve mais de dois milhões de pontos eficientizados em mais de 1.300 municípios brasileiros, somando mais de $\mathrm{R} \$ 500$ milhões em investimentos. No ano de 2013 o consumo de energia elétrica no Brasil foi de 463.335 GWh (EPE, 2014), o Procel Reluz contribuiu para uma economia de 9.730 GWh, equivalente a $2,1 \%$ de todo o consumo nacional de energia elétrica naquele ano, e uma redução de demanda na ponta de $3.769 \mathrm{MW}$, a partir de financiamento, no valor total de $\mathrm{R} \$ 34.400 .000$, para a substituição de 62 mil pontos de IP (PROCEL, 2014). Um esforço muito válido no aspecto "resultado de eficiência energética", porém ainda insuficiente quanto às necessidades e expectativas dos clientes finais, que almejam um parque de IP mais eficiente, com resultados finais que expressem uma maior sensação de segurança e possiblidade de lazer noturno e acima de tudo com baixos custos aos cofres públicos.

Visando contribuir para a evolução da qualidade do serviço de IP, este estudo tem por objetivo o desenvolvimento de uma metodologia que permite levantar, cadastrar, diagnosticar e avaliar, por meio de método de pesquisa descritiva e explicativa, o parque de IP existentes em ambientes urbanos, que subsidie o gestor, seja ele municipal ou privado, nas tomadas de decisões, considerando o perfil da cidade e de seus cidadãos. 


\subsection{Objetivo}

A presente dissertação tem como objetivo propor uma metodologia para diagnóstico do sistema de distribuição de iluminação pública existentes nas cidades, que possa dar suporte a gestores de serviços públicos nas tomadas de decisões.

\subsection{Objetivos específicos}

Levantamento Patrimonial: descrever a metodologia utilizada para o levantamento do acervo de IP;

Levantamento Técnico/Operativo: descrever a metodologia utilizada para identificar anomalias e insuficiência de fluxo luminoso (pontos escuros).

\subsection{Justificativa}

A palavra "diagnóstico" é definida como um processo analítico de que se vale o especialista ao exame de uma doença ou de um quadro clínico, para chegar a uma conclusão. Relativo à diagnose. Qualificação dada por um médico a uma enfermidade ou estado fisiológico, com base nos sinais que observa (MICHAELIS, 2014). Esse conceito, usado na medicina, de se estabelecer um conjunto de dados formado a partir de sinais e sintomas para identificar doenças, também pode ser utilizado para definir a situação em que se encontra uma máquina ou um equipamento.

Da mesma forma como não é recomendado a um médico prescrever um medicamento antes de examinar seu paciente, solicitar exames clínicos, analisar o caso e definir um diagnóstico, também não é recomendado a um gestor definir como será conduzido ou operado um sistema técnico, como por exemplo, o sistema de IP, sem antes obter um diagnóstico da situação dos ativos que compõem esse sistema, sendo condição "sine qua non" para qualquer estudo luminotécnico. Portanto, antes de se preocupar com a IP propriamente dita, é necessário avaliar como os materiais e equipamentos estão se comportando no seu regime de funcionamento diário, assim como fazer um estudo da cidade onde o sistema de IP está inserido, a fim de perceber quais as características físicas, arquitetônicas e de uso final das ruas, avenidas, praças, etc., para saber como a população se utiliza e convive diariamente com esse bem público no período 
noturno. Assim, será possível notar a real necessidade dos usuários, seus costumes, valores, carências, etc., e assim, prever um projeto aderente a quem efetivamente usa a IP.

Conforme Basso (2008), a impressão da cidade durante o dia pode sofrer grande alteração quando visualizada durante a noite. É importante que o projeto de iluminação tenha uma preocupação com o ambiente onde está inserido e com o uso final do produto pelos usuários e não apenas sua característica técnica relacionada ao desempenho, como por exemplo, a quantidade de luz que chega até o solo ou ao objeto a ser iluminado. É evidente que existem diferenças inevitáveis entre o uso do espaço urbano durante o dia e sua utilização durante a noite. Um dos atributos responsáveis pela modificação da ambiência ${ }^{1}$ do local é a IP, portanto, a intensidade dessas diferenças é definida de acordo com o projeto luminotécnico (ou a falta de um) que atende cada local, que podem promover e intensificar a utilização do espaço ou afastar os usuários que necessitam de luz adequada para suas atividades noturnas. Portanto, um projeto de IP precisa não apenas prover de luz um ambiente escuro, que, apesar de estar orientado por norma técnica, precisa também atender a alguns requisitos importantes, como: segurança, arquitetura urbana e circulação de pessoas e veículos.

Como a IP está num momento de profundas mudanças, principalmente com a popularização da tecnologia LED, dos sistemas de controle a distância e, sobretudo, da questão da transferência dos ativos de IP para as Prefeituras, o gestor público do sistema de IP, seja ele pertencente a uma prefeitura ou a uma concessionária de distribuição de energia elétrica, precisa estar atualizado com as diversas tecnologias disponíveis, sobretudo, conhecer profundamente o que tem nas mãos, para que possa optar pelo que mais se adeque a sua realidade, a fim de promover a evolução sustentável da infraestrutura e do serviço de IP. Evidentemente que a transferência de responsabilidade da gestão do sistema de IP para o ente municipal precisa ser conduzida com o devido cuidado, considerando que o gestor público muitas vezes não tem a adequada expertise sobre o assunto. É preciso buscar uma adequada assessoria técnica, seja com o suporte de profissionais conhecedores do negócio ou com a contratação de empresas que desempenhem essa função respeitando os gastos públicos.

Para um melhor entendimento, é preciso se fazer uma distinção entre a infraestrutura de IP e do serviço de IP. A infraestrutura de IP compreende a rede física propriamente dita de

\footnotetext{
${ }^{1}$ Ambiência: é o espaço organizado e animado que constitui um meio físico e, ao mesmo tempo, meio estético ou psicológico, especialmente preparado para o exercício de atividades humanas. Para além da distribuição espacial material, a ambiência denota um estilo de vida e se liga à apropriação, ao arranjo, ao embelezamento do espaço. Uma boa ambiência torna um espaço mais receptivo e propício ao convívio. A ambiência se apoia tanto em aspectos subjetivos, como o bom gosto, variável entre as distintas culturas, quanto a aspectos objetivos, como a luminosidade, a amplitude ou o clima do ambiente.
} 
lâmpadas, luminárias, braços, etc.; da mesma forma que a infraestrutura de abastecimento de água, com suas tubulações, registros, válvulas, etc. Já o serviço de gestão de IP ou do abastecimento de água, corresponde à operação, a tarifação e a manutenção da infraestrutura instalada.

As questões urbanas estão presentes nos diversos níveis de governo, seja federal, estadual ou municipal, porém observa-se que estão muito mais presentes ao nível dos Municípios, que segundo a Constituição Federal (1988), tem competência para legislar sobre assuntos de interesse local, reforçado no artigo 182, onde o poder público municipal deve executar a política de desenvolvimento urbano, ordenando o pleno desenvolvimento das funções sociais da cidade e garantindo o bem-estar de seus habitantes (CONSTITUIÇÃO FEDERAL DO BRASIL, 1988).

Como observa Kurahassi (2006) "ao longo dos anos está havendo uma transferência de responsabilidade dos Governos Federal e Estaduais, para a iniciativa privada e para os entes municipais, que a priori, estão mais próximos da população".

Seguindo essa linha de pensamento temos:

A descentralização política ocorrida após a constituição de 1988 trouxe aos municípios atribuições que até então eram de competência exclusiva do poder federal. A necessidade de um aumento na oferta de serviços públicos de interesse local agravou as dificuldades financeiras de muitos municípios, criando um contexto onde a boa gestão dos recursos é condição essencial para que as administrações municipais possam melhorar a qualidade dos serviços ofertados para a população. (KURAHASSI, 2006)

Hoje, passados 26 anos da promulgação da Constituição vigente, temos visto que essa tendência de transferência de responsabilidades aos municípios é uma constante, sem, no entanto, transferir na mesma proporção, condições adequadas para que os mesmos possam dar continuidade ou até melhorar os serviços que os cidadãos têm direito.

Como adianta Aureliano (1996) "para ser eficiente na sua implementação, a descentralização exige o desenvolvimento de uma capacidade gerencial, o que não ocorre de um dia para o outro". Seguindo esta linha de pensamento, questiona-se: as prefeituras estão preparadas para esse novo paradigma? 
Para Pfeiffer (2000), a transferência de responsabilidades feitas pelo governo central para os municípios não costuma ser precedida de uma preparação e fortalecimento, para que estes tenham condições reais de assumir os seus novos compromissos, portanto cabe aqui outro questionamento: Como prover os gestores de serviços públicos de conhecimento da situação dos ativos de IP?

É justamente para responder a essa pergunta que se centraliza a proposta desse estudo, ou seja, prover aos gestores uma metodologia que os ajude na gestão do acervo de IP, identificando as deficiências existentes no sistema, como por exemplo, possíveis desconformidades com as características da via pública, pontos com deficiência de luminosidade que causam espaços escuros entre os pontos de luz (pontos escuros), anomalias que podem estar prejudicando o funcionamento do sistema e, acima de tudo, se o nível mínimo de fluxo luminoso definidos pela norma NBR 5101, estão sendo respeitados.

Na pesquisa bibliográfica efetuada não foram identificadas metodologias de diagnóstico de IP similares à que está sendo proposta. As metodologias existentes são destinadas ao diagnóstico de materiais e equipamentos novos de IP, onde comumente os fornecedores submetem seus produtos para testes em busca de certificações que possibilitem serem aceitos pelo mercado, ou o próprio cliente que solicita um laudo para autenticar as informações fornecidas pelos fornecedores. Podemos citar como exemplo, o Programa de IP do Instituto Nacional de Metrologia, Qualidade e Tecnologia - INMETRO, autarquia federal, vinculada ao Ministério do Desenvolvimento, Indústria e Comércio Exterior, que oferece aferição de eficiência energética em lâmpadas e luminárias destinadas a IP, emitindo um relatório de ensaio atestando a capacidade e a eficiência dos produtos, que dá suporte ao processo de compra de fornecedores, prefeituras e concessionárias.

A relevância deste estudo está no fato de que a metodologia para diagnóstico da IP poderá ser utilizada por diversos profissionais, principalmente aqueles que trabalham diretamente para prefeituras municipais, consistindo assim de uma ferramenta de gestão que contribuirá no controle e planejamento de iluminação municipal, como define a Resolução ANEEL 414/2010.

\section{EVOLUÇÃO DA ILUMINAÇÃO PÚBLICA}

Conforme Rosito (2009), desde a pré-história, o ser humano tenta vencer a escuridão, buscando a utilização da iluminação natural e artificial. Há indícios arqueológicos que nos 
povos antigos, faziam uso da iluminação artificial por meio da utilização de óleos. Contudo, foi a partir da Idade Média, com a evolução do comércio, que aumentou a necessidade de se utilizar o período noturno para o trânsito de mercadorias. Vencer a escuridão tornou-se um desafio.

Iwashita (2011) comenta que, desde a Idade Média os seres humanos vinham tentando resolver o problema da escuridão com velas e outros artefatos. Neste período, eram usadas tochas com fibras torcidas e impregnadas com material inflamável. Foi, sobretudo, no século XV que a iluminação pública se tornou uma preocupação nas cidades. Isso porque a história aponta o ano de 1415, na Inglaterra, como a data do embrião da iluminação urbana, que nasceu como uma solução para amenizar a violência e, principalmente, os roubos a comerciantes, que aconteciam com frequência na região.

Em 1802, William Murdock, engenheiro e inventor escocês, aperfeiçoou uma tecnologia criada pelos ingleses, durante a revolução industrial, quando buscaram soluções mais eficientes para seus processos produtivos, através da destilação do carvão de pedra que gerava uma série de compostos de carbono, de alto poder calorífico e característica iluminantes. Com a ajuda de Matthew Boulton, engenheiro e industrial inglês, instalou dois abajures a gás em ambiente externo. Naquele momento a tecnologia de iluminação a gás iniciava sua escalada pelo mundo. Em 1812, foi fundada a National Light and Heat Company, quando, em 1814, surgiram as primeiras ruas iluminadas a gás encanado (ENCYCLOPÆDIA BRITANNICA, 2014)

Apesar de Thomas Edison ser reconhecido como o inventor da lâmpada, consta que ele aperfeiçoou e tornou comerciável um produto já existente, inventado pelo mecânico alemão Johann Heinrich Goebel (1818-1893), que em 1854 desenvolveu um mecanismo com fibras de bambu e ampolas de vidro transparente. Porém, como não tinha base estrutural para ser usado em escala comercial, acabou sendo utilizado apenas para iluminar uma joalheria em Nova York, nos Estados Unidos, que foi também a primeira cidade a receber uma IP elétrica em 1882. (IWASHITA, 2011)

O químico austríaco Carl Auer von Welsbach, por volta de 1909, revolucionou a lâmpada de Edison, com a introdução do filamento incandescente de metal. Outro passo importante foi dado por William David Coolidge, engenheiro americano, que com seu conhecimento físicoquímico, conseguiu trefilar o tungstênio para utilização na lâmpada incandescente. Os filamentos de tungstênio permitiram que as lâmpadas funcionassem em temperaturas mais elevadas, o que possibilitou uma luz mais branca e mais intensa com o mesmo consumo de energia. 
Com essa nova tecnologia, começavam então a IP alimentada por eletricidade, saindo de cena os lampiões com combustível e os faroleiros que colocavam manualmente lanternas em alguns locais das cidades. Mas este progresso deu-se de forma paulatina, afinal, as lâmpadas instaladas primeiro nos Estados Unidos, em 1879, ainda não eram confiáveis. O antigo e o moderno dividiam a função de iluminar as ruas da cidade.

Em 1882, a primeira cidade do mundo a ter iluminação pública, alimentada por eletricidade gerada por uma termelétrica foi Nova Iorque, mas o Brasil, que em alguns momentos se mostrou atrasado para importar novidades, foi extremamente rápido neste período.

É interessante lembrar que o processo de disseminação da IP foi o grande responsável pela propagação dos sistemas de distribuição de energia que temos hoje para atender as residências, comércio e indústria.

No Brasil colonial, conforme apontado em estudos históricos da Memória da Eletricidade (ELETROBRÁS, 2014), as principais fontes de energia luminosa eram de velas de cera e os candeeiros e lamparinas que queimavam diversos tipos de óleo animal (peixe, baleia, lobo marinho) e vegetal (mamona e coco). As velas de cera eram utilizadas para a iluminação das residências, estabelecimentos comerciais, igrejas e oratórios. Já o óleo de baleia era o combustível preferido para a iluminação das ruas das cidades. Depois da lenha, da água e da tração animal, o óleo de baleia foi o combustível mais importante do período colonial, mas outras fontes de energia também foram utilizadas, como a energia eólica para a navegação e a energia solar para secagem do açúcar, carnes, couros e fumo.

Como apontado por Fróes (2006), em 1794, o serviço de iluminação pública passava a ser subsidiado pelos cofres públicos, iniciativa do vice-rei Conde de Rezende, que mandaria instalar cerca de 100 luminárias a óleo pelos postes da cidade do Rio de Janeiro. O sistema utilizado, muito deficiente para uma cidade que já contava com cerca de quarenta mil habitantes, estabelecia quatro lampiões nas ruas de maior movimento e dois nas demais. A segurança era a maior preocupação e por esse motivo o sistema de iluminação pública estava subordinado à Intendência de Polícia.

A utilização de postes para iluminação pública alimentada a óleo não era uma solução prática, pois havia dificuldade na manutenção. Escravos faziam esse trabalho e estavam sempre sujos de óleo e fuligem por terem que constantemente limpar as luminárias, além de terem que dormir próximo às luminárias para agilizar a limpeza. 
A madeira das árvores foi o principal recurso energético utilizado no Brasil até D. Pedro I proclamar a independência, em 1822. Nessa época, alguns países da Europa já estavam utilizando o gás e o vapor obtido com a queima do carvão mineral para movimentar suas fábricas e iluminar suas cidades. Essas novas fontes de energia térmica, mecânica e luminosa despertaram a curiosidade de alguns empresários brasileiros, como Irineu Evangelista de Sousa, o barão de Mauá, que observou, em 1835 que os barcos a vela e a remo, que faziam o transporte de passageiros pela orla marítima e entre a capital e a cidade de Niterói (RJ), foram substituídos por navios a vapor ingleses. Com seu espírito empreendedor, logo iniciou a construção de embarcações a vapor brasileiras. Equipados com caldeiras, os navios do barão utilizavam o carvão mineral importado da Europa como combustível.

O mesmo barão de Mauá, em 1852, iniciou no Rio de Janeiro a construção de uma fábrica de gás, que também utilizava como combustível o carvão mineral europeu. Dois anos depois, seria inaugurado o sistema de iluminação pública a gás da cidade. Na noite de inauguração, o gás, que atravessava 20 quilômetros de encanamentos de ferro, iluminou algumas poucas ruas do centro. As instalações eram modernas e forneceram luz para a cidade por mais de meio século.

Em 10 de agosto de 1881, as luminárias de Edison se acenderam para iluminar a Exposição Internacional da Eletricidade de 1881, realizada em Paris. Os franceses e muitos turistas estrangeiros que queriam conhecer as grandes inovações do mundo fizeram fila para ter a oportunidade de ligar e desligar uma lâmpada. Era o início de uma nova era.

Conforme Iwashita, em 1883, mais exatamente no dia 24 de julho, em Campos, no Rio de Janeiro, utilizou-se de uma máquina a vapor para iluminar o distrito com 39 lâmpadas, sob o comando de D. Pedro II. Era o início de uma nova era para a iluminação pública aqui no País. Neste mesmo ano, a primeira usina hidrelétrica do País, em Diamantina (MG), começou a gerar energia por meio de uma linha de transmissão de $2 \mathrm{~km}$, que acionava equipamentos utilizados na extração de diamantes. Ainda no estado mineiro, em Juiz de Fora, em 1889, construiu-se a primeira hidrelétrica que não servia apenas a interesses privados. Também conhecida como "Farol do Continente", a hidrelétrica de Marmelos é considerada o marco zero da energia elétrica no Brasil e na América Latina.

Segundo os arquivos da Memória da Eletricidade (ELETROBRÁS, 2014), o Imperador D. Pedro II conhecera a energia elétrica na Filadélfia em 1876 e, encantado com a novidade, autorizou Thomas Alva Edison a trazer para o Brasil os aparelhos que ele havia inventado. 
Assim, em 1879, deu-se a primeira demonstração pública da lâmpada elétrica em terras brasileiras: inaugurou-se na cidade do Rio de Janeiro (RJ) a iluminação elétrica da Estação Central da Estrada de Ferro D. Pedro II (atual Estrada de Ferro Central do Brasil). Dois anos depois, em 1881, a diretoria dos Correios e Telégrafos instalou 16 lâmpadas do mesmo tipo no Campo da Aclamação, atual Praça da República, também no Rio de Janeiro. Em dezembro desse mesmo ano, o espaço da Exposição Industrial no prédio do Ministério da Viação, na atual Praça XV, foi iluminado por sessenta lâmpadas da Edson Electric Co. Em junho de 1883, D. Pedro II inaugurou o primeiro serviço de iluminação pública municipal da América do Sul que contava com energia elétrica, em Campos dos Goitacazes (RJ) (Figura 1). Esse serviço dispôs originalmente de um pequeno motor a vapor, três dínamos e 39 lâmpadas, mas funcionou com algumas interrupções, motivadas por defeitos na rede distribuidora.

Figura 1: Primeiro poste elétrico da cidade de Campos dos Goitacazes, RJ

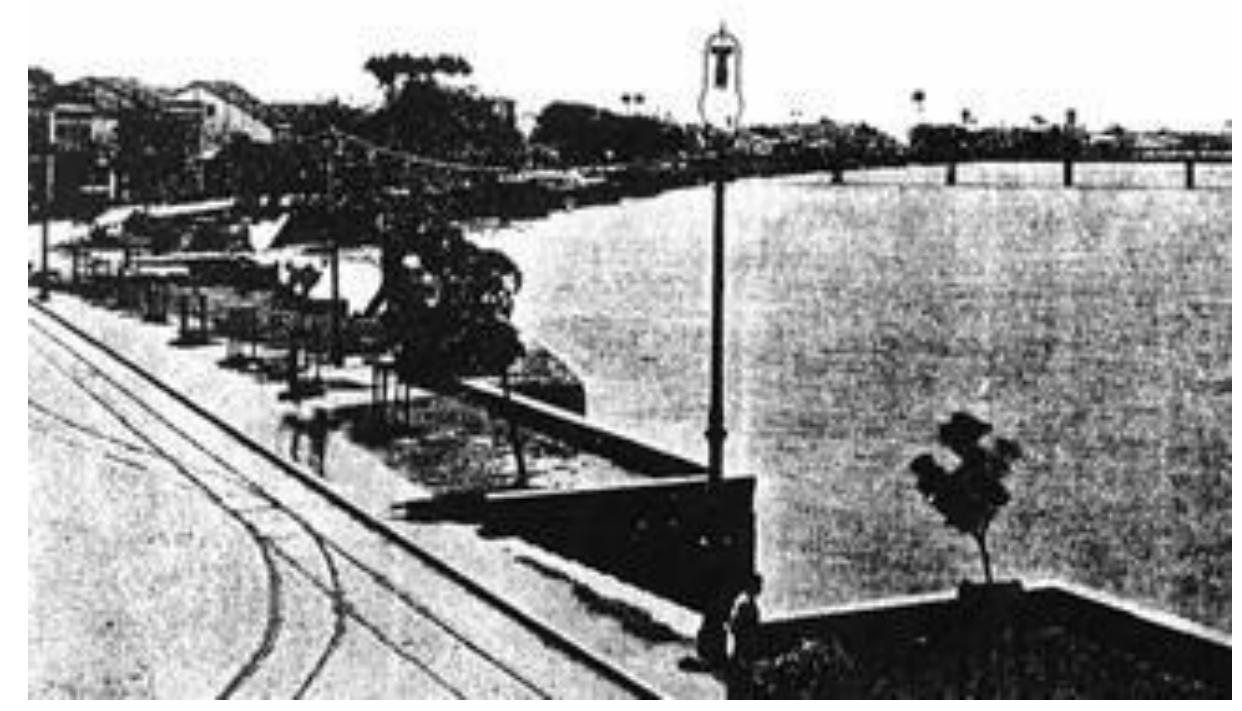

Fonte: Centro de Memória da Eletricidade no Brasil (2014)

Porto Alegre (RS) foi a primeira capital brasileira a ter um serviço público de iluminação elétrica a partir da energia gerada por uma usina térmica da Companhia Fiat Lux, inaugurada em 1887.

No mesmo ano, foi criada, no Rio de Janeiro, a Companhia de Força e Luz, que, devido a sérios problemas financeiros, foi extinta no ano seguinte. Enquanto funcionou, a companhia manteve cerca de cem lâmpadas elétricas para a iluminação de várias ruas do centro da cidade e de algumas poucas residências. 
Empreendimento semelhante foi registrado na cidade de São Paulo (SP), em 1889, depois da instalação da usina termelétrica Água Branca. Destinada inicialmente ao serviço de abastecimento de água, a usina forneceu energia elétrica para iluminação pública e particular no bairro de Água Branca durante 11 anos.

A cidade de Rio Claro, em São Paulo, foi a segunda cidade a ter luz elétrica nas ruas, em razão da presença de uma termoelétrica. Os serviços viabilizados pela energia elétrica se estendiam rapidamente, principalmente no setor têxtil. As primeiras experiências com energia elétrica aconteceram no Rio de Janeiro, mas com o tempo outras cidades brasileiras também passaram a contar com tal benefício. Até 1900, as pequenas usinas instaladas somavam $12 \mathrm{MW}$ de capacidade. Com a chegada do grupo Light do Canadá, o potencial hidrelétrico do país começaria a ser explorado de forma mais intensa. Em 1889 a Light começou a operação de suas primeiras linhas de bondes elétricos na capital paulista, produzindo energia elétrica em uma pequena central a vapor.

O regime de concessão de serviços públicos imperava no Brasil, já que o sistema de administração pública era precário para atender à crescente demanda da sociedade. A Constituição de 1891 não fazia distinção entre a propriedade dos recursos naturais e a posse da terra. As concessões eram geralmente outorgadas pelas prefeituras e o poder concedente em caso de exploração de quedas d'água, era dos governos estaduais. Os primeiros contratos de concessão tinham prazos de até 90 anos, além de garantias financeiras do Estado as concessionárias.

Portanto, a exploração de energia elétrica no Brasil data do início do século XX, quando foram fundadas as primeiras companhias geradoras e distribuidoras, em sua maioria estrangeiras. Muitas dessas empresas celebravam contratos de concessão diretamente com os munícipios. Porém, como o serviço de fornecimento de energia elétrica ganhava progressivamente maior importância, para sua concessão foi atribuída exclusividade federal. Já a prestação do serviço de IP foi atribuída como responsabilidade dos munícipios.

A tecnologia e os equipamentos inicialmente utilizados na IP eram importados. Com o aparecimento da iluminação a gás e a elétrica, o uso do poste passou a ser fundamental nas instalações, pois ele possibilitava realçar a luminária, distribuir melhor os pontos de luz ao longo das praças e ruas, além de servir como instrumento de beleza para as cidades, já que por serem feitos de ferro podiam ser moldados e produzidos de maneira elaborada, como apresentado na Figura 2. A partir de então, iniciou-se a fabricação de equipamentos elétricos para IP no Brasil. 
Figura 2: Poste com luminárias elétricas na Av. Rio Branco (RJ), 1921.

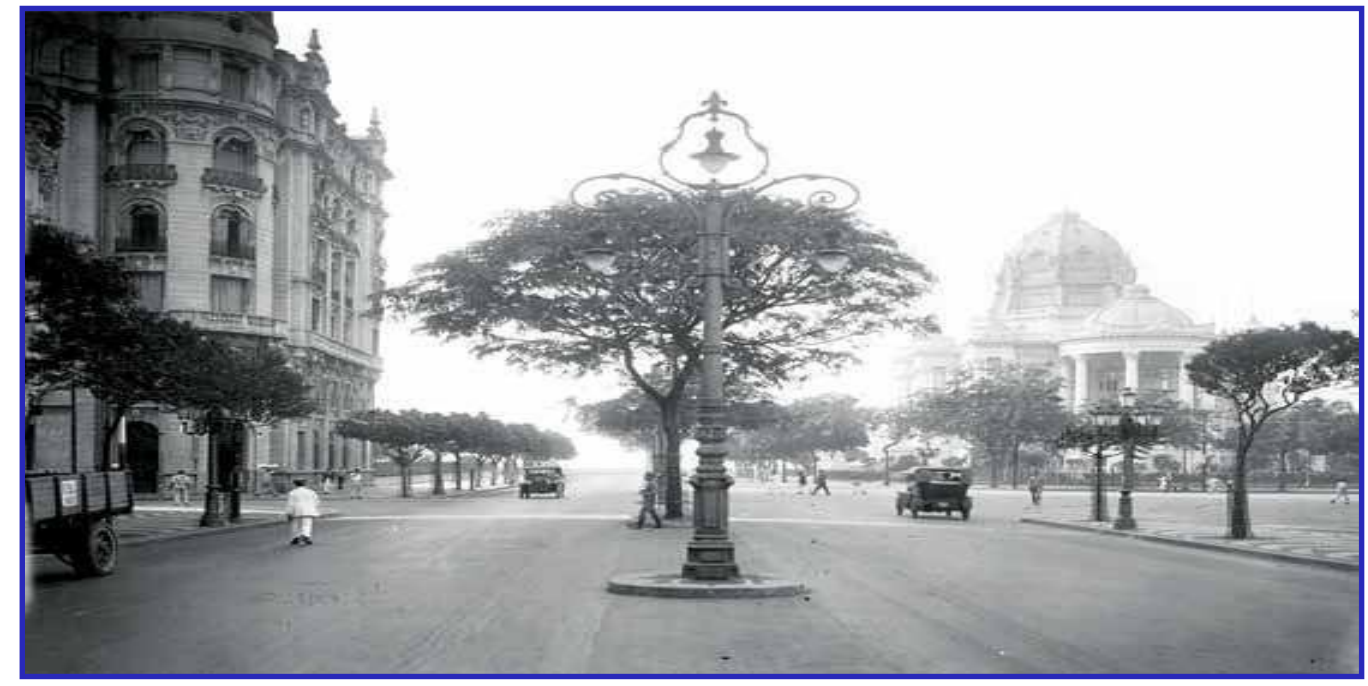

Fonte:Acervo Light (2014)

$\mathrm{Na}$ capital paulista, os poucos pontos de IP existente no final do século XIX eram de responsabilidade da Empresa Paulista de Eletricidade, que foi organizada em 1886, mas iniciou suas atividades apenas em 5 de dezembro de 1888 . Isto porque a população ainda temia que as lâmpadas pudessem trazer problemas à saúde e a empresa teve de enfrentar uma espécie de embate ideológico para conseguir implantar o serviço (GOEKING, 2010).

Hoje São Paulo conta com um dos maiores parques de IP do mundo (Figura 3). Segundo o Departamento de IP de São Paulo - ILUME, órgão estruturado para gerir o acervo de IP do município em recente conclusão de um trabalho de levantamento cadastral, São Paulo conta com uma quantidade de lâmpadas que já ultrapassa 560.000 pontos, distribuídos por $17.000 \mathrm{~km}$ de vias públicas, que corresponde a um consumo mensal de aproximadamente $47 \mathrm{GWh}$. (ILUME. 2013)

Figura 3: Iluminação com lâmpadas de vapor metálico na Av. Paulista, SP

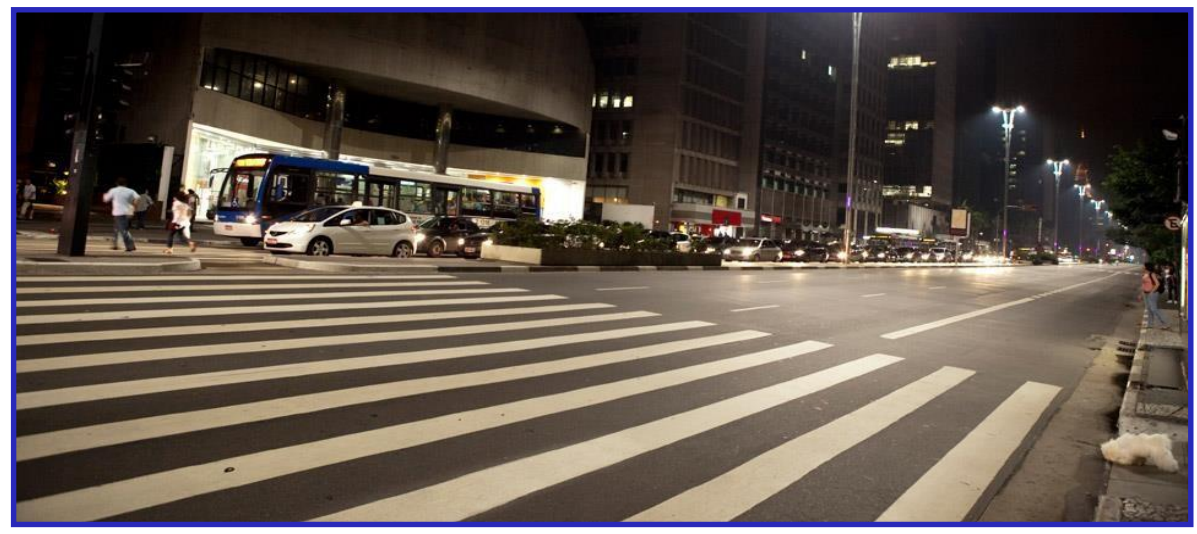

Fonte: Philips (2011) 
Partindo da incandescente, passando pelas lâmpadas a vapor de mercúrio, a vapor de sódio, a multivapores metálicos, pelas lâmpadas de indução e chegando aos LEDs, percebe-se uma transformação radical nos conceitos de iluminação da mesma forma que as transformações da sociedade ditaram mudanças no modo de vida e na organização social.

Como podemos observar na foto da figura 4 (NASA, 2014), a IP está inserida no dia a dia de todas as cidades ao redor do mundo, principalmente nas mais desenvolvidas onde se nota uma maior concentração de luzes.

Figura 4: Foto da Estação Espacial, visão noturna da região da Itália

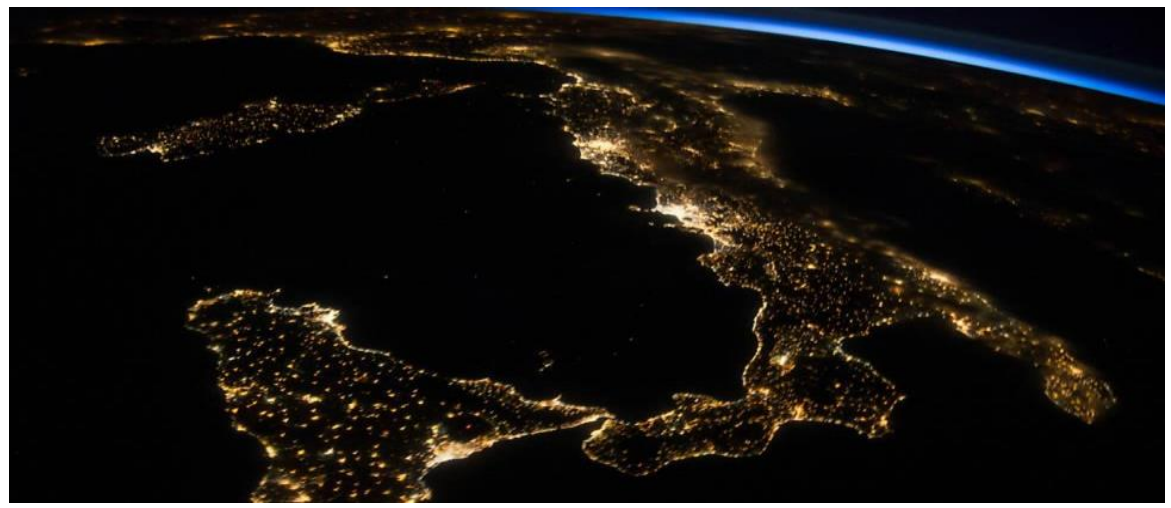

Fonte: NASA (2014)

\section{BASE REGULATÓRIA}

A Constituição Federal brasileira de 1988 estabelece que é responsabilidade dos Municípios organizar e prestar, diretamente ou sob regime de concessão ou permissão, os serviços públicos de interesse local. O Município deve oferecer iluminação artificial aos logradouros públicos, inclusive para lugares que precisam de iluminação permanente no período diurno. A distribuidora de energia elétrica local ou uma empresa especializada podem prestar o serviço de IP mediante contrato específico para tal fim, ficando a pessoa jurídica de direito público responsável pelas despesas decorrentes.

\subsection{Resolução 456/2000}

Em 29/11/2000 a ANEEL publicou a Resolução 456/2000, cujo principal objetivo foi disciplinar o mercado de Energia Elétrica, principalmente a relação entre concessionárias e 
consumidores. Essa Resolução foi um grande avanço do ponto de vista democrático, pois incorporou anseios expressos em Audiências Públicas e de órgão de defesa do consumidor.

A Resolução ANEEL n 456/2000, em seu artigo $2^{\circ}$, inciso XXIV, definiu de iluminação pública como:

Serviço que tem por objetivo prover de luz, ou claridade artificial, os logradouros públicos no período noturno ou nos escurecimentos diurnos ocasionais, inclusive aqueles que necessitam de iluminação permanente no período diurno. (ANEEL, 2000)

A Iluminação Pública, na definição da Resolução, tem a preocupação de atender a todos os ambientes públicos comuns, pois são de fundamental importância às cidades Brasileiras.

Com relação à responsabilidade da Iluminação Pública, a Resolução ANEEL nº . 456/2000, em seus artigos $n^{\circ} 114$ e 115 , define que:

Art. 114. A responsabilidade pelos serviços de elaboração de projeto, implantação, expansão, operação e manutenção das instalações de iluminação pública é de pessoa jurídica de direito público ou por esta delegada mediante concessão ou autorização, podendo a concessionária prestar esses serviços mediante celebração de contrato específico para tal fim, ficando o consumidor responsável pelas despesas decorrentes.

Parágrafo único. Quando o sistema de iluminação pública for de propriedade da concessionária, esta será responsável pela execução e custeio dos respectivos serviços de operação e manutenção.

Art. 115. Nos casos em que o Poder Público necessite acessar o sistema elétrico de distribuição, para a realização de serviços de operação e manutenção das instalações de iluminação pública, deverão ser observados os procedimentos de rede da concessionária local. (ANEEL, 2000)

Neste ponto da Resolução é evidenciado que a responsabilidade da Iluminação Pública é do Poder Público, entretanto pode se delegar esta responsabilidade a terceiros por meio de concessão ou autorização.

\subsection{Resolução 414/2010}

A Resolução ANEEL no 414/2010 de 09 de setembro de 2010 veio com o objetivo de atualizar a Resolução ANEEL n 456/2000, que foi formulada após a realização de audiências 
públicas e consultas públicas, visando receber contribuições de agentes do setor e da sociedade em geral, buscando aperfeiçoar as condições gerais de fornecimento de energia elétrica.

De acordo com a Resolução ANEEL n ${ }^{\circ}$ 414/2010, a responsabilidade pelos serviços de elaboração de projeto, implantação, expansão, operação e manutenção das instalações de IP é de pessoa jurídica de direito público ou por esta delegada mediante concessão ou autorização. Determina ainda que, nos casos onde o sistema de IP estiver registrado como Ativo Imobilizado em Serviço - AIS da distribuidora, esta deve transferir os respectivos ativos à pessoa jurídica de direito público competente. O artigo 218 dessa resolução estabelece os prazos para as distribuidoras comprovarem o envio das propostas de transferência dos ativos de IP para os poderes públicos de sua área de concessão. Dessa forma, os Municípios que ainda não são proprietários do seu parque de IP terão um prazo determinado para se ajustarem. Onde se lê:

A distribuidora deve transferir o sistema de IP registrada como Ativo Imobilizado em Serviço - AIS à pessoa jurídica de direito público competente.

$\S 1^{\circ} \mathrm{A}$ transferência à pessoa jurídica de direito público competente deve ser realizada sem ônus, observados os procedimentos técnicos e contábeis para a transferência estabelecidos em resolução específica.

$\S 2^{\circ}$ Até que as instalações de IP sejam transferidas, devem ser observadas as seguintes condições:

I - o ponto de entrega se situará no bulbo da lâmpada;

II - a distribuidora é responsável apenas pela execução e custeio dos serviços de operação e manutenção; e

III - a tarifa aplicável ao fornecimento de energia elétrica para IP é a tarifa B4b.

$\S 3^{\circ} \mathrm{A}$ distribuidora deve atender às solicitações da pessoa jurídica de direito público competente quanto ao estabelecimento de cronograma para transferência dos ativos, desde que observado o prazo limite de 31 de janeiro de 2014.

$\S 4^{\circ}$ Salvo hipótese prevista no $\S 3^{\circ}$, a distribuidora deve observar os seguintes prazos máximos:

I - até 14 de março de 2011: elaboração de plano de repasse às pessoas jurídicas de direito público competente dos ativos referidos no caput e das minutas dos aditivos aos respectivos contratos de fornecimento de energia elétrica em vigor;

II - até $1^{\text {o }}$ de julho de 2012: encaminhamento da proposta da distribuidora à pessoa jurídica de direito público competente, com as respectivas minutas dos termos contratuais a serem firmados e com relatório detalhando o AIS, por município, e apresentando, se for o caso, o relatório que demonstre e comprove a constituição desses ativos com os Recursos Vinculados à Obrigações Vinculadas ao Serviço Público

(Obrigações Especiais); 
III - até $1^{\circ}$ de março de 2013: encaminhamento à ANEEL do relatório conclusivo do resultado das negociações, por município, e o seu cronograma de implementação;

IV - até 30 de setembro de 2013: encaminhamento à ANEEL do relatório de acompanhamento da transferência de ativos, objeto das negociações, por município;

V - até 31 de janeiro de 2014: conclusão da transferência dos ativos; e

VI - até $1^{\circ}$ de março de 2014: encaminhamento à ANEEL do relatório final da transferência de ativos, por município.

$\S 5^{\circ}$ A partir da transferência dos ativos ou do vencimento do prazo definido no inciso $\mathrm{V}$ do $\S 4^{\circ}$, em cada município, aplica-se integralmente o disposto na Seção $\mathrm{X}$ do Capítulo II, não ensejando quaisquer pleitos compensatórios relacionados ao equilíbrio econômico-financeiro, sem prejuízo das sanções cabíveis caso a transferência não tenha se realizado por motivos de responsabilidade da distribuidora. (ANEEL, 2010)

\subsection{Resolução 479/2012}

Em 3 de abril de 2012, foi publicada a Resolução Normativa ANEEL 479/2012 que altera a Resolução Normativa $n^{\circ}$ 414/2010 de forma atualizada e consolidada, que entre outras alterações, redefine o artigo 21, conforme segue:

Art. 13. Alterar o art. 21 da Resolução Normativa $n^{\circ}$ 414, de 2010, que passa a vigorar com a seguinte redação:

Art. 21. A elaboração de projeto, a implantação, expansão, operação e manutenção das instalações de iluminação pública são de responsabilidade do ente municipal ou de quem tenha recebido deste a delegação para prestar tais serviços.

$\S 1^{\circ}$ A distribuidora pode prestar os serviços descritos no caput mediante celebração de contrato específico para tal fim, ficando a pessoa jurídica de direito público responsável pelas despesas decorrentes.

$\S 2^{\circ}$ A responsabilidade de que trata o caput inclui todos os custos referentes à ampliação de capacidade ou reforma de subestações, alimentadores e linhas já existentes, quando necessárias ao atendimento das instalações de iluminação pública, observado o disposto nos $\S \S 1^{\circ}$ a $4^{\circ}$ do art. 43. "

Também altera, através do Art. 124, a redação do art. 218 da Resolução Normativa n ${ }^{\circ 14}$, de 2010, que passa a vigorar com a seguinte redação:

“Art. 218. A distribuidora deve transferir o sistema de iluminação pública registrado como Ativo Imobilizado em Serviço - AIS à pessoa jurídica de direito público competente.

$\S 1^{\circ} \mathrm{A}$ transferência à pessoa jurídica de direito público competente deve ser realizada sem ônus, observados os procedimentos técnicos e contábeis para a transferência estabelecidos em resolução específica.

$\S 2^{\circ}$ Até que as instalações de iluminação pública sejam transferidas, devem ser observadas as seguintes condições: 
I - o ponto de entrega se situará no bulbo da lâmpada;

II - a distribuidora é responsável apenas pela execução e custeio dos serviços de operação e manutenção; e

III - a tarifa aplicável ao fornecimento de energia elétrica para iluminação pública é a tarifa B4b.

$\S 3^{\circ} \mathrm{A}$ distribuidora deve atender às solicitações da pessoa jurídica de direito público competente quanto ao estabelecimento de cronograma para transferência dos ativos, desde que observado o prazo limite de 31 de janeiro de 2014.

$\S 4^{\circ}$ Salvo hipótese prevista no $\S 3^{\circ}$, a distribuidora deve observar os seguintes prazos máximos:

I - até 14 de março de 2011: elaboração de plano de repasse às pessoas jurídicas de direito público competente dos ativos referidos no caput e das minutas dos aditivos aos respectivos contratos de fornecimento de energia elétrica em vigor;

II - até $1^{\circ}$ de julho de 2012: encaminhamento da proposta da distribuidora à pessoa jurídica de direito público competente, com as respectivas minutas dos termos contratuais a serem firmados e com relatório detalhando o AIS, por município, e apresentando, se for o caso, o relatório que demonstre e comprove a constituição desses ativos com os Recursos Vinculados à Obrigações Vinculadas ao Serviço Público (Obrigações Especiais);

III - até $1^{\circ}$ de março de 2013: encaminhamento à ANEEL do relatório conclusivo do resultado das negociações, por município, e o seu cronograma de implementação;

IV - até 30 de setembro de 2013: encaminhamento à ANEEL do relatório de acompanhamento da transferência de ativos, objeto das negociações, por município;

V - até 31 de janeiro de 2014: conclusão da transferência dos ativos; e

VI - até $1^{\circ}$ de março de 2014: encaminhamento à ANEEL do relatório final da transferência de ativos, por município.

$\S 5^{\circ}$ A partir da transferência dos ativos ou do vencimento do prazo definido no inciso $\mathrm{V}$ do $\S 4^{\circ}$, em cada município, aplica-se integralmente o disposto na Seção X do Capítulo II, não ensejando quaisquer pleitos compensatórios relacionados ao equilíbrio econômico-financeiro, sem prejuízo das sanções cabíveis caso a transferência não tenha se realizado por motivos de responsabilidade da distribuidora." (ANEEL, 2012) 


\subsection{Resolução 480/2012}

Em 3 de abril de 2012, foi publicada as Resoluções ANEEL 480/2012 que estabelece os procedimentos para a transferência sem ônus ao Poder Público Municipal dos ativos de iluminação pública registrados no Ativo Imobilizado das concessionárias de serviços públicos de distribuição de energia, de que trata a Resolução ANEEL n ${ }^{\circ} 414 / 10$, considerando que existem municípios em que o Ativo Imobilizado do sistema de iluminação pública encontra-se registrado sob propriedade da concessionária de serviço público de distribuição de energia local e é necessário regulamentar os procedimentos a serem adotados pelas concessionárias de serviços públicos de distribuição de energia elétrica no processo de transferência do sistema de iluminação pública ao Poder Público Municipal, de que trata a Resolução Normativa ANEEL $\mathrm{n}^{\mathrm{o}} 414$, de 15 de setembro de 2010, e resolve:

Art. $1^{\circ}$ Estabelecer, na forma desta Resolução, os procedimentos técnicos contábeis para a transferência, sem ônus, à pessoa jurídica de direito público competente, das instalações de iluminação pública registradas no Ativo Imobilizado das concessionárias de serviço público de distribuição de energia elétrica.

Parágrafo único. A transferência das instalações de iluminação pública deverá ser efetivada observando-se os procedimentos estabelecidos nesta Resolução e no Manual de Contabilidade do Setor Elétrico, instituído pela Resolução Normativa n ${ }^{\circ} 444$, de 26 de outubro de 2001

Define também os critérios para a rastreabilidade dos ativos de iluminação pública, como segue:

Art. $3^{\circ}$ A Distribuidora comprovará o quantitativo de ativos por município, utilizandose da quantidade de pontos de iluminação pública faturados mensalmente da Pessoa Jurídica de Direito Público, com base nos seus sistemas técnicos georreferenciados, comerciais ou operacionais.

Parágrafo único. A Distribuidora que dispuser de mecanismos que permitam a rastreabilidade contábil dos ativos por municípios, poderá, alternativamente ao disposto no caput, mensurar os ativos de iluminação pública com base nos valores contábeis registrados na Distribuidora por município da área de concessão.

Os critérios contábeis para a transferência dos ativos e responsabilidades, são apontados nos artigos seguintes:

Art. $4^{\circ}$ A Distribuidora deverá identificar nos ativos de iluminação pública constantes do AIS, por município, os valores contábeis, valor da depreciação acumulada e valor residual contábil.

Parágrafo único. A Distribuidora que não dispuser de controle dos ativos de iluminação pública por município, deverá ponderar os respectivos valores de que trata o caput por município, conforme parágrafo único do art. $3^{\circ}$ desta Resolução.

Art. $5^{\circ}$ A movimentação contábil associada à transferência física dos ativos de iluminação pública deverá ser efetuada (conforme simulação em anexo) da seguinte forma: 
a) Baixa do acervo de bens: Contabilizar a baixa do valor contábil e depreciação acumulada dos valores do acervo de Iluminação Pública a ser transferido para o Poder Público.

b) Baixa do saldo das Obrigações Especiais: Contabilizar a baixa do valor das Obrigações Especiais e respectiva amortização - subgrupo 223 - Obrigações Vinculadas às Concessões de Serviço Público de Energia Elétrica, correspondente aos valores do acervo de Iluminação Pública mencionado, resultando em uma operação sem impactos econômicos ou financeiros para as partes.

Art. $6^{\circ}$ A Distribuidora deverá dar ciência prévia ao Poder Público Municipal ou Distrital quanto aos critérios e procedimentos estabelecidos nesta Resolução.

Art. $7^{\circ}$ A Distribuidora deverá manter disponível pelo prazo de 5 anos os documentos que compõem cada processo de transferência de ativos de iluminação pública por município da área de concessão, para fins de fiscalização da ANEEL

\subsection{Resolução 587/2013}

No âmbito da Audiência ANEEL $n^{\circ}$ 107/2013, as prefeituras apresentaram suas preocupações quanto à prorrogação do prazo em questão sob o argumento de que as dificuldades com o processo de transferência não se resumiriam aos pequenos municípios, destacando os seguintes problemas: (i) o alto índice de renovação de prefeitos verificada no último pleito municipal, ocasionando interrupção da interlocução entre prefeituras e distribuidoras; (ii) a necessidade de ajustes às contribuições de iluminação pública ou mesmo sua criação; dentre outros. Outra preocupação levantada pelas prefeituras diz respeito ao estado de conservação dos ativos de iluminação pública a serem transferidos para os Municípios.

Para essa questão específica, a Resolução ANEEL n 587/2013, de 10 de dezembro de 2013, que altera o artigo 218 da Resolução 414/2010, e determinou que as distribuidoras deverão encaminhar, a cada Município, termo de responsabilidade atestando que as condições dos ativos se encontram dentro dos padrões de qualidade previstos nas normas técnicas, conforme abaixo:

Art. $1^{\circ}$ Alterar a redação dos $\S \S 3^{\circ}$ e $4^{\circ}$ e incluir os $\S \S 6^{\circ}$ e $7^{\circ}$ no art. 218 da Resolução Normativa $\mathrm{n}^{\circ} 414$, de 2010, que passam a vigorar com a seguinte redação:

Art. 218.

$\$ 3^{\circ} \mathrm{A}$ distribuidora deve atender às solicitações da pessoa jurídica de direito público competente quanto ao estabelecimento de cronograma para transferência dos ativos, desde que observado o prazo limite de 31 de dezembro de 2014. 
IV - até $1^{\circ}$ de agosto de 2014: encaminhamento à ANEEL do relatório de acompanhamento da transferência de ativos, objeto das negociações, por município;

V - 31 de dezembro de 2014: conclusão da transferência dos ativos; e

VI - até $1^{\circ}$ de março de 2015: encaminhamento à ANEEL do relatório final de transferência dos ativos, por município.

$\S 6^{\circ}$ A distribuidora deve encaminhar a ANEEL, como parte da solicitação de anuência de transferência dos ativos de iluminação pública, por município, o termo de responsabilidade em que declara que o sistema de iluminação pública está em condições de operação e em conformidade com as normas e padrões disponibilizados pela distribuidora e pelos órgãos oficiais competentes, observado também o disposto no Contrato de Fornecimento de Energia Elétrica acordado entre a distribuidora e o Poder Público Municipal, conforme Anexo da Resolução Normativa nº 587, de 10 de dezembro de 2013.

$\S 7^{\circ} \mathrm{A}$ distribuidora deve atender às solicitações da pessoa jurídica de direito público competente acerca da entrega dos dados sobre o sistema de iluminação pública.

Art. 218

$\S 3^{\circ} \mathrm{A}$ distribuidora deve atender às solicitações da pessoa jurídica de direito público competente quanto ao estabelecimento de cronograma para transferência dos ativos, desde que observado o prazo limite de 31 de dezembro de 2014.

$\S 4^{\circ}$

IV - até $1^{\circ}$ de agosto de 2014: encaminhamento à ANEEL do relatório de acompanhamento da transferência de ativos, objeto das negociações, por município;

V - 31 de dezembro de 2014: conclusão da transferência dos ativos; e

VI - até $1^{\circ}$ de março de 2015: encaminhamento à ANEEL do relatório final de transferência dos ativos, por município.

$\S 6^{\circ}$ A distribuidora deve encaminhar a ANEEL, como parte da solicitação de anuência de transferência dos ativos de IP, por município, o termo de responsabilidade em que declara que o sistema de IP está em condições de operação e em conformidade com as normas e padrões disponibilizados pela distribuidora e pelos órgãos oficiais competentes, observado também o disposto no Contrato de Fornecimento de Energia Elétrica acordado entre a distribuidora e o Poder Público Municipal, conforme Anexo VIII.

$\S 7^{\circ} \mathrm{A}$ distribuidora deve atender às solicitações da pessoa jurídica de direito público competente acerca da entrega dos dados sobre o sistema de IP.

\subsection{COSIP - Contribuição para o custeio do serviço de IP}

Com a promulgação da Emenda Constitucional no 39 de 19 de dezembro de 2012, a 
Constituição Federal passou a vigorar com o acréscimo do artigo 149-A, que determina que os Municípios e o Distrito Federal poderão instituir contribuição, na forma das respectivas leis, para o custeio do serviço de IP, conhecida como CIP ou COSIP. Além disso, também é facultada a cobrança da contribuição, na fatura de consumo de energia elétrica.

Antes da edição desta Emenda Constitucional, vários Municípios haviam criado uma taxa de IP para custear as despesas da disponibilização do serviço de IP. Isso gerou um grande descontentamento por parte dos contribuintes, que tiveram que arcar com mais um tributo, adicionado a uma carga tributária bastante elevada. Surgiram diversas ações judiciais questionando a legalidade e constitucionalidade do tributo e o Supremo Tribunal Federal firmou entendimento no sentido da inconstitucionalidade material da exação, já que não teria natureza jurídica de taxa, não sendo possível individualizar o contribuinte, faltando, assim, o requisito da divisibilidade do serviço público.

Em consequência disso, os Municípios tiveram uma perda de arrecadação, resultando em um maior endividamento com as concessionárias de energia elétrica.

Houve então uma pressão, por parte dos prefeitos, no Congresso Nacional para criação de uma exação que substituísse a taxa de IP, tendo em vista que somente o Poder Constituinte teria competência para ampliar a carga tributária.

A partir daí, foi permitido aos Municípios criar as leis que estabelecem os critérios de cobrança e isenção aos contribuintes. $O$ tributo pode ser cobrado através das faturas de energia das Concessionárias Distribuidoras de Energia, baseado em contrato a ser assinado entre Município e Concessionária, conforme previsto em lei. Anualmente, ou de acordo com a necessidade, são feitos decretos ou leis com reajustes dos tributos ou modificações.

Existem três formas de cobrança mais utilizadas no Brasil:

- Tabela com valores fixos, baseados em uma porcentagem do consumo de energia elétrica de cada cidadão;

- Com base na tarifa básica de IP, valor fixo;

- Por tipo de medidor ou por unidades fiscais criadas pelos Municípios.

Existem Leis que isentam clientes rurais, outras que isentam classes e faixas de consumo como clientes residenciais com consumo inferior a $30 \mathrm{kWh}$, e ainda aquelas Leis que isentam contribuintes sem iluminação nas proximidades de sua residência. Qualquer alternativa depende 
da aprovação na Câmara de Vereadores do Município. Na maioria dos casos os clientes de baixa renda são isentos da cobrança.

\subsection{Tarifas de IP}

Na Resolução ANEEL n ${ }^{\circ}$. 456/2000 estavam previstos dois tipos de tarifas, uma quando o poder público é responsável pela manutenção e outra quando delega ao concessionário. A redação da lei é seguinte:

Art. 116. As tarifas aplicáveis aos fornecimentos de energia elétrica para iluminação pública serão estruturadas de acordo com a localização do ponto de entrega, a saber:

I - Tarifa B4a: aplicável quando o Poder Público for o proprietário do sistema de iluminação pública; e

II - Tarifa B4b: aplicável quando o sistema de iluminação pública for de propriedade da concessionária.

Quanto ao cálculo do consumo da IP, de acordo com a Resolução ANEEL n 456/2000, se dava da seguinte forma:

Para fins de faturamento de energia elétrica destinada à iluminação pública ou iluminação de vias internas de condomínios fechados, será de 360 (trezentos e sessenta) o número de horas a ser considerado como tempo de consumo mensal, ressalvado o caso de logradouros públicos que necessitem de iluminação permanente, em que o tempo será de 24 (vinte e quatro) horas por dia do período de fornecimento. (ANEEL, 2000)

Sobre o número 360/mensal apesar do mesmo não estar detalhado é importante entender que o raciocínio é mês de 30 dias com consumo de 12 horas.

No momento atual, a modalidade tarifária praticada pelas Concessionárias, para o faturamento do consumo da IP, está definida na Resolução ANEEL no 414/2010, de 09 de setembro de 2010, que veio com o objetivo de atualizar a Resolução ANEEL nº 456/2000.

Quanto aos tipos de tarifas a resolução em questão define em seu artigo 24, §2, que a "a tarifa aplicável ao fornecimento de energia elétrica para IP é a Tarifa B4a".

Com a publicação da Resolução 414/2010, observou-se a existência de apenas uma opção de tarifa, a B4a, que é aquela que não incorpora o custo da manutenção da prestação do serviço pela concessionária. Com a modificação da Resolução 456, (Resolução ANEEL 456, 2000) houve a exclusão da tarifa B4b, cerca de 9,5\% superior a B4a, aplicável quando o sistema de IP 
fosse de propriedade da concessionária. Agora a concessionária poderá ser a prestadora do serviço de manutenção, caso seja a ganhadora do certame licitatório.

Para fins de faturamento da energia elétrica destinada a IP ou a iluminação de vias internas de condomínios, o tempo a ser considerado para consumo diário deve ser de 11 (onze) horas e 52 (cinquenta e dois) minutos, ressalvado o caso de logradouros que necessitem de iluminação permanente, em que o tempo é de 24 (vinte e quatro) horas por dia do período de fornecimento. Esses números são baseados na média do tempo que as lâmpadas de IP ficam acesas nas cidades brasileiras, conforme orientações do Observatório Nacional (ON), instituto de pesquisa vinculado ao Ministério da Ciência, Tecnologia e Inovação (MCTI). 


\section{DESCRIÇÃO DO SISTEMA DE IP}

Segundo apurado na literatura e nas soluções encontradas no mercado, o padrão estrutural do sistema de IP baseia-se em um sistema de fornecimento de energia elétrica, um sistema de sustentação dos dispositivos de IP, um sistema de acionamento e um sistema de geração de luz.

\subsection{Sistema de fornecimento de energia}

Os diversos arranjos de sistemas de fornecimento de energia elétrica destinado a IP atualmente utilizados no Brasil se diferenciam basicamente pelas características de fornecimento que são adotadas pelas concessionárias ou permissionárias de distribuição de energia elétrica. De uma forma geral o fornecimento de energia elétrica é em baixa tensão, conforme demonstrado na Figura 5, ou seja, em tensão entre $110 \mathrm{~V}$ a $230 \mathrm{~V}$ e pode ser aéreo ou subterrâneo. Existem alguns lugares em que, apesar dos transformadores pertencerem às prefeituras, como na cidade de São Paulo, o fornecimento, ou melhor, a entrega de energia sempre é em baixa tensão.

Figura 5: Esquema de ligação elétrica do sistema de IP

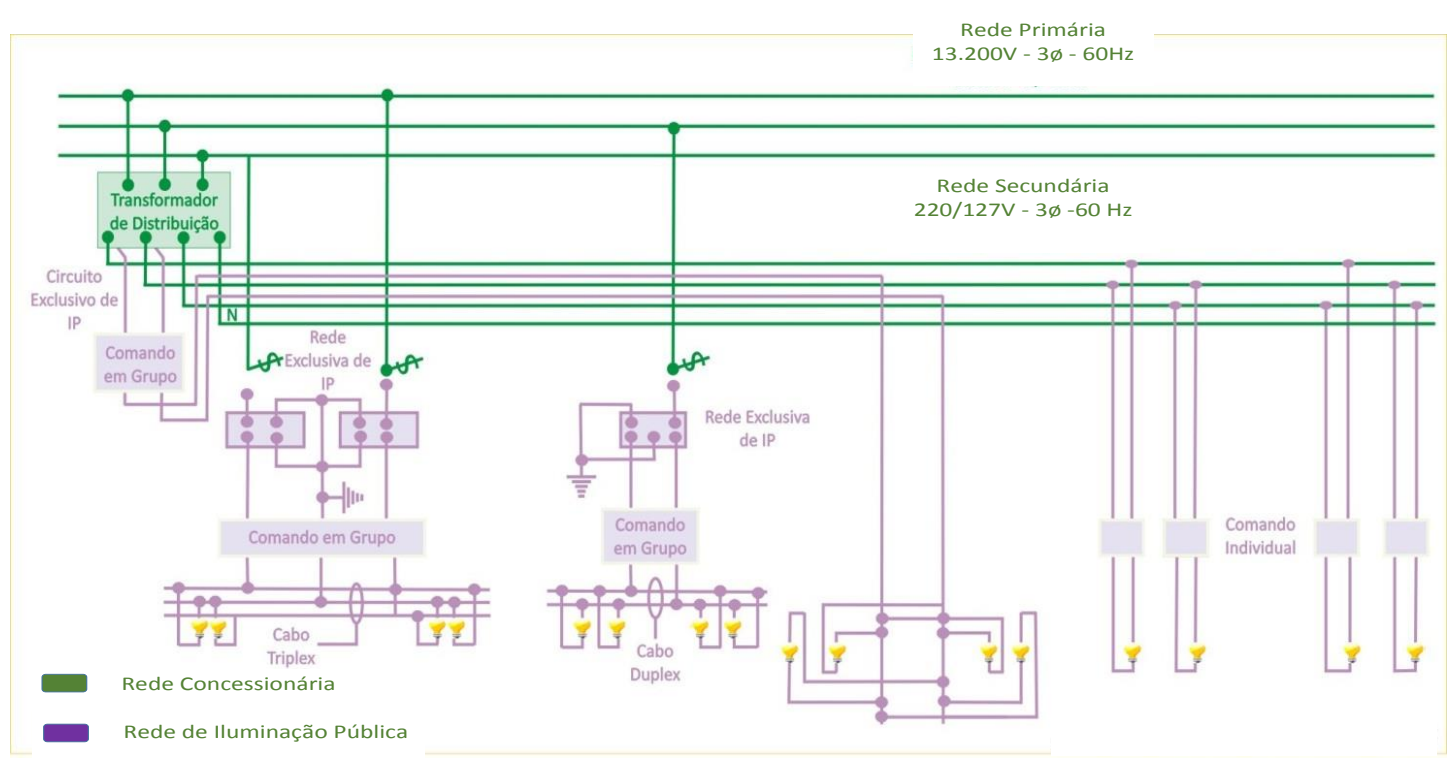

Fonte: Autor, 2014.

A alimentação elétrica pode ser em média tensão, quando a Concessionária leva energia na faixa de $15 \mathrm{kV}$, até os transformadores de propriedade da municipalidade, destinados a alimentar a rede de IP (sistema utilizado no Município de Prefeitura de São Paulo), ou em baixa 
tensão, quando o ponto de entrega de energia é definido como sendo no circuito secundário da Concessionária local.

Existem ainda exceções como os casos de iluminação de destaques, alimentadas a partir do quadro de força de edifícios, em alguns casos com medidores.

\subsection{Sistema de Acionamento}

Existem basicamente dois tipos de acionamento de sistemas de IP, o acionamento em grupo e o acionamento individual. Como é sugerido pelos nomes, no acionamento em grupo, um grupo de lâmpadas são acesas simultaneamente, enquanto que no acionamento individual o acendimento é feito em cada uma das lâmpadas.

No acionamento em grupo, cada circuito é associado a um conjunto de equipamentos de proteção e comando, constituído pelo relé fotoelétrico e uma chave magnética na condição normalmente fechada (NF). Nesta configuração, o contato do relé se abre quando da presença da luz natural, desligando a chave magnética e o grupo de lâmpadas do circuito. No caso de falha do relé o seu contato permanece fechado e as lâmpadas mantidas acesas continuamente por medida de segurança viária e dos pedestres no período noturno.

Este conjunto normalmente está instalado no mesmo poste da estação transformadora ou em um poste próprio, próximo ao ponto de derivação, no caso das redes subterrâneas.

No acionamento individual, as unidades estão ligadas diretamente à rede da Concessionária, através de um relé fotoelétrico.

Qualquer sistema de acionamento deve obedecer a uma rotina pré-estabelecida de período de operação do sistema de IP, pois além do óbvio funcionamento das unidades de iluminação apenas no período noturno, há os conjuntos de unidades instaladas em túneis que tanto operam no período diurno (iluminação diurna) ou em período integral (iluminação diuturna). 


\subsection{Postes e Braços}

Os postes e braços de sustentação da luminária, figura 6, tem importância fundamental no sistema de IP, pois é através dele que a luminária fica posicionada em condições favoráveis para uma adequada dispersão do fluxo luminoso em uma determinada área. Geralmente, tanto o tamanho do poste como do braço está diretamente ligado à largura e utilização das ruas e avenidas, considerando a abrangência do que se deseja iluminar.

Figura 6: Exemplos de poste e braço de IP
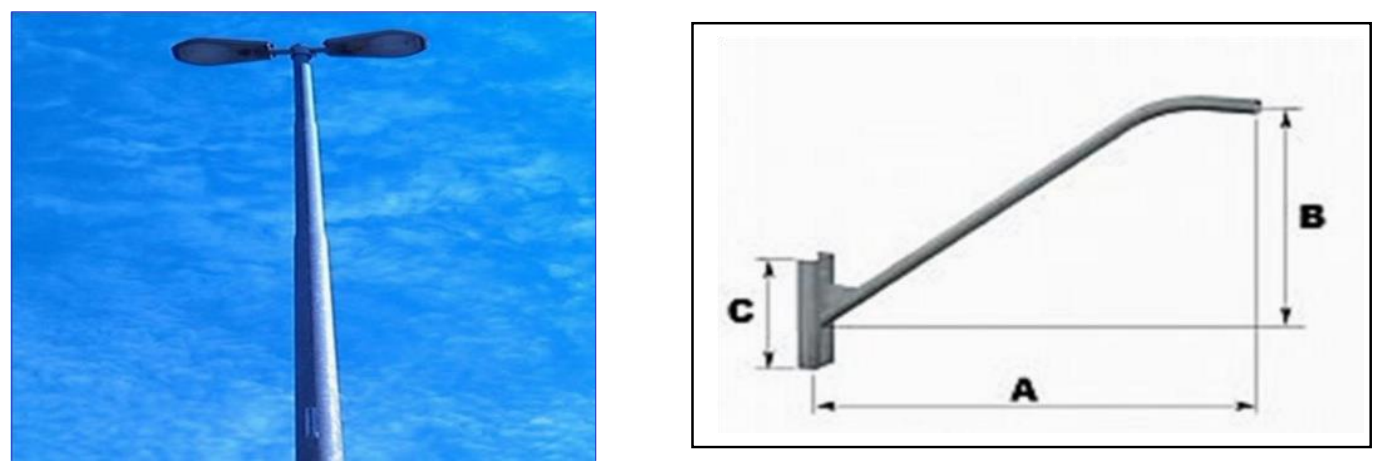

Fonte: Autor, 2014

\subsection{Luminárias}

Um dos principais componentes da IP é sem dúvida a luminária (Figura 7), que tem como principal função direcionar a maior quantidade possível do fluxo luminoso emitido pelas lâmpadas para as áreas de interesse, reduzindo consequentemente a poluição luminosa causada pela dispersão de luminosidade, que poderia causar até ofuscamento aos motoristas que passam pelo local. Ainda existe uma grande quantidade de luminárias que têm um conjunto óptico razoável, porém são abertas, deixando as lâmpadas expostas a choques térmicos, incidência de insetos, vandalismo, etc., reduzindo sua vida útil. Com a evolução do projeto das luminárias, foram desenvolvidos equipamentos fechados em materiais poliméricos ou vidro, que além de uma melhor dispersão luminosa, permitem obter ótimos resultados devido à proximidade dos equipamentos auxiliares como reator e ignitor. Devido a sua presença em diversos locais da área territorial dos municípios, as luminárias também estão utilizadas para acomodar componentes de comunicação com os Centros de Controle de IP, que se dá através de modificações implementadas no relé fotoelétrico, que passa a ser um dispositivo de monitoramento e controle do sistema luminoso. A designação "controle" pode ser entendida 
como é um termo geral para uma ampla gama de metodologias, protocolos e dispositivos para operar equipamentos de iluminação, especialmente para tecnologias mais flexíveis como a LED. As formas mais simples de controle são "ON/OFF" e dimerização. Um protocolo de comunicação é simplesmente um conjunto padrão de regras para o envio de sinais e informações ao longo de um canal de comunicação (WEINERT, 2010).

\section{Figura 7: Exemplo de luminária de IP}

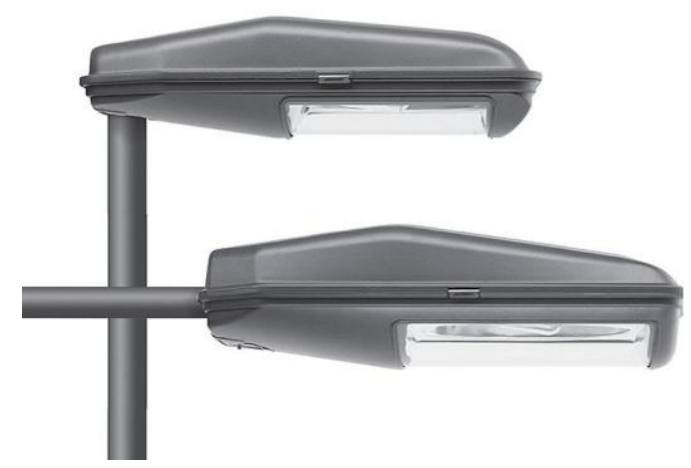

Fonte: Schréder, 2014.

\subsection{Lâmpadas}

É evidente que todos os elementos discutidos até o momento são fundamentais para o funcionamento da rede de IP, mas a "lâmpada" se destaca entre os componentes do conjunto de IP, tendo em vista que é a fonte de luz e também o item de referência considerado na medição do consumo de energia.

A quantidade total de lâmpadas instaladas é indicada na fatura de energia das concessionárias. Devido à variedade de opções promovidas pela evolução da tecnologia, existem diversos modelos instalados, porém observa-se uma predominância das lâmpadas de vapor de mercúrio ou de sódio, como ilustrado na figura 8. Em quantidades muito menores há outros tipos de lâmpadas, como as fluorescentes presentes em alguns túneis e sob pontes e viadutos, as de multivapores metálicos empregadas nos locais onde a qualidade de reprodução de cores é necessária, as de indução eletromagnética utilizadas em locais de difícil acesso e outras lâmpadas especiais, principalmente as voltadas a iluminação de destaque. 
Figura 8: Exemplos de lâmpadas de IP
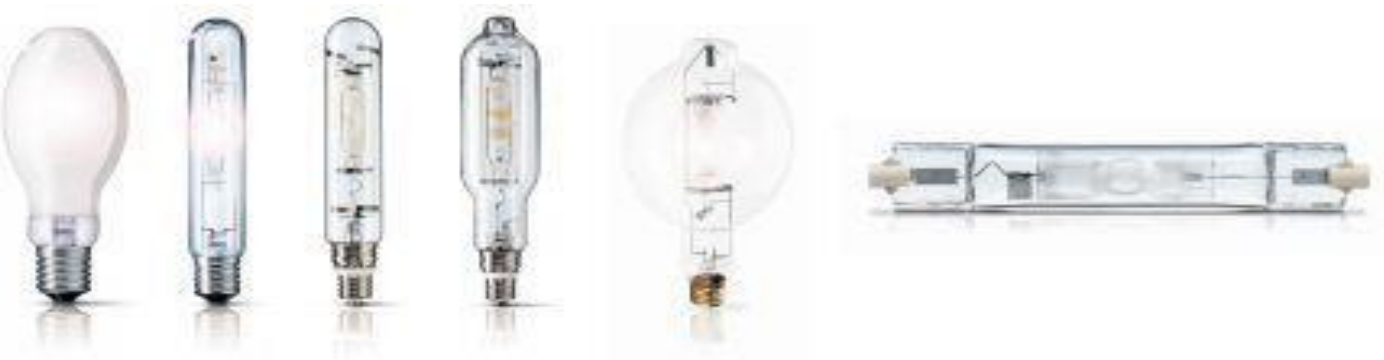

Fonte: Philips, 2013

Quando se trata de lâmpadas de descarga, o acionamento e continuidade de funcionamento das lâmpadas em si dependem ainda do funcionamento dos equipamentos auxiliares formado pelo conjunto reator, capacitor e ignitor, adequados a cada tipo e potência de lâmpada, ilustrados na figura 9.

Figura 9: Exemplo de chave magnética, caixa de proteção e relé fotoelétrico.

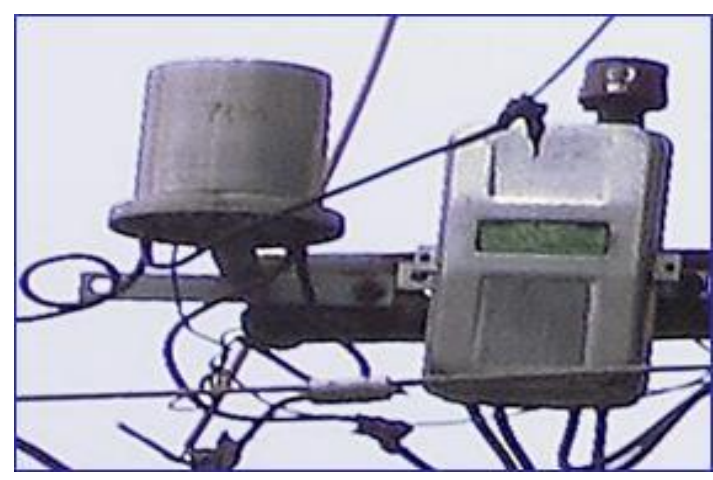

Fonte: Autor, 2014

Já nas luminárias que utilizam tecnologia LED, o acionamento e continuidade de funcionamento dependem do "driver", conjuntos de dispositivos eletrônicos necessários ao seu funcionamento.

\subsection{Unidade de IP}

Unidade de IP é o nome dado ao conjunto completo formado pelo poste, elementos de sustentação, braço, luminárias, lâmpadas e equipamentos auxiliares indispensáveis à sua operação, identificada principalmente pela origem de alimentação. A seguir é apresentado um resumo das famílias de tipos de unidades presentes na rede de IP: 
- Unidade Aérea

o Seu sistema de alimentação de energia se dá através de condutores aéreos.

Normalmente são instaladas em postes de concreto das concessionárias de energia elétrica.

- Unidade Subterrânea

o Seu sistema de alimentação de energia se dá através de condutores subterrâneos, provenientes de tubulações enterradas ou fixadas em estruturas como pontes, viadutos, monumentos, etc.

- Unidade Ornamental

- Seu sistema de alimentação de energia é similar ao sistema anterior, porém os postes e luminárias tem características ornamentais, com intuito de embelezamento da área onde estão instalados.

- Unidades Especiais

o Como o nome já diz, são unidades desenvolvidas especificamente para situações especiais, como obras de arte, obeliscos, etc., como exemplo da figura 10.

Figura 10: Exemplo de iluminação especial. Monumento às Bandeiras (SP)

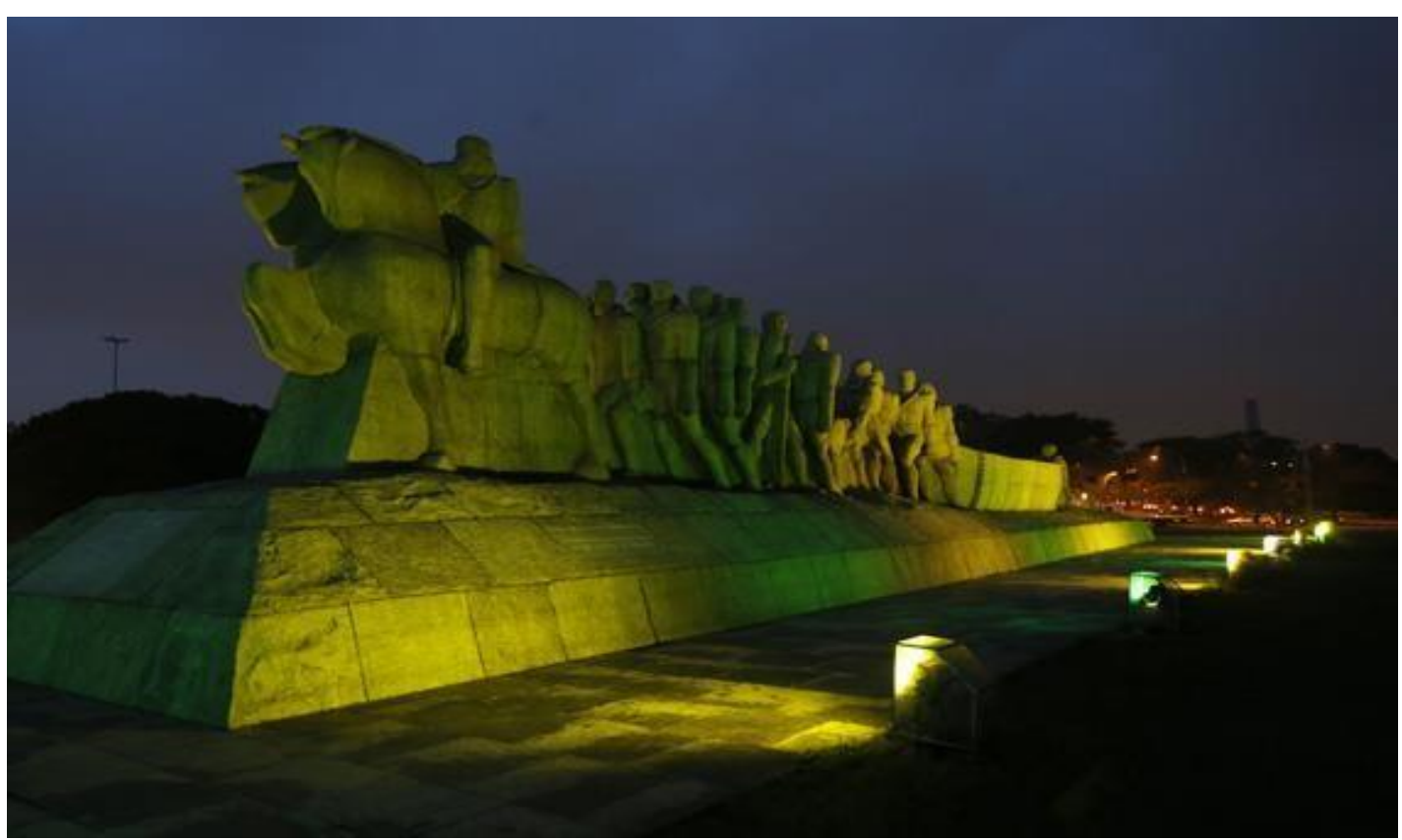

Fonte: Prefeitura de São Paulo, 2013. 


\section{CONTEXTUALIZAÇÃO DO PROBLEMA}

De acordo com a NBR 5101(2012), a IP tem como principal objetivo proporcionar visibilidade para a segurança do tráfego de veículos e pedestres, de forma rápida, precisa e confortável.

O serviço de IP, apesar da sua importância para a população, não tem requisitos de qualidade do fornecimento do mesmo modo que existe no serviço de distribuição de energia elétrica.

O requisito "qualidade no serviço de fornecimento de energia", que garantem índices mínimos de desempenho técnico, vem sendo perseguido pelas Agências Reguladoras, mesmo antes da sua criação nos anos 90, quando as regras eram definidas pelo DNAEE - Departamento Nacional de Águas e Energia Elétrica. Já naquela época, se pensava na questão da qualidade, porém muito voltada para a indústria que estava em pleno avanço no Brasil dos anos 60. Com a criação da ANEEL - Agencia Nacional de Energia Elétrica, houve uma mudança de visão quanto ao produto "energia elétrica" que estava sendo entregue aos consumidores, sem distinção de classes (residencial comercial ou industrial). Com o processo de privatização das Concessionárias de Energia Elétrica, houve uma constante cobrança junto aos Concessionários de Distribuição para que a qualidade não fosse deixada de lado em prol das garantias de retornos financeiros para seus acionistas.

A IP tem impacto direto sobre assuntos primordiais para a população como segurança, educação e lazer, em períodos noturnos, porém as prefeituras não contam com uma cobrança efetiva de um organismo independente que possa fazer o papel de uma Agencia Reguladora que defina um índice de qualidade específico para IP.

Sem regras de qualidade de fornecimento específicas a transferência total dos acervos de IP para as prefeituras, pode piorar o cenário atual, já que estamos tratando de um ente público que, por enquanto, não tem, em sua essência, familiaridade com o objeto dessa transferência, ou seja, o cliente final pode vir a sofrer consequências prejudiciais com essa transferência.

Como reforça Pinheiro (2012), o nível ideal de qualidade dos serviços sempre ocorrerá quando a vontade marginal do consumidor de pagar for igual ao custo marginal da distribuidora para melhorar a qualidade do serviço. O estágio de qualidade do produto e do serviço de distribuição de energia alcançado pelas Concessionárias de Distribuição está extremamente 
voltado para a satisfação do cliente final no que diz respeito ao fornecimento de energia elétrica às suas unidades consumidoras, para o qual as Agências Reguladoras têm foco específico, portanto existe muito menos ênfase na qualidade dos serviços voltados para o assunto em discussão, a IP, já que a percepção do cliente final acaba não sendo tão enfática como no caso do fornecimento de energia a sua propriedade. A baixa qualidade da IP constantemente é assunto dos meios de comunicação que refletem o descontentamento de boa parte da população com o serviço e a qualidade da IP principalmente nas grandes metrópoles, porém a responsabilidade pela sua regularização fica dúbia, tanto pode ser da Concessionária quanto da Prefeitura, dependendo da propriedade do ativo.

Essa baixa qualidade da IP, deve-se principalmente à manutenção ineficiente e ao fato da eficiência energética das luminárias existentes nas vias públicas, em sua grande maioria, estarem obsoletas e discrepantes dos valores estabelecidos nos projetos originais que permitiu sua instalação, considerando evidentemente que os materiais empregados, principalmente as luminárias, reatores e lâmpadas, foram objetos de estudos técnicos adequados para a época em que foram projetados, pois tanto os fabricantes quanto Concessionárias responsáveis, no momento da compra, costumam fazer testes de qualidade e conformidade que certificam os materiais adquiridos.

A NBR 5101 (2012) recomenda que sejam seguidos os bons preceitos de manutenção, como:

a) Operação da fonte de luz, nos valores nominais de corrente e tensão;

b) Substituição das lâmpadas depreciadas, em períodos regulares;

c) Limpeza periódica das luminárias.

O objetivo é manter os valores recomendados de iluminância, apesar do fator de manutenção das luminárias variarem de acordo com as condições locais e densidade de tráfego. Para isso devem ser adotados esquemas de manutenção que sejam pelo menos iguais aos assumidos no projeto de instalação da iluminação, com a realização de manutenção quando a iluminância média atingir $70 \%$ do valor inicial.

No momento do projeto, costuma-se especificar a eficiência total da luminária em unidades de Lúmen/Watt, sendo o lúmen, cujo símbolo é "lm", a unidade do fluxo luminoso emitido pela luminária e o "Watt, cujo símbolo é "W", a potência elétrica consumida pela luminária. Procurase, então, maximizar esta razão para obter a melhor eficiência energética do conjunto luminoso, 
considerando inclusive o tempo previsto por cada fabricante para a estabilização dos resultados esperados. É comum que, ao longo do ciclo de vida dos equipamentos, ocorrerem depreciações diferentes em cada um dos materiais que compõem o conjunto de IP, que denigrem o resultado ótimo previsto em projeto, razão pela qual é importante uma rotina de manutenção preventiva ${ }^{2}$ que mantenha os índices técnicos dentro de patamares aceitáveis, independente da tecnologia empregada.

Na maioria das vezes, devido à falta de uma manutenção preventiva adequada, tem-se um grande volume de manutenção corretiva $^{3}$, onde é substituído apenas o material e/ou equipamento supostamente defeituoso. As constantes manutenções corretivas, principalmente em lâmpadas, sinalizam que a causa do problema pode ser originada por outro material que compõe o conjunto, como por exemplo, os reatores, as conexões malfeitas, etc. Em suma, quando não se faz um estudo adequado da causa de um problema, gera-se um efeito em cadeia que pode levar a um desgaste acelerado dos demais equipamentos que, por sua vez, depreciam o conjunto de IP (luminária, lâmpada, reator e ignitor).

Segundo Santos (2011), o fator de manutenção de uma instalação poderá afetar significativamente a potência da fonte de luz a instalar, bem como o número de luminárias necessárias para alcançar os valores de iluminância/luminância especificados e depende de dois fatores de depreciação: o referente às luminárias e o referente ao fluxo luminoso emitido pelas lâmpadas.

Para se definir o fator de manutenção que o conjunto de IP deverá ser submetido (Gráfico 2), deve-se seguir a seguinte fórmula: FM = FMLL x FSL x FML, onde FM é o fator de manutenção, FMLL é o fator de manutenção da luminosidade da lâmpada, FSL é o fator de sobrevivência da lâmpada e FML é o fator de manutenção da luminária.

\footnotetext{
2 MANUTENÇÃO PREVENTIVA: Segundo a Norma NBR 5462 (1994), é a manutenção efetuada em intervalos predeterminados, ou de acordo com critérios prescritos, destinada a reduzir a probabilidade de falha ou a degradação do funcionamento de um item.

${ }^{3}$ MANUTENÇÃO CORRETIVA: Segundo a Norma NBR 5462 (1994), manutenção corretiva é a manutenção efetuada após a ocorrência de uma pane, destinada a recolocar um item em condições de executar uma função requerida.
} 
Gráfico 2: Representação do fator de manutenção - FM

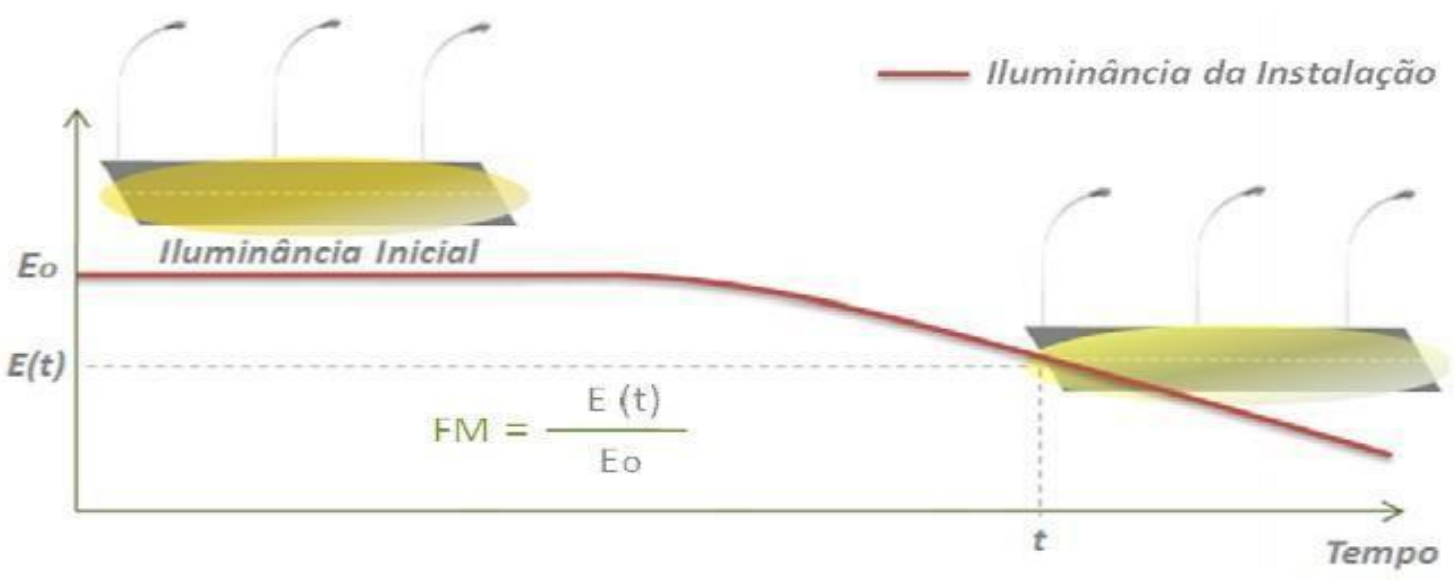

Fonte: Santos (2011).

Segundo Campos (2014), o projeto da luminária deve permitir fácil acesso ao bloco óptico permitindo assim a substituição de lâmpadas sem o comprometimento do seu sistema de selagem, da mesma forma ter o acesso ao compartimento dos equipamentos auxiliares facilitado. Em ambas as situações sem comprometer o Grau de Proteção. O mesmo se aplica a luminárias com tecnologia LED onde o ideal é contar com blocos ópticos selados passíveis de melhorias em função do avanço da tecnologia LED e compartimentos protegidos para abrigarem os equipamentos de acionamento e funcionamento, e eventuais sistemas de gerenciamento (SCHRÉDER, 2009). A tecnologia LED é sem dúvida um dos principais avanços na IP, desde o advento das lâmpadas de descarga, diversos estudos já demonstram que a sua utilização pode trazer grande economia na conta de energia, repercutindo significativamente em economia aos cofres municipais, porém, a que se ter cautela, pois ainda é uma tecnologia de custo inicial elevado, que ainda está em processo de amadurecimento. Trocar todo o parque de iluminação para LED requer um adequado estudo de médio a longo prazo.

Em grande parte dos grandes centros urbanos, o ambiente onde as luminárias de IP são utilizadas é poluído e corrosivo, sendo, portanto, essencial que todas as características ópticas da luminária sejam protegidas contra influências atmosféricas e do meio em que se encontram. A garantia de desempenho ótimo do conjunto de IP, além de uma manutenção adequada, se dá 
através da utilização de compartimentos ópticos e de equipamentos auxiliares protegidos contra poeira e água, com grau de proteção igual ou superior a IP66 ${ }^{4}$ (SCHRÉDER, 2009).

Mesmo aquelas prefeituras que já detêm a muitos anos a responsabilidade pelos ativos de IP, também se nota essa carência na manutenção preventiva, responsável pela qualidade percebida pela população. Para que isso aconteça, é essencial uma estratégia de controle em tempo real, que permita identificar e atuar naqueles equipamentos que necessitam de manutenção antes que parem de funcionar adequadamente. As tecnologias de supervisão em tempo real não é objeto do presente estudo, porém podemos citar algumas já consolidadas que permitem inclusive comando a distância, como IEEE (ZigBee), WiMAX e tecnologias de LAN sem fio (Wi-Fi), celular GSM 3G/4G, DASH 7 e PLC, com foco especial em suas aplicações em Smart Grids ${ }^{5}$. Dessa forma, a gestão do serviço de IP, não depende apenas da reclamação do usuário para proceder a manutenção, que leva a uma demora demasiada no reparo, mas pode atuar inclusive antes do equipamento apresentar defeito.

A discussão sobre a qualidade do fornecimento de serviços à população, sempre será oportuna quando se enfoca a concessão de serviço público, como é o caso da IP. Não se pode perseguir qualidade, quando nem se sabe as condições do seu ativo. Afinal, o esforço que se dispõe para melhorar um serviço está diretamente ligado ao tamanho e à qualidade do que precisa ser melhorado, pois envolve dispêndio financeiro, o que acarretará uma necessidade de mensurar quanto será necessário para que se eleve a qualidade percebida pelo cliente final, conforme o gráfico 3, a seguir.

\footnotetext{
${ }^{4}$ IP66: Trata-se do grau de proteção (IP), apresentado na norma NBR IEC 60529 - "Graus de proteção para invólucros de equipamentos elétricos (códigos IP) ".

${ }^{5}$ Smart Grids: são redes inteligentes de transmissão e distribuição de energia com base na comunicação interativa entre todas as partes da cadeia de conversão de energia. As Smart Grids conectam unidades descentralizadas de geração grandes e pequenas com os consumidores para formar uma estrutura ampla.
} 
Gráfico 3: Benefício marginal e custo de qualidade

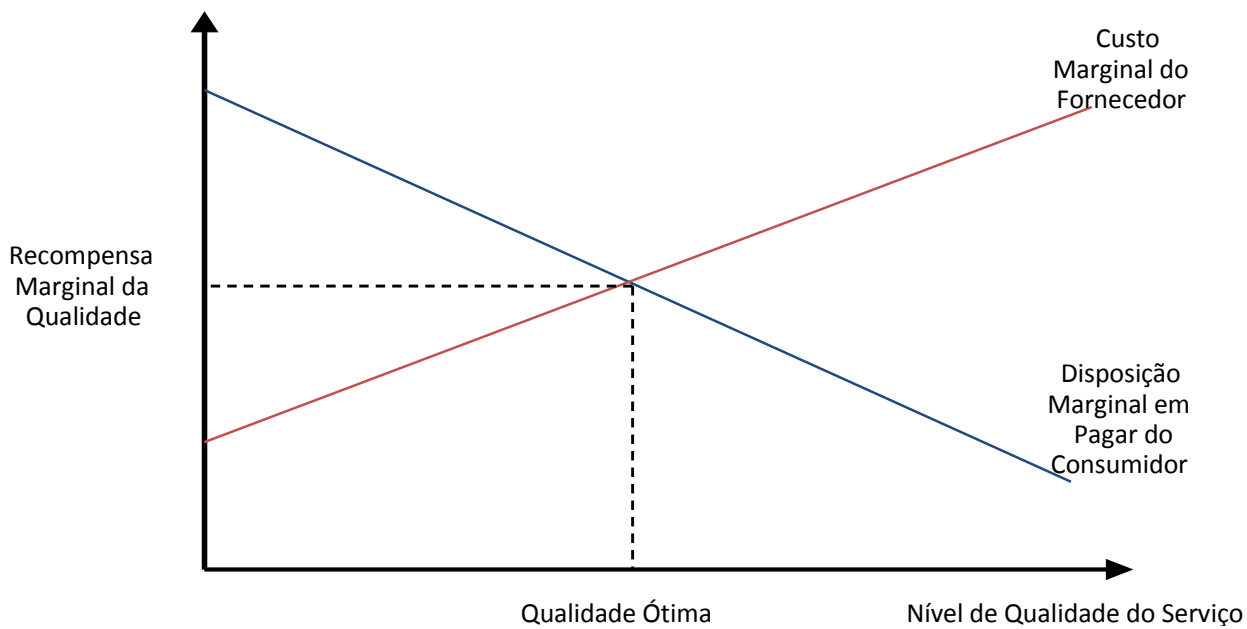

Fonte: Baldiwin (1999)

Conforme Meyrick \& Associates (2002), duas importantes implicações precisam ser consideradas ao interpretar a gráfico acima: nem todos os consumidores valorizam a qualidade do mesmo modo e nem todo fornecedor tem os mesmos custos marginais crescentes com o aumento da qualidade do serviço, ou seja, quanto de esforço financeiro deve-se dispor para promover qualidade percebida que repercute em retorno ao investidor?

No caso das Concessionárias o retorno é indireto, ou seja, pode se beneficiar com os resultados do IASC - Índice ANEEL de Satisfação do Consumidor, que repercutem na revisão tarifária. No caso das prefeituras a situação é mais delicada, pois além de não dispor de reserva financeira disponível suficiente para manter ou melhorar a qualidade dos ativos de IP, necessitando invariavelmente de incentivos do Governo Federal, o retorno não é diretamente ligado ao financeiro, mas ao retorno social de seus munícipes, cuja percepção é ainda mais difícil.

\subsection{Transferência dos Ativos de IP}

O assunto da transferência do ativo de IP para as prefeituras tem sido tema de diversos encontros técnicos, incluindo audiências públicas promovidas por representantes da sociedade e do governo, como por exemplo, Associação dos Engenheiros e a ANEEL, porém, apesar de todo esse esforço, ainda carecem de critérios técnicos e comerciais suficientes para que os prefeitos se sintam confortáveis em receber e passar a gerir esse novo ativo.

Conforme levantamento feito pela ANEEL em maio de 2015, dos 5.564 municípios brasileiros $5.107(91,97 \%)$ assumiram os ativos, ou seja, ainda faltam 457 (8,3\%) do total. Os 
estados mais críticos, demonstrados na tabela 2, são Amapá, Ceará, Minas Gerais, Paraná, Pernambuco, Roraima e São Paulo, porém se observa um esforço no sentido de atender as determinações legais de transferência dos ativos de IP.

Tabela 2: Transferência dos ativos de IP por estado

\begin{tabular}{l|c|c}
\multicolumn{1}{|c|}{ Estado } & Quantidade pendente & Quantidade que assumiu \\
\hline Amapá & 16 & 50 \\
\hline Ceará & 134 & 816 \\
\hline Minas Gerais & 37 & 381 \\
\hline Paraná & 18 & 101 \\
\hline Pernambuco & 84 & 548 \\
\hline São Paulo & 155 & - \\
\hline Roraima & 15 & \\
\hline
\end{tabular}

Fonte: ANEEL (2015)

Segundo apurado nas audiências públicas promovidas pela ANEEL sobre o tema, a maior reclamação dos prefeitos se baseia no fato de terem que arcar com todas as despesas financeiras necessárias para proceder a essa nova atribuição. A distribuidora dispõe de quadro de pessoal técnico qualificado, materiais e equipamentos adequados e uma logística estruturada para suportar essas atividades, que são correlatas. Por esse serviço, o município vinha pagando a tarifa B4b, que inclui o fornecimento de energia e a prestação do serviço de IP - com manutenção dos ativos - pela distribuidora. Após transferência dos ativos de IP aos municípios, será aplicada a tarifa B4a sobre o consumo de energia elétrica do próprio sistema de IP, que é cerca de $9 \%$ menor do que a B4b, resultando num ganho imediato (economia) à municipalidade, na fatura de energia elétrica. Entretanto, a prefeitura passará a ter despesas com operação e manutenção do sistema de IP, que antes não possuía. (GUIA DO GESTOR SP, 2013)

Nesse sentido, o município tem possibilidade de arrecadar recursos através da Contribuição de Iluminação Pública (CIP), cuja receita poderá ir para um Fundo Municipal de Iluminação Pública (Fmip), com a finalidade de custear a prestação dos respectivos serviços. Para tanto, a municipalidade terá que aprovar e sancionar uma Lei Complementar (LC), seguida de decreto que a regulamente. A LC somente poderá entrar em vigor no exercício seguinte à sua instituição. 
O mesmo procedimento vale para os casos de alteração do valor da CIP, ou seja, para aumentar o valor de uma CIP já existente destinado a cobrir as despesas adicionais com operação e manutenção do sistema de IP.

Os municípios que já têm a CIP deverão avaliar se a arrecadação é suficiente para fazer frente a todas as despesas com IP. Se o município dimensionou a CIP somente para o custeio do consumo de energia, ao assumir a manutenção e operação desse sistema precisará aumentar a arrecadação. Para os municípios que não criaram ou que não vão criar a CIP por uma decisão local, dependerá de outros meios para obter recursos para essa nova demanda, como por exemplo, através de um incremento no Imposto Predial e Territorial Urbano (IPTU) do município. O processo será mais simples para os municípios de médio e grande porte, pois apresentam maior número de pontos de IP, tornando-se mais atrativos aos prestadores desses serviços nos processos licitatórios, caso optem pela contratação de terceiros. Há ainda a possibilidade de estabelecerem estrutura própria para operar e manter os ativos de IP. Para os pequenos municípios, a melhor alternativa pode ser a formação de consórcios que ampliem a atratividade do mercado na prestação dos serviços de IP.

\subsection{Diversidade dos Ativos de IP}

De acordo com Silva (2006), a IP não é um serviço público regulado de forma centralizada e a prestação deste serviço é de competência dos mais de 5.560 municípios brasileiros. Por esta razão, existe grande diversidade de sistemas, tecnologias, níveis de atendimento e de qualidade dos serviços prestados.

As desigualdades percebidas no Brasil, principalmente quanto às condições financeiras das prefeituras, também se refletem na IP em diversos níveis como:

$\checkmark$ Regional-existem regiões do país onde o número total de pontos por habitante é consideravelmente mais expressivo do que em outras, o que distingue a diferença do índice de habitantes por $\mathrm{km}^{2}$ de vias iluminadas;

$\checkmark$ Local - dentro de um mesmo município podem ser verificadas localidades urbanas onde ainda não existe IP, o que pode inclusive sinalizar a falta de outros pontos na infraestrutura básica, não só de IP, mas também de água, saneamento, pavimentação etc. 
$\checkmark$ De tecnologia - regionalmente ou localmente são encontradas discrepâncias entre as tecnologias aplicadas. As luminárias mais modernas são utilizadas nos grandes centros urbanos, em grandes avenidas e ruas importantes da cidade e em municípios menos favorecidos ainda são instalados sistemas com luminárias pouco modernas;

$\checkmark$ De obsolescência e depreciação física - a vida útil dos equipamentos constituintes dos sistemas de iluminação, quando ultrapassada, pode aumentar as perdas do sistema, reduzir o rendimento dos equipamentos e não atingir os níveis mínimos de qualidade de serviço que possam conferir a segurança desejada de acordo com os parâmetros de projeto. Tecnologias obsoletas podem também fornecer serviços com qualidade inferior, além de, em geral, representarem um maior consumo de energia;

\section{MÉTODO}

A opção pelo método descritivo e explicativo, teve por objetivo revelar o passo a passo, o caminho percorrido pelo pesquisador, para que o leitor possa utilizá-lo para reproduzi-lo em trabalhos futuros.

Do ponto de vista dos objetivos da pesquisa, Gili (1991) afirma que a pesquisa descritiva visa descrever as características de determinada população ou fenômeno ou o estabelecimento de relação entre variáveis. Envolve o uso de técnicas padronizadas de coleta de dados: questionários e observação sistemática. Assume em geral, a forma de levantamento. Já a pesquisa explicativa, visa identificar os fatores que determinam ou contribuem para a ocorrência dos fenômenos. Aprofunda o conhecimento da realidade porque explica a razão, identificando o "por que das coisas".

Quanto mais exata for à coleta de informações, mais segurança ter-se-á na identificação dos requisitos necessários para compor o cadastro técnico e em consequência estabelecer a arquitetura de internalização dos dados, que venha a preencher as lacunas e as necessidades de informações da operação, da manutenção preventiva, da expansão e da adequação da rede de IP com o desenvolvimento tecnológico. 


\section{RESULTADOS}

Os resultados apurados através desta metodologia além da coleta de informações, requer uma estrutura informatizada para internalização dos dados coletados, de forma segura e confiável, estabelecendo uma arquitetura que possa preencher as lacunas e as necessidades de informações da operação, da manutenção preventiva, da expansão e da adequação da rede de IP com o desenvolvimento tecnológico.

A base primária que recebe as informações coletadas em campo é o mapa georeferenciado do município em estudo. Quando esse documento não existir, é sugerido ao gestor público a contratação de empresa especializada que possa elaborar esse importante documento, que será útil não só para a internalização dos dados de IP, como de outros ativos da cidade.

A metodologia está dividida nas seguintes etapas:

\subsection{Estudo luminotécnico}

Conforme definido nos objetivos específicos desse trabalho, a insuficiência de fluxo luminoso no sistema de IP, os chamados de "pontos escuros", precisa ser identificada, porém, antes dessa etapa, cabe uma explicação do que é um "ponto escuro".

O ponto escuro é caracterizado pela falta de continuidade do nível de iluminância entre dois pontos luminosos, provocados por fatores que vão desde interferências de origem externa ao sistema de IP, como a presença de arborização sob a fonte luminosa, até a baixa eficiência energética das luminárias ou espaçamentos entre postes maiores que os admissíveis pela resposta luminosa das luminárias, acarretando uma sensação visual incômoda, como demonstrado na figura 11. 
Figura 11: Distribuição de intensidade luminosa - Identificação do ponto escuro

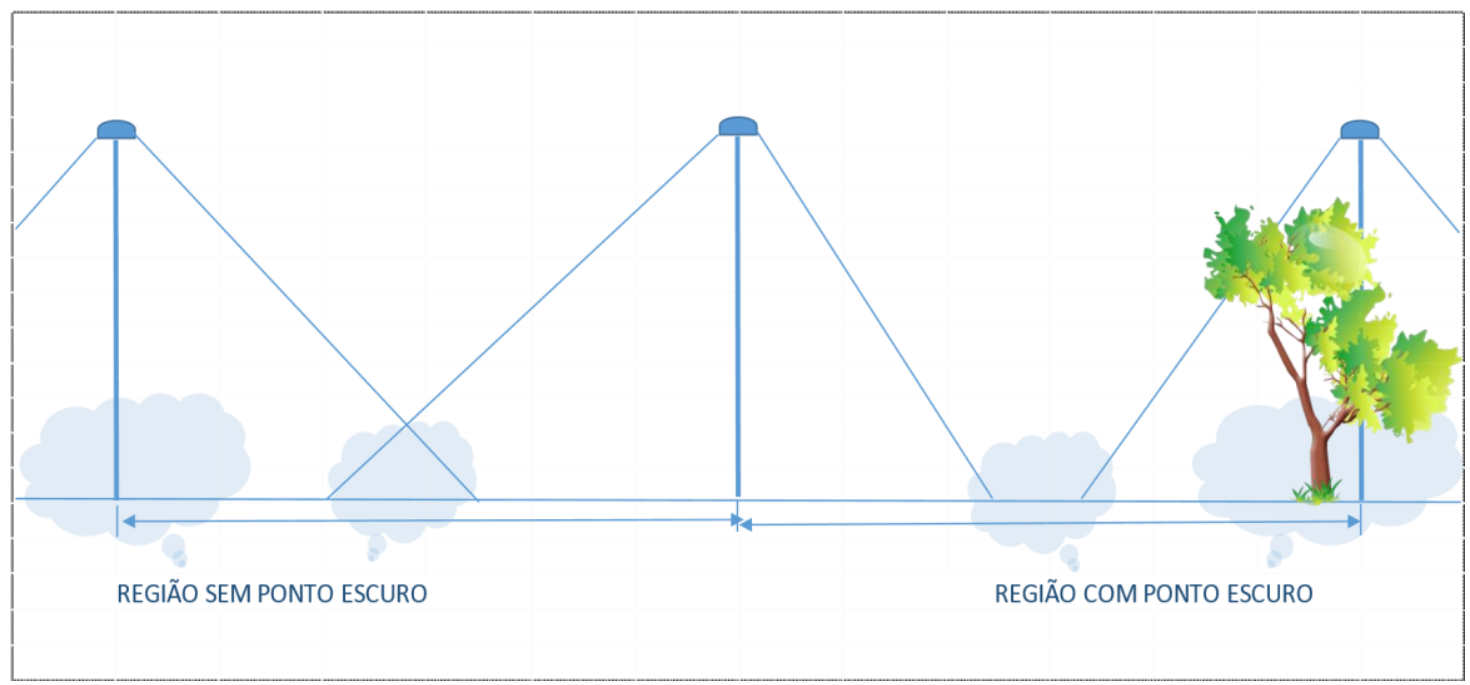

Fonte: Autor, 2014.

A norma NBR 5101 (2012), prevê que para as inspeções de iluminância sejam definidos pontos de medições que criem uma grade elaborada a partir de interseções das linhas longitudinais e transversais entre a pista de rolamento e a calçada, criando uma malha de medição, conforme a figura 12 e 13 .

Figura 12: Malha de medições luminotécnicas

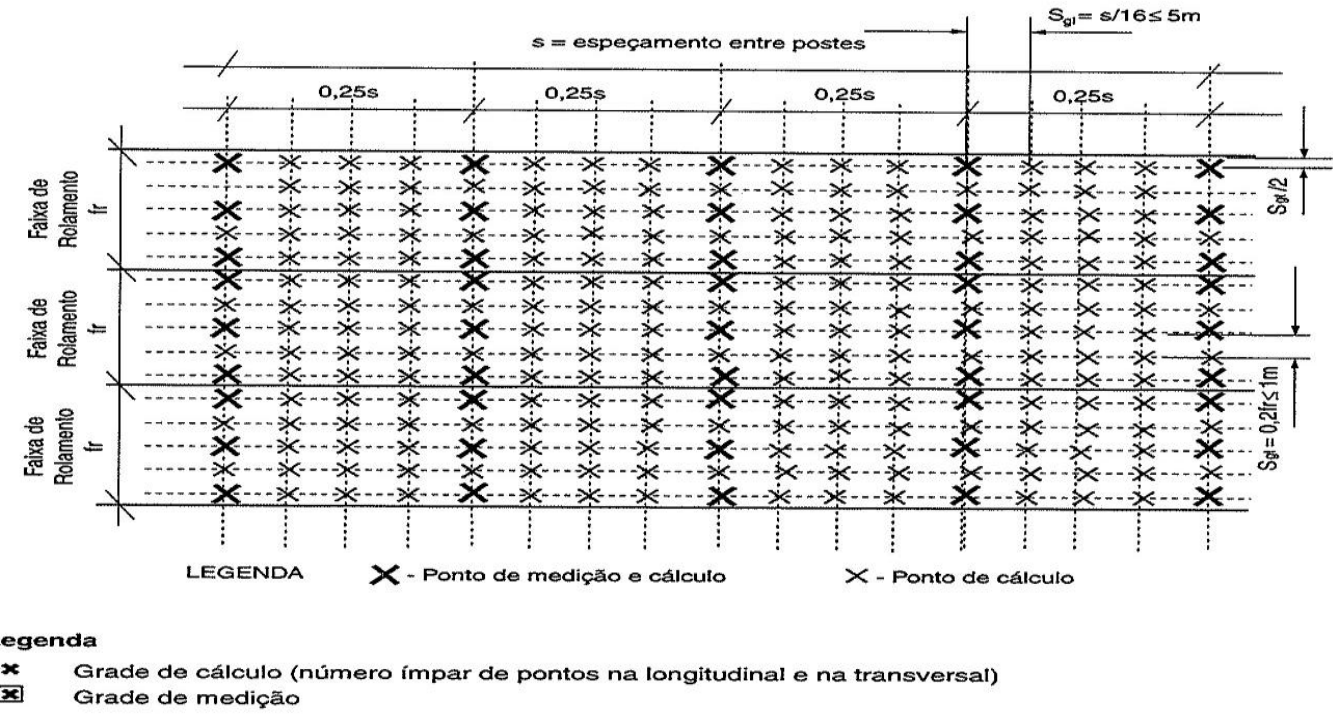

Fonte: NBR 5101, 2012. 
Figura 13: Metodologia de medição pela NBR 5101/2012 para uma faixa de rolamento.

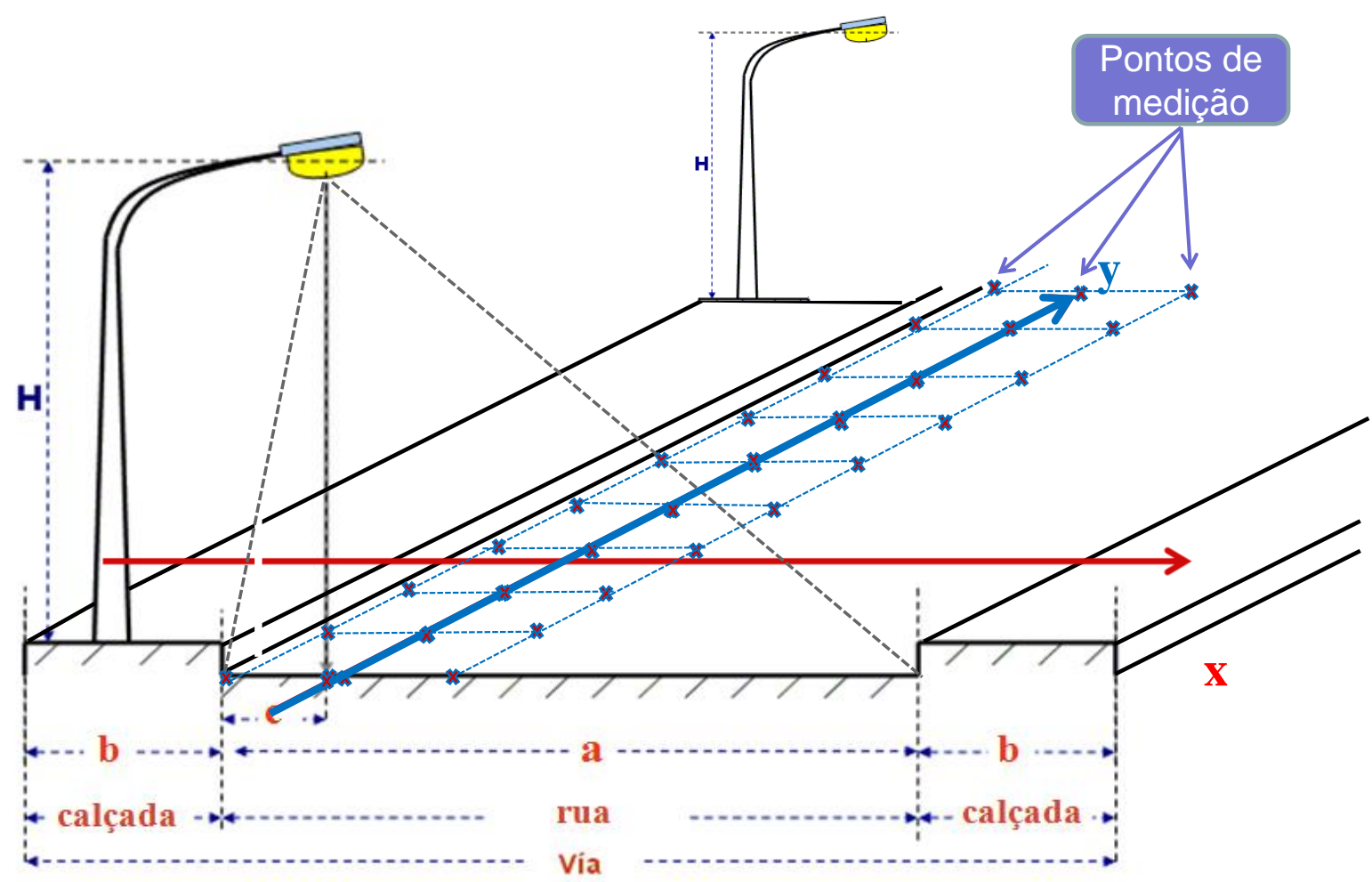

Fonte: Autor, 2015.

Como no estudo em questão o objetivo é identificar os pontos escuros existentes em toda a extensão territorial da cidade, que compreende aproximadamente $300 \mathrm{~km}$ lineares de rede de IP, utilizar a metodologia recomendada acima, mostrou-se impraticável, tendo em vista os problemas encontrados em campo, que vão desde carros estacionados na guia até a necessidade de interdição da rua ou avenida em função das medições no leito carroçável, impraticável em algumas avenidas de grande movimentação de veículos, mesmo durante o período noturno. Em razão disso, se optou pela adoção de uma metodologia mais prática, que, apesar de não ser tão eficiente quanto à adotada pela NBR 5101 (2012), permitisse efetuar as medições de forma rápida e eficaz, sem comprometer a segurança da equipe de medição.

Nesta metodologia, foram realizadas medições de iluminância a cada 1 metro, apenas embaixo de cada luminária ao longo dos vãos entre luminárias, utilizando fotômetros e unidades GPS sincronizados, ou seja, no momento da medição de iluminância, ocorre a localização georeferenciada dessa medição. Através deste critério foram desprezadas as medições junto à guia e na extremidade da faixa de rolamento, ficando apenas as medições do centro da grade de medições, como demonstrado na figura 14. As demais medições foram interpoladas através do método geoestatístico de krigagem, que utiliza funções matemáticas para acrescentar pesos 
maiores nas posições mais próximas aos pontos amostrais e pesos menores nas posições mais distantes, e criar assim os novos pontos interpolados com base nessas combinações lineares de dados.

Figura 14: Metodologia de medição adotada no estudo

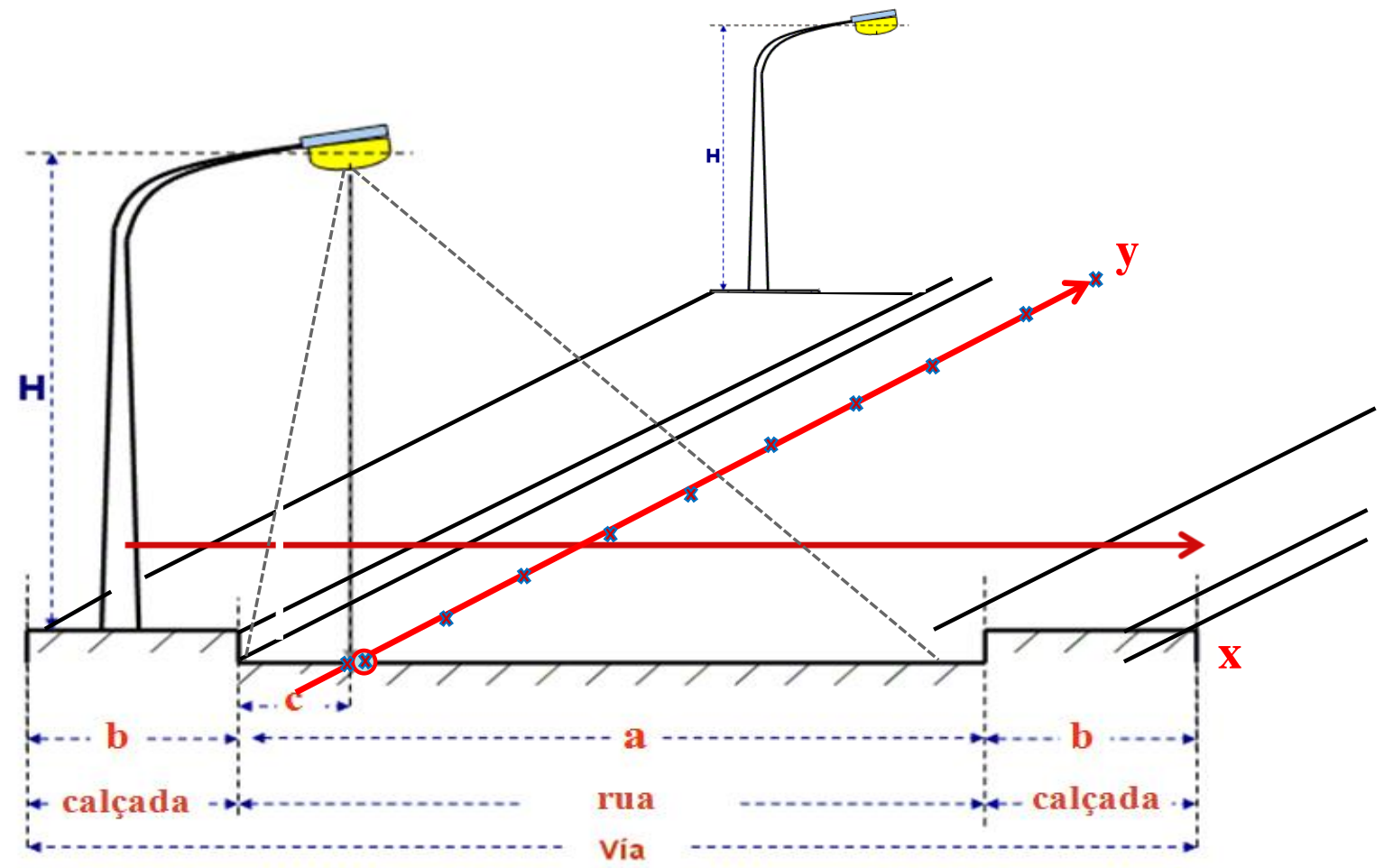

Fonte: Autor, 2015.

Como a coleta de dados se deu em ambiente urbano, identificaram-se novos problemas que necessitaram de soluções para a realização das medições. O primeiro, diz respeito às possíveis interferências típicas de um ambiente urbano, como faróis de carros, fachadas iluminadas, excesso de arborização, que poderiam comprometer as medições luminotécnicas.

A fim de buscar as soluções para os problemas apontados acima, foi adotado um estudo piloto em uma rua considerada típica da maior parte das ruas da cidade do estudo, para avaliações preliminares tendo como referência a norma ABNT 5101: 2012. O experimento se deu da seguinte forma:

- Medição no nível de solo, sob as luminárias, conforme determina a NBR-5101;

- Medições a 1,5 m de altura, sob as luminárias, simulando o posicionamento do fotômetro sobre um veículo; 
O resultado das medições feitas nas duas situações apresentadas acima, foram inseridas ao $\mathrm{ArcGIS}^{6}$, e aplicado um método de interpolação denominado SwB (Spline with Barriers) ${ }^{7}$.

Como pode ser observado na figura 15 , as médias de intensidade de luz que geraram as duas imagens são bem semelhantes visualmente, com um pequeno acréscimo de intensidade luminosa, obviamente esperado, na medição a 1,5 $\mathrm{m}$ do solo, que seria o modelo adotado para as medições em toda a amostra.

\section{Figura 15: Interpolação de dados - sistema SwB}

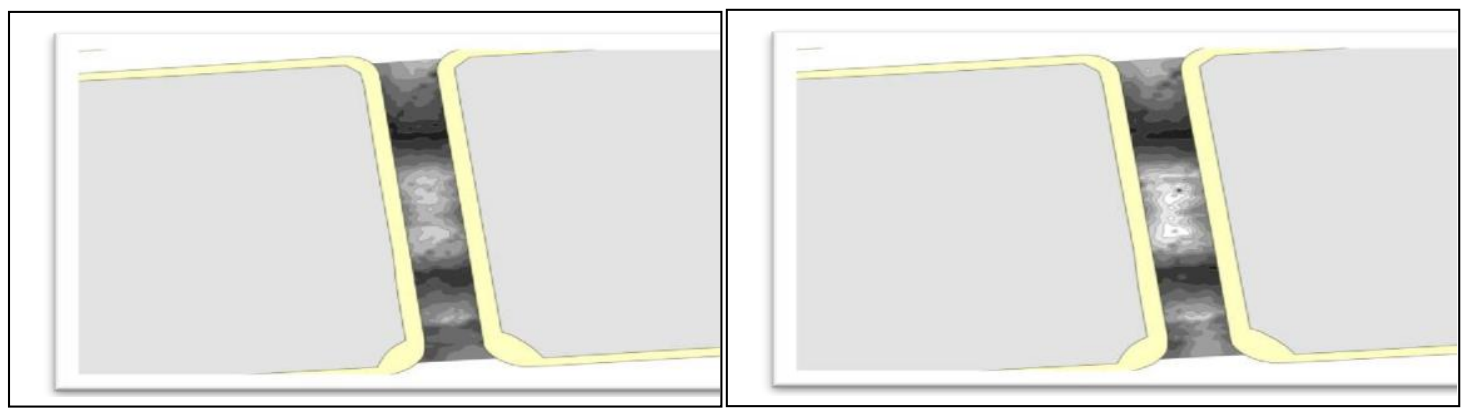

Medição luminotécnica no nível do solo

Medição luminotécnica a $1,5 \mathrm{~m}$ do solo

Fonte: Medral Geotecnologia, 2012.

Após a criação das curvas de nível de iluminação, foi realizado o cálculo de Fator de Uniformidade $(\mathrm{U})$ e Iluminância Média $\left(\mathrm{E}_{\mathrm{med}}\right)$, utilizando as seguintes formulas:

- Iluminância Média $\left(\mathrm{E}_{\mathrm{med}}\right)$

Emed $=\frac{\sum(\text { area } \times \text { LuxMedio })}{\sum(\text { area })}$
- $\quad$ Fator de Uniformidade (U)

$$
U=\frac{\text { Emed }}{\min (\text { LuxMedio })}
$$

Em seguida, foi montado o equipamento de medição em cima de um veículo pequeno (tipo Uno - obedecendo à altura de $1,5 \mathrm{~m}$ ) e feito nova medição em uma área mais abrangente, porém apenas na linha longitudinal abaixo da luminária, como mostra figura 16.

\footnotetext{
${ }^{6}$ ArquiGIS: é uma plataforma colaborativa, baseada no sistema de nuvem que permite aos membros de uma organização utilizar, criar e compartilhar mapas, aplicativos e dados e acessar mapas base autorizados e aplicativos ArcGIS. É produzido pela ESRI

${ }^{7}$ Spline with computacional Barriers: método de interpolação de dados aderente ao sistema ArcGIS`
} 
Figura 16: Levantamento fotométrico com veículo

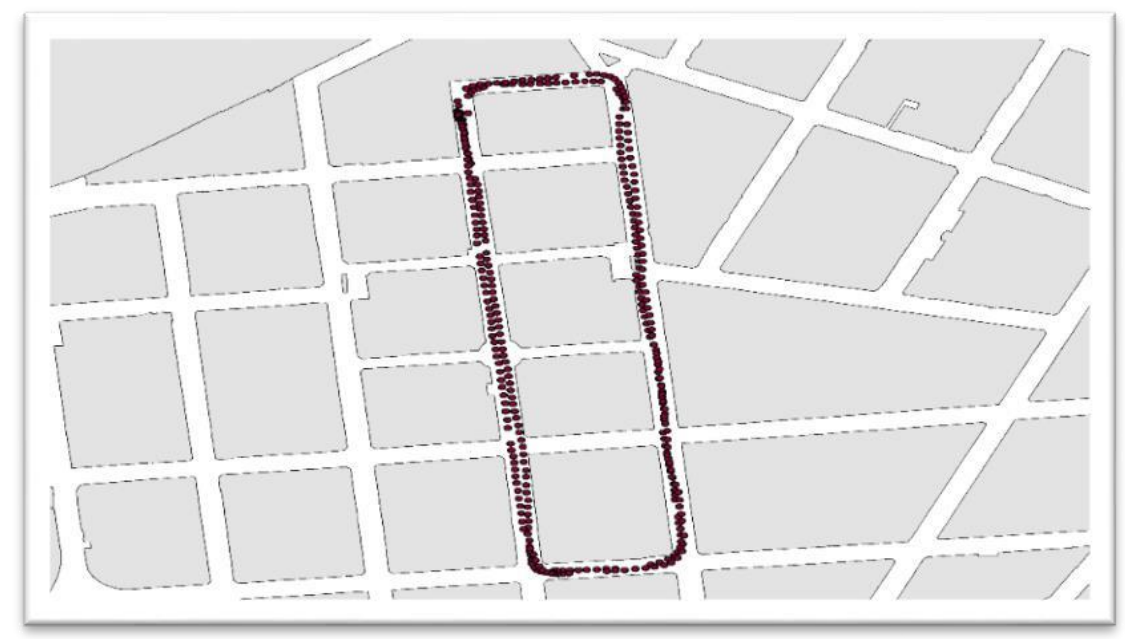

Fonte: Medral Geotecnologia, 2012.

Seguindo o mesmo procedimento, aplicou-se o método de interpolação SwB em todo o conteúdo de dados medidos por todo campo de prova que, posteriormente, também foram inseridos no ArcGIS, gerando imagens de intensidades luminosa apresentadas na figura 17.

Figura 17: Interpolação de dados com veículo

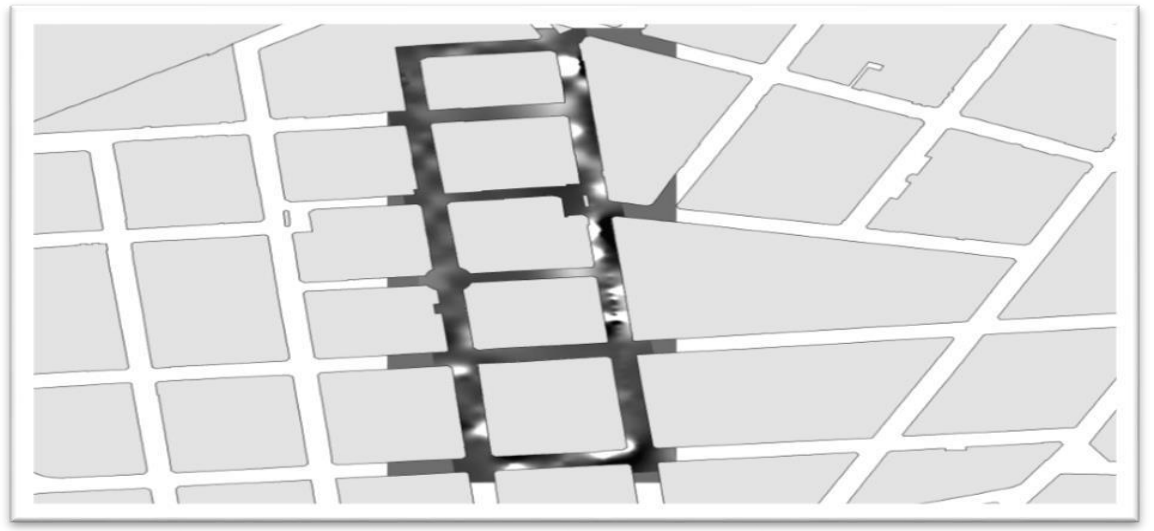

Fonte: Medral Geotecnologia, 2012.

Após o método de interpolação, a área estudada foi isolada para comparação dos resultados anteriores (Figura 18). 
Figura 18: Interpolação de dados na área isolada

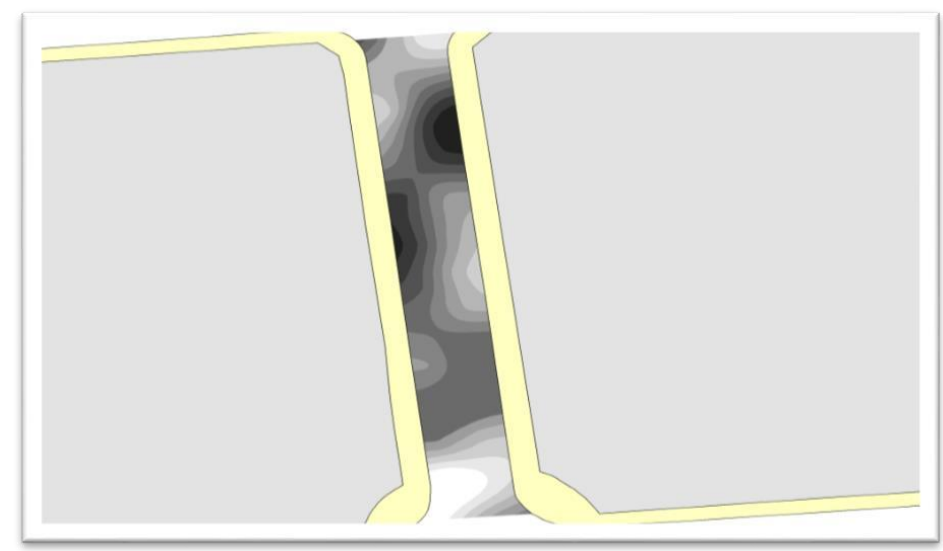

Fonte: Medral Geotecnologia, 2012.

Como necessitávamos que as medições fotométricas ocorressem sobre um veículo, a uma altura de 1,5 metros, procederam-se testes que identificassem as perdas dessa elevação do solo, cujo resultado visual está demonstrado na figura 19.

Figura 19: Comparação entre os procedimentos de medição

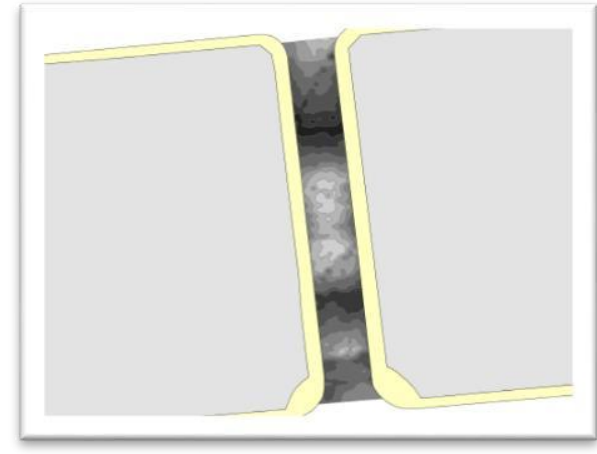

Medição ao nível do solo

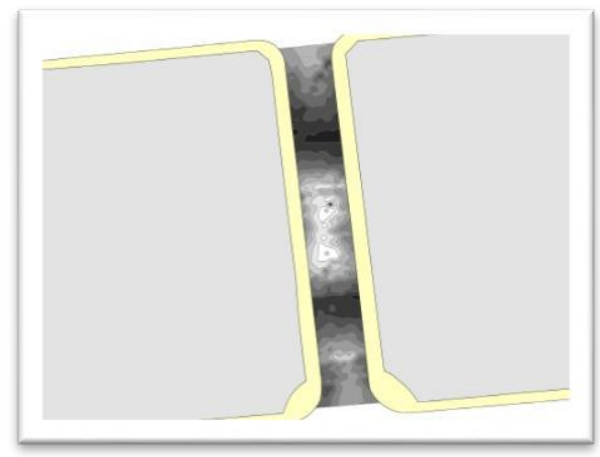

Medição a $1,5 \mathrm{~m}$

Fonte: Medral Geotecnologia, 2012

Ao analisar visualmente as curvas acima se nota que a curva de nível gerada pelos processos ao nível do solo e a 1,5m de altura foi praticamente à mesma, porém quando se aplica as formulas aos resultados obtidos, notou-se uma diferença de $11 \%$ entre as médias de iluminância $\left(\mathrm{E}_{\mathrm{med}}\right)$, demonstrado na tabela 3 , que poderia ser descontado das medições futuras a fim de se obter o mesmo resultado a nível do solo. 
Tabela 3: Medições fotométricas em diferentes alturas

\begin{tabular}{|ccc|}
\hline & Nível do solo & Altura de 1,5 m \\
\hline Emed & 1,83 Lux & 2,04 Lux \\
& Referência & $<11 \%$ \\
\hline
\end{tabular}

Fonte: Autor, 2015

Com esse resultado e considerando o objetivo específico de identificar "pontos escuros", a metodologia utilizada mostrou-se adequada, pois possibilitaria distinguir as diferentes intensidades luminosas utilizando o mesmo procedimento em todas as medições efetuadas no estudo, considerando a mesma escala de referência.

Com a aplicação desta metodologia em todo o parque de IP se obteve um mapa temático específico de pontos escuros, conforme figura 20, obtida em situação real.

Figura 20: Mapa temático de pontos escuros

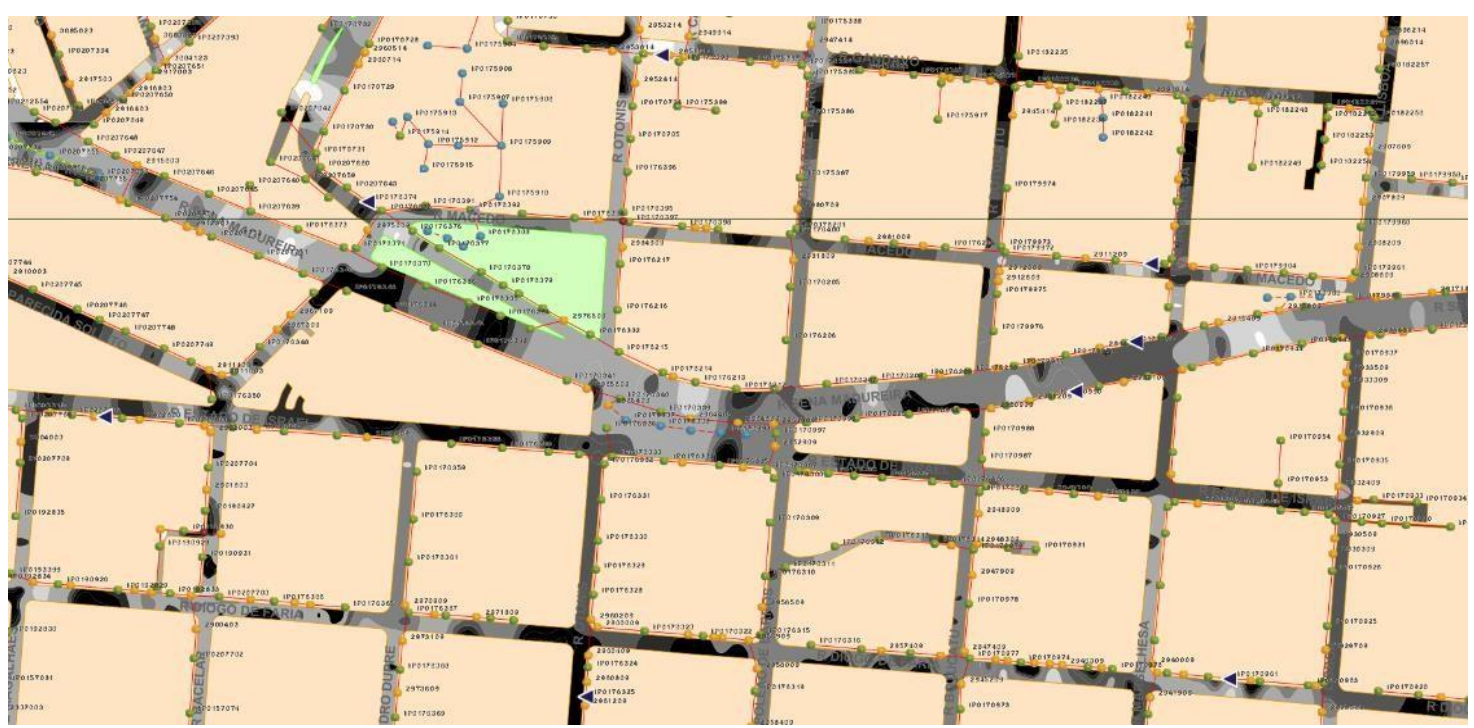

Fonte: Medral Geotecnologia, 2012.

O procedimento de coleta de dados com um luxímetro integrado a um GPS obtém-se uma coordenada por segundo, o que implica que a velocidade do veículo deve ser inferior a $40 \mathrm{~km} / \mathrm{h}$ para que os espaços entre as medições não sejam superiores a $10 \mathrm{~m}$. As medições foram efetuadas entre $20 \mathrm{~h} 00$ e $24 \mathrm{~h} 00$, quando o trânsito de veículos costuma ser reduzido, a fim de minimizar possíveis interferências provocadas por faróis de outros veículos. 
Para que fosse possível valorar os diversos níveis de intensidade luminosa encontradas, tomando por base a Norma NBR 5101 (2012), foi criada uma escala de classificação das curvas de intensidade luminosa, descrita abaixo, a partir das medições efetuadas em campo, que possibilitou classificar os pontos escuros da seguinte forma:

- Classe I (0 a 2 Lux) e Classe II (2 a 5 Lux) - Iluminação insuficiente.

- Classe III (5 a 10 Lux) e IV (10 a 20 Lux) - Iluminação onde a eficiência depende da classificação da via, conforme NBR 5101 (2012).

- Classe V (20 a 50 Lux), VI (50 a 100 Lux) e VII (mais de 100 Lux) - Iluminação suficiente para qualquer tipo de via, que extrapola os limites definidos pela NBR $5101(2012)$.

\subsubsection{Equipamentos utilizados}

Para medir a iluminância foi utilizado um fotômetro industrial do tipo HD450 (Figura 21).

Figura 21: Luxímetro utilizado nas medições fotométricas

- Armazena automaticamente até 16.000 leituras ou armazena/rechama manualmente até 99 leituras

- Visor grande de LCD com luz de fundo com gráfico de barras de 40 segmentos

- Amplo alcance de $40.000 \mathrm{Fc}$ ou 400.000 Lux.

- Medições do cosseno e coloridas corrigidas

- Utiliza fotodiodo de silicone de precisão e filtro de resposta espectral. O modo de pico $(10 \mu \mathrm{S})$ capta a leitura mais alta

- O modo relativo indica uma mudança nos níveis de iluminação Mín/Máx e armazenamento de dados

- Luz de fundo para leituras em níveis de iluminação baixos

- Porta USB integrada para descarregar

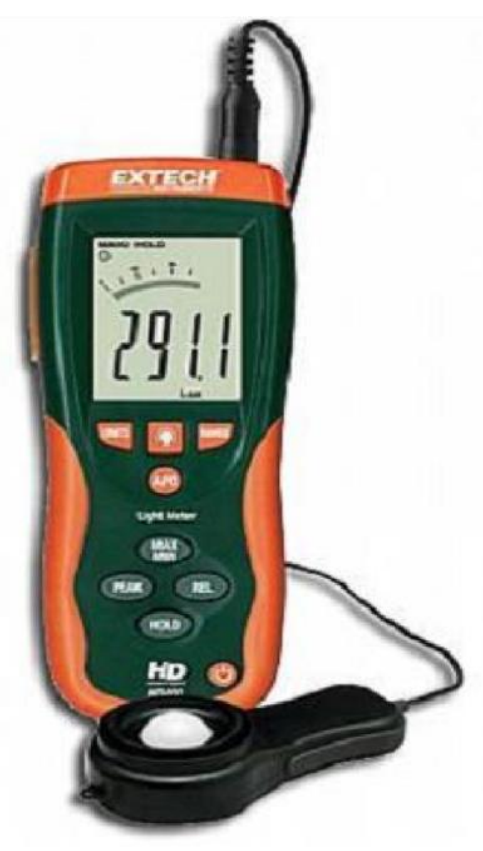


O fotômetro possui memória interna de 16 mil leituras, e foi configurado para capturar uma leitura a cada 2 segundos, resultando em um tempo útil de +/- 9 horas de leituras.

Posteriormente, os dados serão descarregados para um PC utilizando-se a interface USB, conforme a figura 22 .

Figura 22 Imagem dos dados coletados

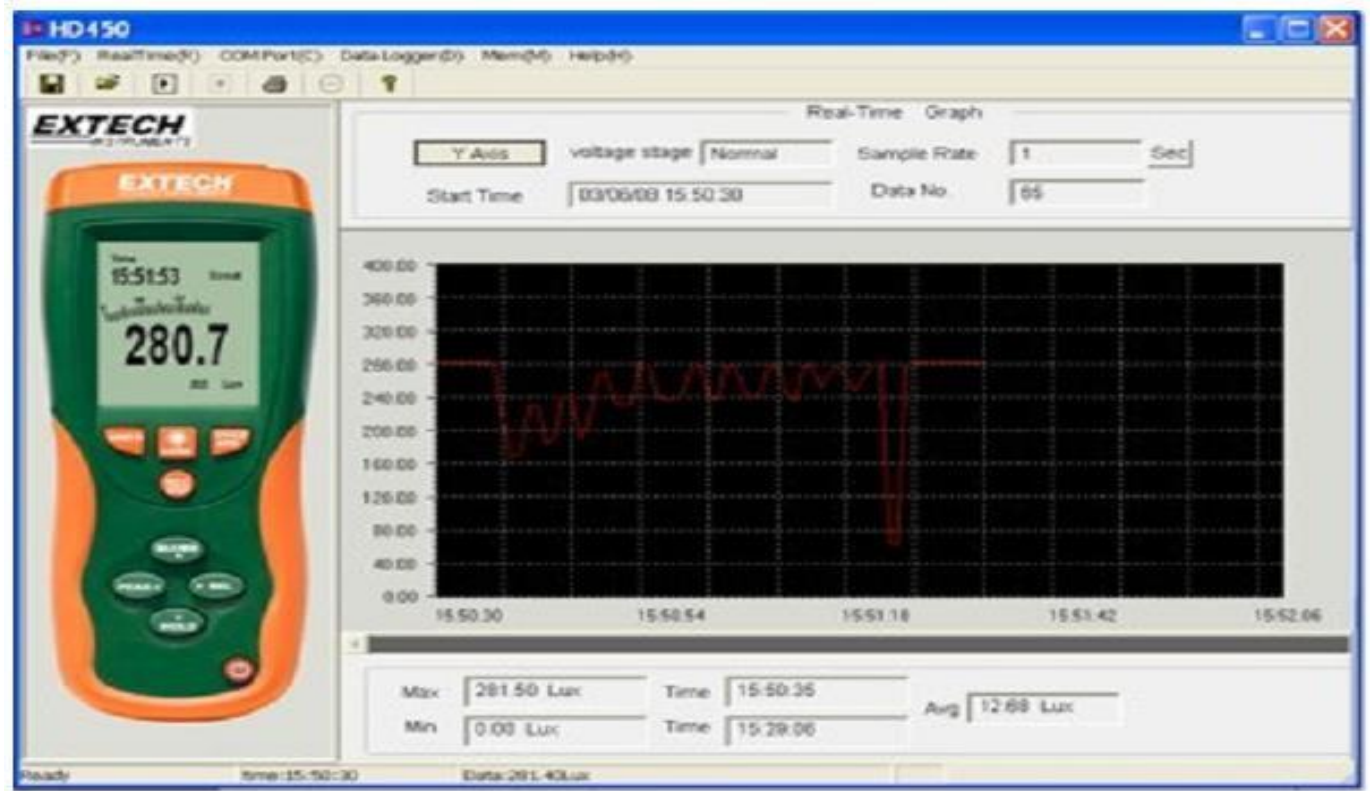

Fonte: EXTECH, 2011.

Para a coleta de coordenadas em modo sistemático, foi utilizado um coletor GPS com antena externa, com relógio sincronizado com o fotômetro, demonstrado na figura 23.

Figura 23: Equipamento GPS utilizado

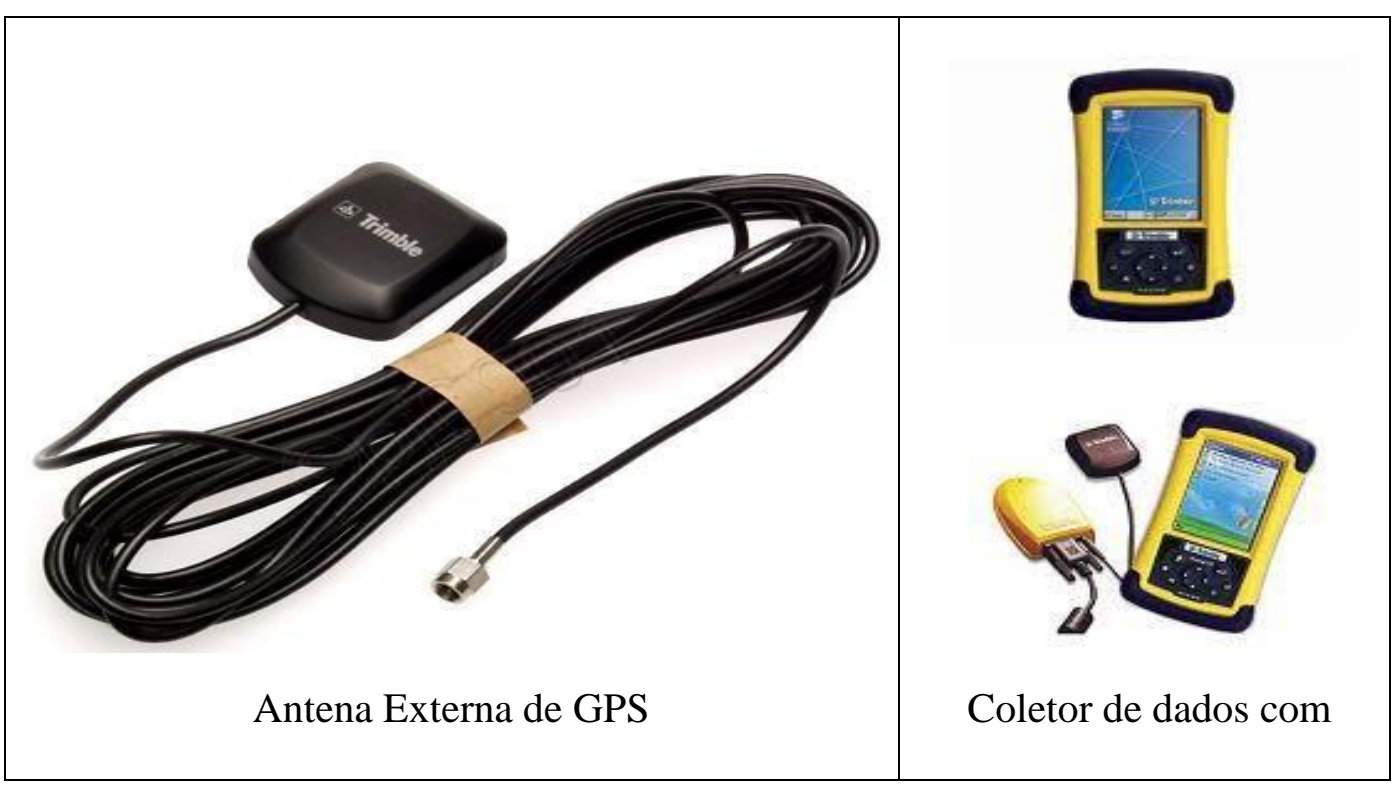

Fonte: TRIMBLE, 2011. 


\subsection{Etapa de planejamento}

Um adequado planejamento é prescindível para início das etapas de levantamento, a fim de prevenir retrabalhos e distorções dos dados coletados, portanto é adequado que seja feito um estudo sobre a cidade, que será objeto do cadastramento de IP, tanto no período diurno quanto noturno, a fim de recolher informações que permitam definir o perfil da cidade (residencial, agrícola, industrial, etc.), conhecer a extensão dos meios viários, seu fluxo de trânsito, suas áreas de risco (especialmente relacionados à segurança) e outras informações que contribua para a formação e orientação da equipe de cadastradores.

São necessárias reuniões com representantes da prefeitura e/ou da Concessionária de Distribuição de Energia, buscando a definição dos seguintes tópicos:

a) Definição da propriedade dos softwares (licenças, código fonte, etc.)

É necessário definir se será utilizado um software existente no mercado ou será criado um específico para aquele cadastramento. Também é conveniente que se defina a futura manutenção do sistema.

b) Definição do tipo de sistema computacional de gerenciamento do banco de dados que suportará a internalização dos dados (SQL Sever ${ }^{8}$ da Microsoft, Oracle, IBM Infomix, etc).

Um sistema de gerenciamento de banco de dados é um conjunto de programas que permitem armazenar, modificar e extrair informações de um banco de dados.

É recomendado que a solução informatizada adotada seja capaz de suportar plataformas, tipos de arquivos e aplicativos comerciais amplamente utilizados no mercado para serviços de natureza similar, considerando as seguintes características:

○ Interface gráfica com o usuário na língua portuguesa;

- Possuir mecanismos de controle e restrições de acesso;

○ Garantir a padronização e validação dos dados;

\footnotetext{
${ }^{8}$ SQL Server: Sistema gerenciador de banco de dados, desenvolvido pela Microsolt. Sua principal função é a de armazenar e recuperar dados solicitados por outras aplicações de software, seja aqueles no mesmo computador ou aqueles em execução em outro computador através de uma rede (incluindo a Internet).
} 
- Amplo conjunto de opções de consultas e relatórios dinâmicos, incluindo a emissão de mapas em diversas escalas, padronizados em quadriculas, desde o início do cadastramento, garantindo o total monitoramento do parque instalado e das atividades em evolução;

- As ferramentas de GIS (Geographic Information System) precisam possuir certificação OGC (Open Geospatial Consortium), que garantem a integração dos sistemas;

- Toda a solução deve direta e integralmente ser compatível com a Base Cartográfica oficial da Prefeitura, objeto do estudo;

- Permitir o uso dos diversos sistemas de coordenadas adotados no Brasil, contendo ferramentas de conversão entre estes;

- Permitir a inclusão de um número indeterminado de novas camadas (layers), temas e imagens e permitem a elaboração de análises e estudos dos dados do cadastro, através de pesquisas gráficas e/ou alfanuméricas;

- Permitir a importação e exportação direta de dados de, e para, aplicativos comerciais de CAD (Computer Aided Design), GIS (Geographic Information System), bancos de dados e para a produção de documentos (Microsof Office);

- Permitir a conexão com a equipe de campo através de equipamento móvel, suportar plataformas de aplicações Web com interfaces padrões do mercado e possuir um conjunto de aplicativos Web voltados à consulta, com ferramentas de visualização, "zoom", busca, seleção e impressão de mapas temáticos e de dados;

- Dispor de recursos de desenvolvimento de aplicações, orientado a objetos, compatíveis com as plataformas "Net" e "Java".

c) Definição dos hardwares que suportarão o sistema computacional, desde desktops, servidores, notebooks, impressoras, PDA - Personal Digital Assistants, etc.

- Os equipamentos devem ser compatíveis com as necessidades de escritório, especialmente capacidade de memória adicional, e de campo, especialmente robusto o suficiente para suportar intempéries e danos provocados por quedas, umidade, etc.

d) Definição dos documentos e dados que serão coletados nas fontes de pesquisa: Prefeitura, Concessionária e no campo. 
○ É necessário procedimento para garantir que os documentos não sejam extraviados total ou parcialmente, nem sofram alterações de conteúdo.

○ É necessário procedimento de catalogação dos documentos encontrados.

e) Definição dos rumos do acervo de IP do município em estudo (visão de futuro da cidade).

- Conhecimento do Plano Diretor da cidade, suas metas e seu cronograma de execução.

f) Definição e designação de colaborador ou colaboradores, dentro da Prefeitura e/ou da Concessionária que ajude e participe da coleta de informações.

○ Formação de equipe que acompanhará todo processo e será treinada para opera-lo, assim como replicará o conhecimento com os demais colaboradores envolvidos na gestão da IP.

\subsection{Etapa de levantamentos}

Na figura 24, está descrito o diagrama esquemático do levantamento de dados. O primeiro módulo é destinado à busca e recolhimento de informações em arquivos nos escritórios da Concessionária local e da Prefeitura. O segundo módulo se destina a busca e recolhimento de informações nas ruas e avenidas do município objeto do estudo.

Figura 24: Diagrama esquemático do levantamento de dados
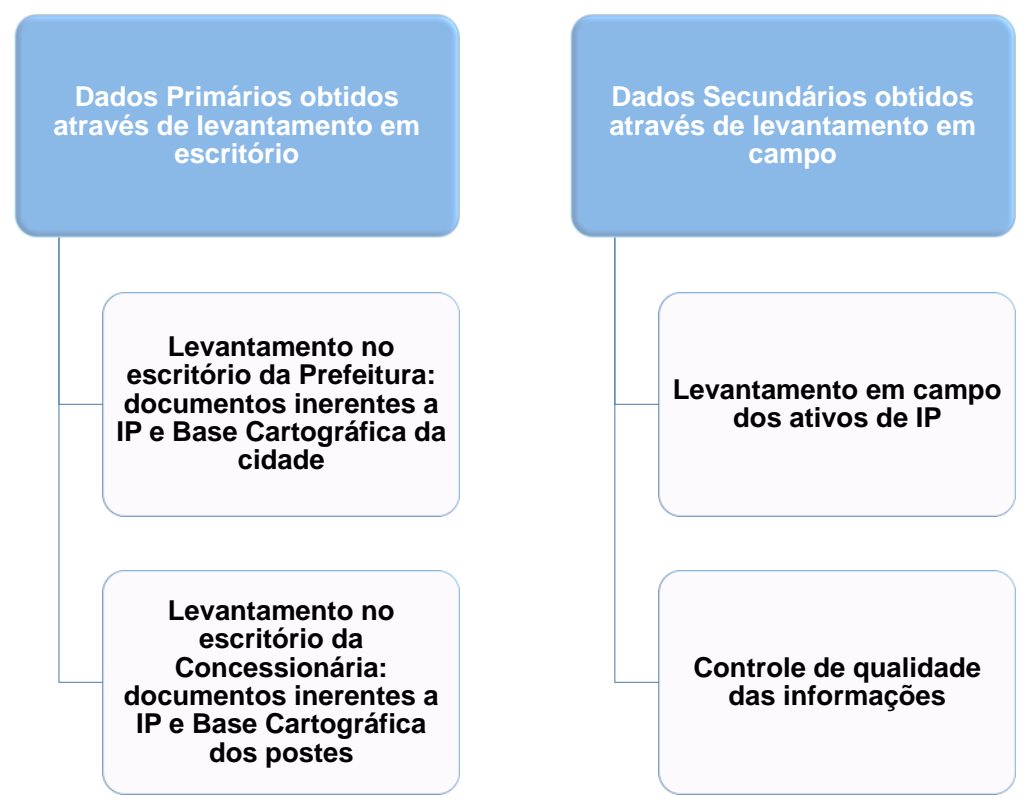

Fonte: Autor (2014) 


\subsubsection{Levantamento em escritórios}

No escritório da Concessionária local:

a) Cadastro atualizado do acervo de IP, de preferência georreferenciado, contendo principalmente a localização dos postes, as estruturas de IP incluindo os transformadores, condutores, braços, luminárias, lâmpadas e comandos;

b) Projeto Reluz ${ }^{9}$ realizados na cidade nos últimos 10 anos, contendo os locais onde foram realizados os trabalhos, com a descrição de qual critério de eficiência energética foi considerado (Tipo e Potência da Lâmpada (X) que substituiu o Tipo e Potência da Lâmpada $\mathrm{Y})$;

c) Relatório de ocorrências envolvendo IP, por localidade, tipo de ocorrência e serviço realizado no último ano;

d) Planejamento de IP previsto para a cidade para o próximo ano;

e) Dados estatísticos das ocorrências de IP sofridas nos últimos 12 meses, caso o tele atendimento esteja aos cuidados da Concessionária.

No escritório da Prefeitura:

a) Base Cartográfica Georreferenciada do município, contendo principalmente os limites do distrito, quadras prediais e viárias e logradouro (eixo, nome da rua, numeração, medidas viárias);

b) Informação sobre os Projetos Reluz realizados na cidade nos últimos 10 anos, contendo locais onde foram realizados os trabalhos, com a descrição de qual critério de eficiência energética foi considerado (Tipo e Potência da Lâmpada (X) que substituiu o Tipo e Potência da Lâmpada Y);

c) Planejamento de IP previsto para a cidade para o próximo ano (se houver);

d) Planejamento de IP previsto para a cidade para os próximos 5 anos (se houver);

e) Plano Diretor de IP (se houver);

f) Dados estatísticos das ocorrências de IP sofridas nos últimos 12 meses, caso o Tele atendimento esteja aos cuidados da Prefeitura.

O objetivo dessa coleta de informações é obter todo o histórico da vida pregressa do ativo, ou seja, saber por quais ações de melhorias esse ativo passou e como se comportou até o momento. Também é importante para buscar o cadastro do acervo vigente (caso exista), onde é

\footnotetext{
${ }^{9}$ Reluz: O Programa Nacional de Conservação de Energia Elétrica (Procel) promove o uso eficiente da energia elétrica, combatendo o desperdício e reduzindo os custos e os investimentos setoriais. Criado pelo governo federal em 1985 é executado pela Eletrobras, com recursos da empresa, da Reserva Global de Reversão (RGR) e de entidades internacionais.
} 
possível obter dados como quantidade e tipos de luminária e lâmpadas, além dos planos futuros previstos para o mesmo.

\subsubsection{Levantamento em campo}

A coleta de informações em campo tem os seguintes objetivos:

a) Identificação das características técnicas e operativas de todos os componentes que existem no sistema de IP, envolvendo medições de tensão, corrente e fotometria, nos seguintes locais:

- Medição de tensão: nas saídas dos transformadores e finais dos circuitos secundários;

- Medição de corrente: em pontos de referência de cada circuito, que possa ser usado futuramente como ponto de monitoramento de carga.

- Medição fotométrica: ao longo da linha longitudinal entre pontos de IP,

O procedimento de medição de grandezas elétricas permitirá criar padrões de amostragem e avaliação das condições dos equipamentos presentes na rede, além de permitir a identificação imediata de problemas associados à qualidade da energia fornecida, que interfere diretamente na operação da rede de iluminação e no ciclo de vida útil de seus componentes, subsidiando o gestor para que exija as devidas correções junto à Concessionária.

b) Cadastramento ponto a ponto dos componentes identificados.

- O cadastramento ponto a ponto se dá pela observação e catalogação criteriosa de tudo que existe no ponto de iluminação. Nessa etapa o cadastrador deve star munido de instrumentos de coleta, tipo coletor PDA, que permitam não só o armazenamento prévio de informações já existentes do ponto de IP como também a identificação fotográfica do mesmo.

c) Quantificar e posicionar geograficamente o ponto de IP.

- Nessa etapa o cadastrador necessita confirmar/corrigir a posição georeferenciada do ponto de IP em razão das informações contidas na base georeferenciada da Prefeitura e da concessionária de energia elétrica local, de preferência com o mesmo instrumento PDA utilizado para o cadastramento ponto a ponto.

d) Identificar a largura da via pública.

- A medição da largura da rua é feita com uma trena entre o limite do leito carroçável e a calçada, considerando que o poste esteja a cerca de 50 centímetros para dentro da calçada. Caso o poste esteja acima de 50 centímetros, a medição 
deverá ser acrescida dessa diferença entre o poste e o limite da calçada com o leito carroçável.

e) Confirmar/Identificar os monumentos e marcos históricos.

- O cadastrador deve ser devidamente instruído para a identificação dos monumentos e marcos históricos ainda não iluminado da cidade objeto do levantamento, considerando o enfoque que o gestor do acervo de IP deseja dar para esses equipamentos públicos, frente ao perfil da cidade. Dependendo da evidência que deseja dar a esses monumentos e marcos, a identificação dos mesmos precisa ser feita com uma visão arquitetônica, portanto o cadastrador necessita estar treinado para tal atividade.

f) Confirmar/Identificar obras de arte.

- A identificação de obras de arte ainda não iluminada também necessita de um treinamento de visão arquitetônica ao cadastrador, tendo em vista que a obra de arte pode passar despercebida pelo cadastrador e o gestor público de IP perderá a oportunidade de criar uma iluminação que evidencie essa obra de arte que valoriza o espaço público não só durante o dia, mas especialmente à noite.

g) Confirmar/Identificar pontos de interesse público em períodos noturnos (Escolas, Faculdades, Hospitais, Teatros, etc.).

- Seja qual for o perfil da cidade, agrícola, industrial, comercial, etc., sempre haverá escolas, hospitais, cinemas, edificações públicas ou privadas de funcionamento noturno, etc. que provocam a circulação noturna de pessoas, portanto é necessário que se identifique esses pontos na cidade e, se possível, o trajeto de deslocamento dessas pessoas entre pontos de transporte público (ônibus, metrô, etc.) e esses pontos de interesse público.

As condições técnicas são obtidas a partir de inspeções visuais e medições fotométricas, de forma que, ao final do levantamento, é possível obter as informações que permitam identificar o funcionamento do sistema de IP. Conhecendo também as condições de utilização dos espaços públicos pela população, é possível reconhecer e identificar a dinâmica de utilização das vias públicas, que impactam no uso do sistema de IP. 


\subsection{Etapa de controle de qualidade}

Um levantamento de campo, por menor que seja, exige a adoção de um controle de qualidade que garanta que as informações coletadas sejam fidedignas com a realidade encontrada em campo, especialmente se houverem vários cadastradores trabalhando simultaneamente e com grande quantidade de pontos de IP a serem levantados. O risco de erros é grande e precisa ser mitigado.

Neste trabalho em questão, foram utilizados os conceitos contidos na norma NBR 5426 - Planos de Amostragem e Procedimentos na Inspeção por Atributos.

Os ativos e seus respectivos atributos são inspecionados através de amostragens, verificando-se as inconsistências de cada entidade através dos erros de um ou mais de seus atributos.

Os critérios estatísticos utilizados em cada amostra indicaram o "aceite" ou "rejeite" do lote produzido.

Para que se possa entender a terminologia utilizada no controle de qualidade é necessário definir os elementos e seus conjuntos, como a seguir:

- Inspeção por Atributos - Inspeção segundo a qual a unidade de produto é classificada como defeituosa ou não.

- Unidade de Produto - Elemento de referência na inspeção. Ex.: poste, equipamentos, condutor de rede de IP, condutor de rede secundária etc.

- Atributo - Uma das características da unidade de produto.

Ex.: Produto "poste" - Atributo: coordenada, tipo, altura, esforço etc.

- Unidade de Produto Defeituosa: Falta de conformidade a qualquer dos atributos especificados.

- Lote de Inspeção: Conjunto de unidades de produto a ser amostrado para verificar conformidade com as exigências de aceitação.

- NQA: Nível de Qualidade Aceitável - Máxima porcentagem defeituosa que para fins de inspeção por amostragem, pode ser considerada satisfatória como média de um processo. 
A proposição de definição da qualidade mínima aceitável, que foi adotada para esse estudo, seguiu os critérios de aceitação abaixo:

- Plano de Amostragem: Simples;

- Regime de Inspeção: Normal;

- Nível Geral de Inspeção: II;

- Nível de Qualidade Aceitável: 2,5\%;

- Tamanho do Lote: de 1201 a 3200 pontos.

Após definir uma amostra aleatória, é enviada aos locais de auditoria para analisar a qualidade do levantamento feito, posteriormente serão tabulados os itens identificados como "conformes" e "não conformes".

Quando os lotes não atenderem aos padrões definidos pela norma, haverá a rejeição da amostra, os lotes serão devolvidos para as respectivas equipes de campo, responsáveis pelos lotes rejeitados, que deverão executar os ajustes necessários, ou novo levantamento do lote por equipe diferente daquela que fez o primeiro levantamento.

Posteriormente, amostra rejeitada é refeita e no caso da amostra aceita, é refeito apenas os elementos que foram rejeitados.

Considerando que o sistema de IP é dinâmico e sofre constantes interferências do meio em que se encontra, é necessária uma constante revisão dos atributos já cadastrados, de tal forma que ao final do estudo se pode afirmar que o cadastramento está atualizado e fiel às características encontradas em campo. Para que isso seja possível todos que operam o sistema de IP, sejam eletricistas, técnicos, engenheiros, etc. devem ser avisados da existência de um trabalho de cadastramento em andamento e que qualquer ação no sistema de IP, seja de manutenção, expansão ou melhoria, deve ser informado, para que essas ações sejam introduzidas no cadastro em desenvolvimento. Da mesma forma, identificar eventuais alterações ou inclusões no sistema viário ou nas nomenclaturas identificadas durante a execução dos serviços, que estiverem divergentes ou não disponíveis na base cartográfica disponibilizada.

\subsection{Etapa de análise de dados}

Com todos os dados coletados em mãos, é possível analisar o nível de modernização do parque de IP, permitindo assim estudos que visam à adoção de tecnologias mais modernas e 
eficientes, com uma evolução na qualidade do serviço de iluminação e ganhos diretos com a redução no consumo de energia elétrica, visto que a evolução das tecnologias utilizadas nos sistemas de iluminação permite que se alcance maiores níveis de iluminamento, com potências cada vez menores.

Também é possível verificar o perfil de anomalias apresentadas nos levantamentos de campo, identificando aquelas mais significativas e viciosas que podem ser objetos de soluções específicas, que nem sempre estão vinculadas ao sistema de IP. Como exemplo mais comum, podemos citar as interferências com arborização, que sem dúvida nenhuma é um dos grandes vilões da IP, que muitas vezes interfere e/ou impede que o índice luminoso definido em norma seja respeitado. Esse quesito é conflitante com o crescente apelo ambiental que a sociedade hoje impõe para a proteção da vegetação existente, o que dificulta a poda de árvores para desimpedir o fluxo luminoso, o que acaba confrontando com outros quesitos muito valorados pela sociedade como "segurança" e "lazer", que são parâmetros intimamente ligados a IP, que essa mesma sociedade cobra das autoridades.

Dessa forma, é possível confrontar as informações já recolhidas nos escritórios, com as encontradas em campo, permitindo inclusive mostrar a dinâmica das modificações que o sistema de IP está submetido, tendo em vista que existem cidades, com alto grau de modificações viárias durante o ano, que requisitam uma elevada vigilância para que nada deixe de ser incluída na base cadastral.

Para consolidar a coleta de dados em campo, se utilizou uma planilha de dados, similar ao exemplo da tabela 4, que serviu de base de acompanhamento da evolução dos levantamentos. 
Tabela 4: Planilha de coleta de dados em campo

CIDADE

CONCESIONÁRIA LOCA

QUANTIDADE DE PONTOS DE IP:

QUANTIDADE DE KWh faturado:

\begin{tabular}{|c|c|c|c|c|c|c|c|c|c|c|c|c|c|c|c|c|c|c|c|c|c|c|}
\hline \multirow[b]{2}{*}{ ÁREA } & \multirow[b]{2}{*}{ REGIÃO } & \multicolumn{2}{|c|}{ QUADRICULAS } & \multirow[b]{2}{*}{ \% Levantado } & \multicolumn{2}{|c|}{\begin{tabular}{|l} 
Pontos de IP \\
\end{tabular}} & \multirow[b]{2}{*}{$\%$ Levantado } & \multicolumn{2}{|c|}{ Postes } & \multirow[b]{2}{*}{ \% Levantado } & \multicolumn{2}{|c|}{\begin{tabular}{|l|} 
Transformadores \\
\end{tabular}} & \multirow[b]{2}{*}{ \% Levantado } & \multicolumn{2}{|c|}{\begin{tabular}{|l} 
Condutores \\
\end{tabular}} & \multirow[b]{2}{*}{$\%$ Levantado } & \multicolumn{2}{|c|}{\begin{tabular}{|l} 
Luminárias \\
\end{tabular}} & \multirow[b]{2}{*}{ \% Levantado } & \multicolumn{3}{|c|}{ Mediçôs } \\
\hline & & Total & Finalizadas & & \begin{tabular}{|c} 
№ Cadastro \\
Original \\
\end{tabular} & № Levantado & & \begin{tabular}{|c} 
No Cadastro \\
Original \\
\end{tabular} & № Levantado & & \begin{tabular}{|c|} 
No Cadastro \\
Original \\
\end{tabular} & \begin{tabular}{|l|} 
№ Levantado \\
\end{tabular} & & \begin{tabular}{|c|} 
No Cadastro \\
Original \\
\end{tabular} & \begin{tabular}{|l|} 
№ Levantado \\
\end{tabular} & & \begin{tabular}{|c|} 
No Cadastro \\
Original \\
\end{tabular} & № Levantado & & \begin{tabular}{|c|} 
Tensão \\
(V) médio
\end{tabular} & $\begin{array}{l}\text { Corrente } \\
\text { (A) médio }\end{array}$ & $\begin{array}{c}\text { Luminotéénico } \\
\text { (Lux) médio }\end{array}$ \\
\hline \multirow{3}{*}{1} & \begin{tabular}{|l|} 
Bairro 1.1 \\
\end{tabular} & & & \#DIV/0! & \begin{tabular}{|l|}
$\mathrm{xx}$ \\
\end{tabular} & yy & \#VALOR! & \begin{tabular}{|l|}
$x x$ \\
\end{tabular} & yy & \#VALOR! & \begin{tabular}{|l|}
$x x$ \\
\end{tabular} & yy & \#VALOR! & \begin{tabular}{|l|}
$\mathrm{xx}$ \\
\end{tabular} & yy & \#VALOR! & \begin{tabular}{|l|}
$\mathrm{xx}$ \\
\end{tabular} & yy & \#VALOR! & & & \\
\hline & Bairro 1.2 & & & \#DIV/0! & $x x$ & $x y$ & \#VALOR! & $x \mathrm{x}$ & $x y$ & \#VALOR! & $x x$ & $x y$ & \#VALOR! & $x x$ & $x y$ & \#VALOR! & $\mathrm{xx}$ & $x y$ & \#VALOR! & & & \\
\hline & Bairro 1.3 & & & \#DIV/0! & $x x$ & $x x$ & \#VALOR! & $x x$ & $x x$ & \#VALOR! & $x x$ & $x x$ & \#VALOR! & $x x$ & $x x$ & \#VALOR! & $x x$ & $x x$ & \#VALOR! & & & \\
\hline & $\begin{array}{l}\text { TOTAL } \\
\end{array}$ & 0 & 0 & \#DIV/0! & 0 & 0 & \#DIV/0! & 0 & 0 & \#DIV/0! & 0 & 0 & \#DIV/0! & 0 & 0 & \#DIV/0! & 0 & 0 & \#DIV/0! & 0 & 0 & 0 \\
\hline \multirow{5}{*}{2} & Bairro 2.1 & & & \#DIV/0! & $x y$ & $x x$ & \#VALOR! & $x y$ & $x x$ & \#VALOR! & $x y$ & $x x$ & \#VALOR! & $x y$ & $x x$ & \#VALOR! & $x y$ & $x x$ & \#VALOR! & & & \\
\hline & \begin{tabular}{|l|} 
Bairro 2.2 \\
\end{tabular} & & & \#DIV/0! & $x x$ & $x x$ & \#VALOR! & $x x$ & $x x$ & \#VALOR! & $x x$ & $x x$ & \#VALOR! & $x x$ & $\mathrm{xx}$ & \#VALOR! & $x x$ & $x x$ & \#VALOR! & & & \\
\hline & \begin{tabular}{|l|} 
Bairro 2.3 \\
\end{tabular} & & & \#DIV/0! & $y x$ & $y x$ & \#VALOR! & $y x$ & $y x$ & \#VALOR! & $y x$ & $y x$ & \#VALOR! & $y x$ & $y x$ & \#VALOR! & $y x$ & $\mathrm{yx}$ & \#VALOR! & & & \\
\hline & \begin{tabular}{|l|} 
Bairro 2.4 \\
\end{tabular} & & & \#DIV/0! & $x y$ & $x y$ & \#VALOR! & $x y$ & $x y$ & \#VALOR! & $x y$ & $x y$ & \#VALOR! & $x y$ & $x y$ & \#VALOR! & $x y$ & $x y$ & \#VALOR! & & & \\
\hline & Bairro 2.5 & & & \#DIV/0! & $x x$ & $\mathrm{xx}$ & \#VALOR! & $\mathrm{xx}$ & $x x$ & \#VALOR! & $x x$ & $x x$ & \#VALOR! & $x x$ & $x x$ & \#VALOR! & $x x$ & $x x$ & \#VALOR! & & & \\
\hline & TOTAL & 0 & 0 & \#DIV/0! & 0 & 0 & \#DIV/0! & 0 & 0 & \#DIV/0! & 0 & 0 & \#DIV/0! & 0 & 0 & \#DIV/0! & 0 & 0 & \#DIV/0! & 0 & 0 & 0 \\
\hline \multirow{8}{*}{3} & \begin{tabular}{|l|} 
Bairro 3.1 \\
\end{tabular} & & & \#DIV/0! & $x y$ & xy & \#VALOR! & $x y$ & xy & \#VALOR! & xy & $x y$ & \#VALOR! & $x y$ & $x y$ & \#VALOR! & $x y$ & $x y$ & "\#VALOR! & & & \\
\hline & \begin{tabular}{|l|} 
Bairro 3.2 \\
\end{tabular} & & & \#DIV/0! & $x x$ & $x x$ & \#VALOR! & $x x$ & $x x$ & \#VALOR! & $x x$ & $x x$ & \#VALOR! & $x x$ & $x x$ & \#VALOR! & $x x$ & $x x$ & \#VALOR! & & & \\
\hline & \begin{tabular}{|l|l} 
Bairro 3.3 \\
\end{tabular} & & & \#DIV/0! & $y x$ & $y x$ & \#VALOR! & $y x$ & $y x$ & \#VALOR! & $y x$ & $y x$ & \#VALOR! & $y x$ & $y x$ & \#VALOR! & $y x$ & $y x$ & \#VALOR! & & & \\
\hline & \begin{tabular}{|l|} 
Bairro 3.4 \\
\end{tabular} & & & \#DIV/0! & $x y$ & $x y$ & \#VALOR! & $x y$ & $x y$ & \#VALOR! & $x y$ & $x y$ & \#VALOR! & $x y$ & $x y$ & \#VALOR! & $x y$ & $x y$ & \#VALOR! & & & \\
\hline & \begin{tabular}{|l|l|} 
Bairro 3.5 \\
\end{tabular} & & & \#DIV/0! & $x x$ & $x x$ & \#VALOR! & $x x$ & $x x$ & \#VALOR! & $x x$ & $x x$ & \#VALOR! & $x x$ & $x x$ & \#VALOR! & $x x$ & $x x$ & \#VALOR! & & & \\
\hline & \begin{tabular}{|l|} 
Bairro 3.6 \\
\end{tabular} & & & \#DIV/0! & $y x$ & $y x$ & \#VALOR! & $y x$ & $y x$ & \#VALOR! & $y x$ & $y x$ & \#VALOR! & $y x$ & $y x$ & \#VALOR! & $y x$ & $y x$ & \#VALOR! & & & \\
\hline & \begin{tabular}{|l} 
Bairro 3.7 \\
\end{tabular} & & & \#DIV/0! & $x y$ & $x y$ & \#VALOR! & $x y$ & $x y$ & \#VALOR! & $x y$ & $x y$ & \#VALOR! & $x y$ & $x y$ & \#VALOR! & $x y$ & $x y$ & \#VALOR! & & & \\
\hline & TOTAL & 0 & 0 & \#DIV/0! & 0 & 0 & \#DIV/O! & 0 & 0 & \#DIV/0! & 0 & 0 & \#DIV/0! & 0 & 0 & \#DIV/0! & 0 & 0 & \#DIV/0! & 0 & 0 & 0 \\
\hline \multirow{10}{*}{$\mathrm{n}$} & \begin{tabular}{|l|l|} 
Bairro 4.1 \\
\end{tabular} & & & \#DIV/0! & $x y$ & $x y$ & \#VALOR! & $x y$ & $x y$ & \#VALOR! & $x y$ & $x y$ & \#VALOR! & $x y$ & $x y$ & \#VALOR! & $x y$ & $x y$ & \#VALOR! & & & \\
\hline & \begin{tabular}{|l|} 
Bairro 4.2 \\
\end{tabular} & & & \#DIV/0! & $x x$ & $x x$ & \#VALOR! & $x x$ & $x x$ & \#VALOR! & $x x$ & $x x$ & \#VALOR! & $x x$ & $x x$ & \#VALOR! & $x x$ & $x x$ & \#VALOR! & & & \\
\hline & \begin{tabular}{|l} 
Bairro 4.3 \\
\end{tabular} & & & \#DIV/0! & $y x$ & $y x$ & \#VALOR! & $y x$ & $y x$ & \#VALOR! & $y x$ & $y x$ & \#VALOR! & $y x$ & $y x$ & \#VALOR! & $y x$ & $y x$ & \#VALOR! & & & \\
\hline & \begin{tabular}{|l|} 
Bairro 4.4 \\
\end{tabular} & & & \#DIV/O! & $x y$ & $x y$ & \#VALOR! & $x y$ & $x y$ & \#VALOR! & $x y$ & $x y$ & \#VALOR! & $x y$ & $x y$ & \#VALOR! & $x y$ & $x y$ & \#VALOR! & & & \\
\hline & \begin{tabular}{|l|} 
Bairro 4.5 \\
\end{tabular} & & & \#DIV/0! & $x x$ & $x x$ & \#VALOR! & $x x$ & $x x$ & \#VALOR! & $x x$ & $x x$ & \#VALOR! & $x x$ & $x x$ & \#VALOR! & $x x$ & $x x$ & \#VALOR! & & & \\
\hline & \begin{tabular}{|l|l} 
Bairro 4.6 \\
\end{tabular} & & & \#DIV/0! & $y x$ & $y x$ & \#VALOR! & $y x$ & $y x$ & \#VALOR! & $y x$ & $y x$ & \#VALOR! & $y x$ & $y x$ & \#VALOR! & $y x$ & $y x$ & \#VALOR! & & & \\
\hline & \begin{tabular}{|l|} 
Bairro 4.7 \\
\end{tabular} & & & \#DIV/O! & $x y$ & $x y$ & \#VALOR! & $x y$ & $x y$ & \#VALOR! & $x y$ & $x y$ & \#VALOR! & $x y$ & $x y$ & \#VALOR! & $x y$ & $x y$ & \#VALOR! & & & \\
\hline & \begin{tabular}{|l|} 
Bairro 4.8 \\
\end{tabular} & & & \#DIV/0! & $x x$ & $x x$ & \#VALOR! & $x x$ & $x x$ & \#VALOR! & $x x$ & $x x$ & \#VALOR! & $x x$ & $x x$ & \#VALOR! & $x x$ & $x x$ & \#VALOR! & & & \\
\hline & \begin{tabular}{|l|} 
Bairro 4.9 \\
\end{tabular} & & & \#DIV/0! & $y x$ & $y x$ & \#VALOR! & $y x$ & $y x$ & \#VALOR! & $y x$ & $y x$ & \#VALOR! & $y x$ & $y x$ & \#VALOR! & $y x$ & $y x$ & \#VALOR! & & & \\
\hline & \begin{tabular}{|l|} 
Bairro 4.10 \\
\end{tabular} & & & \#DIV/0! & $x y$ & $x y$ & \#VALOR! & $x y$ & $x y$ & \#VALOR! & $x y$ & $x y$ & \#VALOR! & $x y$ & $x y$ & \#VALOR! & $x y$ & $x y$ & \#VALOR! & & & \\
\hline \multicolumn{2}{|c|}{ TOTAL } & 0 & 0 & \#DIV/0! & 0 & 0 & \#DIV/0! & 0 & 0 & \#DIV/0! & 0 & 0 & \#DIV/0! & 0 & 0 & \#DIV/0! & 0 & 0 & \#DIV/0! & 0 & 0 & 0 \\
\hline \multicolumn{2}{|c|}{ TOTAL GERAL } & 0 & 0 & \#DIV/0! & 0 & 0 & \#DIV/0! & 0 & 0 & \#DIV/0! & 0 & 0 & \#DIV/0! & 0 & 0 & \#DIV/0! & 0 & 0 & \#DIV/0! & 0 & 0 & 0 \\
\hline
\end{tabular}

Fonte: Autor, 2014 


\section{VALIDAÇÃO DA METODOLOGIA}

A fim de validar a aplicabilidade da metodologia aqui apresentada, foi adotado um campo de prova em uma região metropolitana de São Paulo.

\subsection{Estudo da Região}

A região estudada compreende uma área de $26,5 \mathrm{~km}^{2}$, habitada por 344.632 pessoas. A escolha dessa região deve-se ao seu perfil comercial e residencial, que pelo seu porte, pode ser comparado a muitas cidades de médio porte existentes no Brasil com perfil semelhante.

A fundação da região estudada data do século XVIII, têm uma área de $26,5 \mathrm{Km}^{2}$, com uma população levantada pelo último senso 2010 com 344.632 habitantes. Tem perfil identificado como comercial e residencial. Mantém diversos pontos de interesse noturno da população, como: universidades, parques, teatros e atividades esportivas noturnas, como ciclismo, skatismo, pedestrianismo, etc. Por pertencer à região metropolitana de São Paulo, possui uma intensa vida noturna.

\subsection{Etapa de Planejamento}

Para início dos trabalhos é necessário primeiro efetuar a junção das bases georeferenciadas encontradas na Concessionária de Energia e na Prefeitura. Considerando que ambas as bases, contém informações que podem ser usadas como referência, tendo em vista que se completam, é ideal adotar a estratégia de mesclar as duas. Após a conversão dos sistemas de coordenadas e correções das distorções encontradas nas bases, é possível obter uma base georeferenciada mais atualizada, considerando as informações necessárias para iniciar os trabalhos de levantamento em campo.

A fim de definir os parâmetros a serem levantados, foram feitas diversas reuniões junto a componentes da equipe de gestão da IP daquela região em estudo. Este 
procedimento é importante para entendimento dos processos de gestão de atendimento ao cliente (Call Center), materiais, manutenção, ampliação e remodelação do parque de IP

\subsection{Etapa de Levantamentos}

\subsubsection{Levantamento de documentações}

\section{Na Prefeitura}

As pesquisas efetuadas na Prefeitura em estudo foram encontrados os seguintes documentos:

- Base Cartográfica da cidade com data de elaboração de 1995, constituída de diversos layers, porém, o que aproveitamos foram os seguintes:

- Lotes

- Arruamentos

- Curva de nível

- Edificações

- Ferrovias

- Quadras formadas pelos lotes

- Quadras formadas pelos meios-fios

- Malha de Imagens Aéreas 1:1000 e 1:5000

- Eixos de Logradouros

Sistema de Coordenadas: SAD69, UTM 23S.

- Últimos projetos Reluz concluídos

- Últimos projetos de expansão concluídos

\section{Na Concessionária}

As pesquisas efetuadas na Concessionária local em estudo foram encontrados os seguintes documentos: 
- Base Cartográfica da cidade, constituída de diversos layers, porém o que aproveitamos foram os seguintes:

- Quadras viárias

- Principais prédios

- Limites municipais

- Detalhes construtivos: Ex.: Aeroportos, etc.

- Praças, Jardins e Canteiros centrais.

- Rios e Lagos

- Postes de energia

- Principais estradas e rodovias

- Eixo de logradouro completo

Sistema de Coordenadas: Córrego Alegre Customizado, UTM 23S.

As informações geográficas fornecidas pela concessionária possuíam dados sobre as características da rede de distribuição de energia, incluindo os postes, que foram importantes para a extração de atributos como: tipo, altura e carga admissível dos postes. Estes dados foram úteis na comparação com os levantados em campo, porém só foram utilizados em casos onde a identificação em campo não foi possível. Com relação aos eixos de logradouros, apenas a base da concessionária estava completa, motivo pelo qual optamos por utilizar essa base como mapa de fundo do WebGIS ${ }^{10}$.

\subsubsection{Levantamento em campo}

Considerando o perfil da região estudada, o intenso tráfego de veículos e o fluxo de pessoas nas vias públicas, especialmente no período diurno, para efetuar os levantamentos em campos, foram tomadas as seguintes ações:

- Dividiu-se a cidade em quadrículas, para facilitar o controle dos trabalhos e a apuração da qualidade dos levantamentos;

\footnotetext{
${ }^{10}$ WEBGIS: É um (SIG) sistema de informações geográficas básicas que permite ao usuário consultar informações georeferenciadas e tabulares sobre o município de modo interativo, através da manipulação de diferentes níveis de informação (camadas), de acordo com seu interesse e necessidade.
} 
- Foi elaborado um intenso treinamento com as equipes de campo referente ao reconhecimento dos atributos que seriam levantados, de forma a minimizar possíveis erros de identificação;

- Foram utilizados equipamentos de levantamento portáteis (PDAs), onde foi possível carregar parte da base cadastral da cidade onde a respectiva equipe iria fazer o levantamento;

- Os dados coletados eram descarregados nas bases computacionais diariamente, quando era iniciado o controle de qualidade.

Os resultados do levantamento em campo estão apresentados no item de "Relatório Técnico".

\subsection{Etapa de garantia de qualidade}

Para garantir que todos os dados coletados refletiam a realidade em campo, antes de serem inseridos na base cadastral do município, passavam pela rotina de controle de qualidade, já explicado anteriormente. Para tanto, foram atribuídas ao sistema computacional, algumas regras de confiabilidade que impediam a inserção de dados que não combinavam entre si, como por exemplo, uma lâmpada que não cabe dentro de uma determinada luminária. Após a primeira aprovação de qualidade dos dados inseridos, seguia-se a comparação fotográfica, onde se comparavam os dados inseridos na base com as fotos tiradas em campo, pertinentes ao ponto cadastrado. Dessa forma foi possível efetuar correções de inconsistências entre o que constava na base cadastral e os dados levantados em campo.

\subsection{Etapa de análise dos dados}

Depois de concluído um bairro, com todos os dados levantados e devidamente inseridos na base cadastral, iniciava-se a análise das informações, a fim de obter respostas estatísticas que pudessem ajudar na elaboração do Relatório Técnico. 


\subsubsection{Relatório Técnico}

O relatório técnico tem a função de demonstrar, com dados levantados em campo, a situação do sistema de IP, considerando as características técnicas identificadas, abordando a situação quantitativa e qualitativa do acervo.

Os atributos escolhidos para incorporar a esse relatório foram os seguintes:
a) Transformadores
b) Comandos
c) Condutores
d) Postes
e) Braços
f) Luminárias
g) Lâmpadas

a) Transformadores

Foi identificado um total de 899 equipamentos, sendo que a potência mais utilizada é de $10 \mathrm{KVA}(52,5 \%)$, conforme tabela 5.

Tabela 5: Levantamento de transformadores de IP

\begin{tabular}{cc}
\hline Potência (KVA) & Quantidade \\
\cline { 3 - 3 } 75 & 7 \\
7,5 & 165 \\
10 & 472 \\
15 & 62 \\
25 & 46 \\
Ilegível & 147 \\
TOTAL & $\mathbf{8 9 9}$ \\
\hline
\end{tabular}

Fonte: Autor, 2013

\section{Caracterização das anomalias}

Apesar das anomalias serem momentâneas, considerando que existem equipes de manutenção em ação na região, as informações podem ser usadas para acompanhamento e monitoramento do tempo de regularização das ocorrências e mensurar a eficiência dessas equipes de manutenção. As anomalias identificadas estão descritas na tabela 6 e representadas estatisticamente no gráfico 4. 
Tabela 6: Anomalias em transformadores de IP

\begin{tabular}{lc}
\hline Anomalia & Qtd. \\
\hline Carcaça Enferrujada & 7 \\
Trafo Desativado & 2 \\
Vazamento de Óleo & 1 \\
Total & $\mathbf{1 0}$ \\
\hline
\end{tabular}

Fonte: Autor, 2013

Gráfico 4: Percentual de anomalias em transformadores

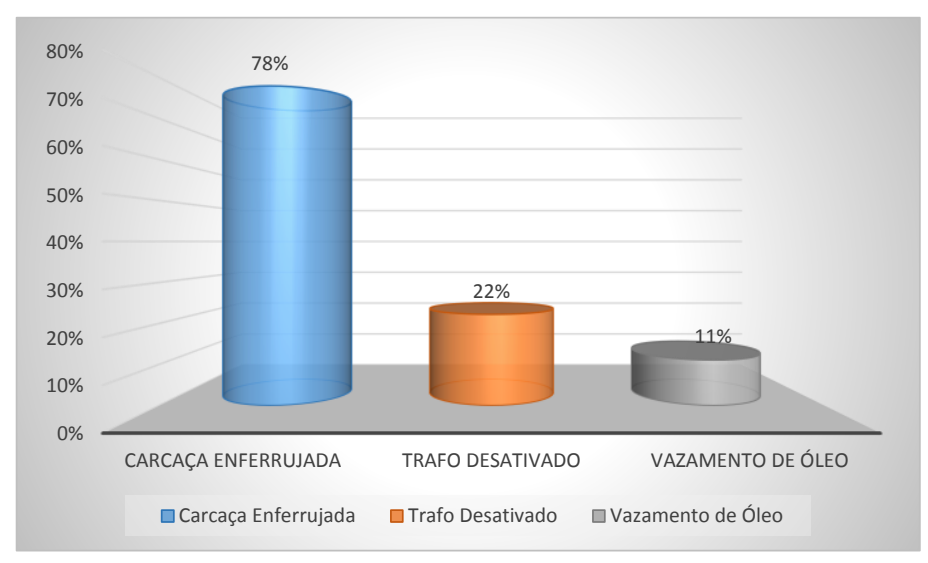

Fonte: Autor, 2013

\section{Análise Técnica}

Considerando as 10 anomalias encontradas nos 899 transformadores existentes na cidade em estudo, podemos dizer que existem 8 (80\%) equipamentos que estão em processo de corrosão e vazamento de óleo, caracterizando falta de manutenção, com possibilidades de perda da condição operativa, e podem levar a ocorrências emergenciais, portanto precisam de ações preventivas de manutenção.

\section{b) Comandos de IP}

Foi identificado um total de 2.773 equipamentos responsáveis pelo comando da IP na região analisada, conforme tabela 7 . 
Tabela 7: Levantamento de equipamentos de IP:

\begin{tabular}{|c|c|}
\hline Equipamentos & Qtd. \\
\hline Relê Fotoelétrico & 1.009 \\
\hline Chave Magnética & 929 \\
\hline Chave de Proteção 70a & 500 \\
\hline Chave de Proteção 50a & 131 \\
\hline Chave de proteção $100 \mathrm{a}$ & 103 \\
\hline Chave de Proteção Ilegível & 101 \\
\hline Total & 2.773 \\
\hline
\end{tabular}

Fonte: Autor, 2013

O sistema de acionamento da IP da cidade em estudo é em grupo, isto é, certa quantidade de luminárias é acionada através de um conjunto "relé fotoelétrico, chave magnética e chave de proteção", cuja divisão percentual encontra-se demonstrada no gráfico 5 .

Gráfico 5: Percentual quantitativo de equipamentos de IP

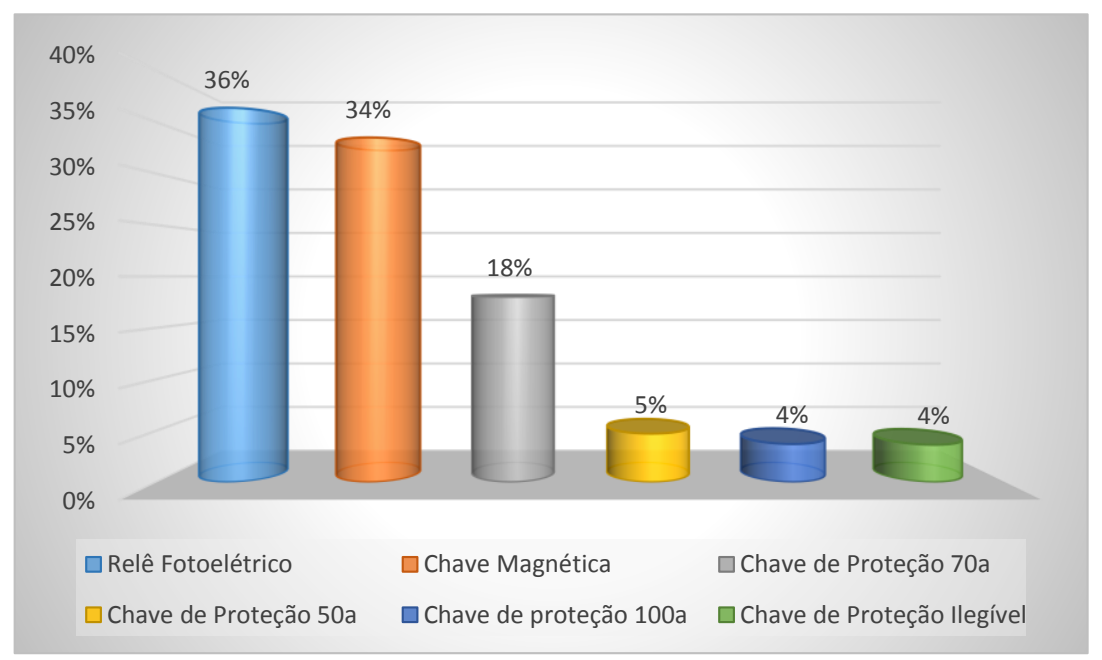

Fonte: Autor, 2013

\section{Análise Técnica}

Na cidade em estudo, a maior parte do sistema de IP existente ainda é com comando em grupo, porém existe uma forte tendência de migrar para comando individual, cuja maior vantagem é não comprometer várias luminárias quando houver falha no relé-fotoelétrico. 


\section{c) Condutores de IP}

Foram cadastrados 416.302 metros de condutores destinados a IP na região em estudo, que corresponde aos seguintes tipos (Tabela 8):

Tabela 8: Quantidade de condutores de IP por tipo

\begin{tabular}{lc}
\hline \multicolumn{1}{c}{ CONDO } & QTD. (M) \\
\hline $16 \mathrm{~mm}^{2}$-Triplex & 129.448 \\
6 AWG - PVC Cobre - Verde & 121.596 \\
16 mm²-Duplex & 100.382 \\
6 AWG-PVC Cobre - Preto & 46.974 \\
$16 \mathrm{~mm}^{2}$ - PVC Cobre - Preto & 11.595 \\
$25 \mathrm{~mm}^{2}$ - PVC Cobre - Preto & 3.523 \\
$10 \mathrm{~mm}^{2}$ - PVC Aluminio - Preto & 984 \\
$10 \mathrm{~mm}^{2}$-Duplex & 768 \\
$35 \mathrm{~mm}^{2}$ - PVC Cobre - Preto & 338 \\
$10 \mathrm{~mm}^{2}-$ Triplex & 336 \\
$10 \mathrm{~mm}^{2}$ - PVC Aluminio - Verde & 271 \\
$10 \mathrm{~mm}^{2}$ - PVC Cobre - Preto & 63 \\
$25 \mathrm{~mm}^{2}$-Duplex & 23 \\
\multicolumn{1}{c}{ TOTAL } & $\mathbf{4 1 6 . 3 0 2}$ \\
\hline
\end{tabular}

Fonte: Autor, 2013

Foi identificada uma predominância de cabos multiplexados, conforme demonstrado no gráfico 6, que apresentam um desempenho melhor que os condutores singelos devido a menor interferência com arborização. Essa evidência é em razão dos trabalhos já realizados de substituição de fio 6 AWG de cobre da rede de IP, que apresentam maiores índices de rompimento devido a sua obsolescência, contudo ainda existe uma quantidade significativa desse condutor $(40,5 \%)$, onde esse trabalho ainda é necessário. 
Gráfico 6: Percentual de quantidade de condutores de IP por tipo

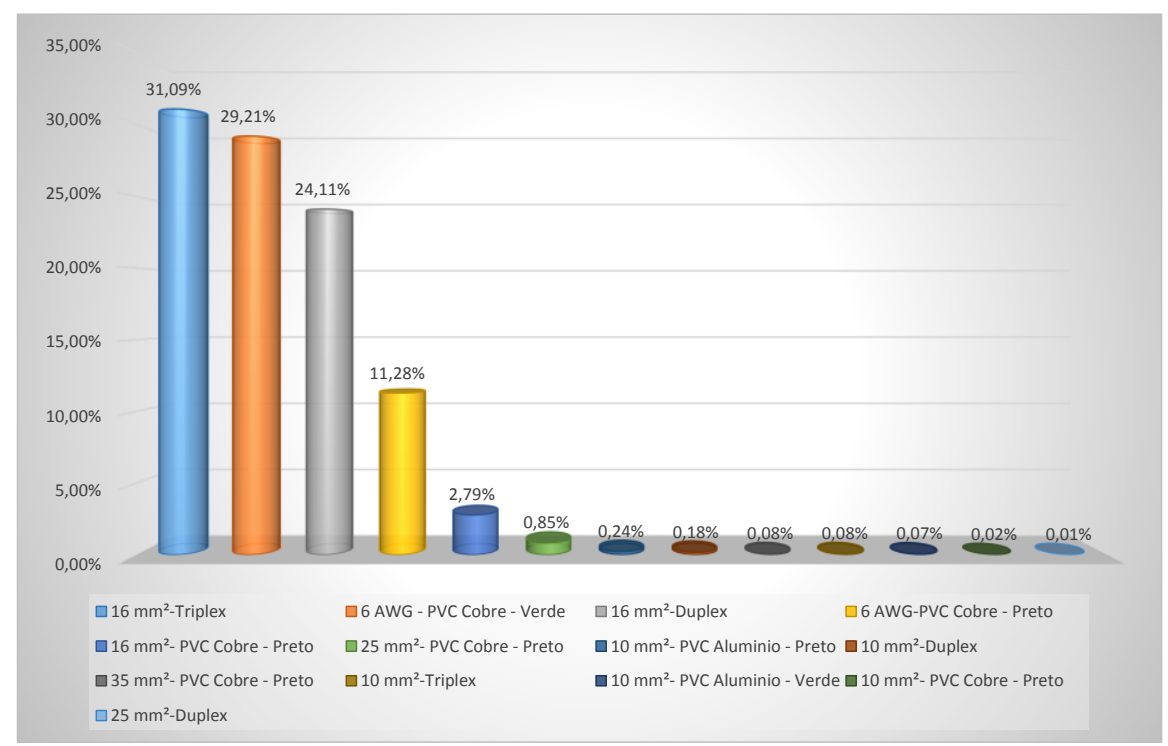

Fonte: Autor, 2013

\section{Caracterização das Anomalias}

No momento do cadastramento foram identificadas as seguintes anomalias (Tabela 9):

Tabela 9: Quantidade de anomalias em condutores por tipo

\begin{tabular}{lc}
\hline \multicolumn{1}{c}{ ANOMALIA } & QTD. \\
\hline Interferência de Arborização & 1.518 \\
Emendas Impróprias (Charruas) & 121 \\
Condutor Rompido & 12 \\
Condutor Furtado & 14 \\
Condutor Frouxo & 11 \\
Condutor Próximo de Terceiros & 2 \\
Ligação Clandestina de Terceiros & 1 \\
Objeto Pendurado na Rede & 3 \\
Falta de Conectores/Capa & 1 \\
\multicolumn{1}{c}{ TOTAL } & $\mathbf{1 . 6 8 3}$ \\
\hline
\end{tabular}

Fonte: Autor, 2013 
Gráfico 7: Percentual de anomalias em condutores de IP por tipo

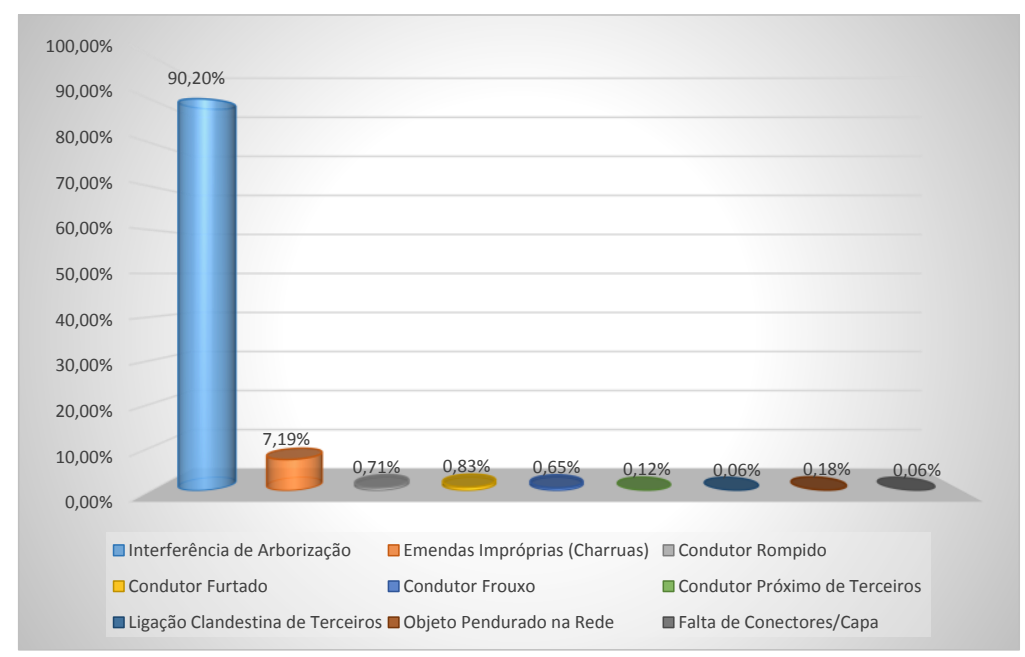

Fonte: Autor, 2013

\section{Análise Técnica}

Observa-se uma quantidade acentuada de eventos (90,20\%), pertinentes a "interferências com arborização", conforme identificado no gráfico 7. Isso se deve a um antigo problema de convívio das redes elétricas com arborização.

É imprescindível que se tenha um plano de podas de árvores, em conformidade com as legislações de preservação do verde, a fim de minimizar os contatos provocados principalmente por ventos e chuvas, que invariavelmente levam ao rompimento dos cabos e fios, não só de IP como também do sistema de distribuição de energia elétrica.

Outro ponto que aparece em menor proporção $(7,19 \%)$, mas também merece atenção são os eventos de "Emendas Impróprias", que evidenciam ações de manutenção inadequadas. Essa situação caracteriza uma necessidade de reforço no treinamento das equipes de manutenção, assim como o uso de materiais adequados aos reparos de emergência.

\section{d) Postes de IP}

Foram cadastrados 23.052 postes, distribuídos conforme descrito na tabela 10 . 
Tabela 10: Quantidade de postes por proprietários

\begin{tabular}{lc}
\hline \multicolumn{1}{c}{ PROPRIETÁRIO } & QTD. \\
\hline Postes Concessionária Energia & 19.528 \\
Postes de Aço Prefeitura & 3.522 \\
Postes Ornamentais Prefeitura & 2 \\
TOTAL & $\mathbf{2 3 . 0 5 2}$ \\
\hline
\end{tabular}

Fonte: Autor, 2013

A maior parte dos postes que sustentam o sistema de IP (84,71\%), conforme identificado no gráfico 8 , pertence à Concessionária de Energia local.

Gráfico 8: Percentual de postes por proprietários

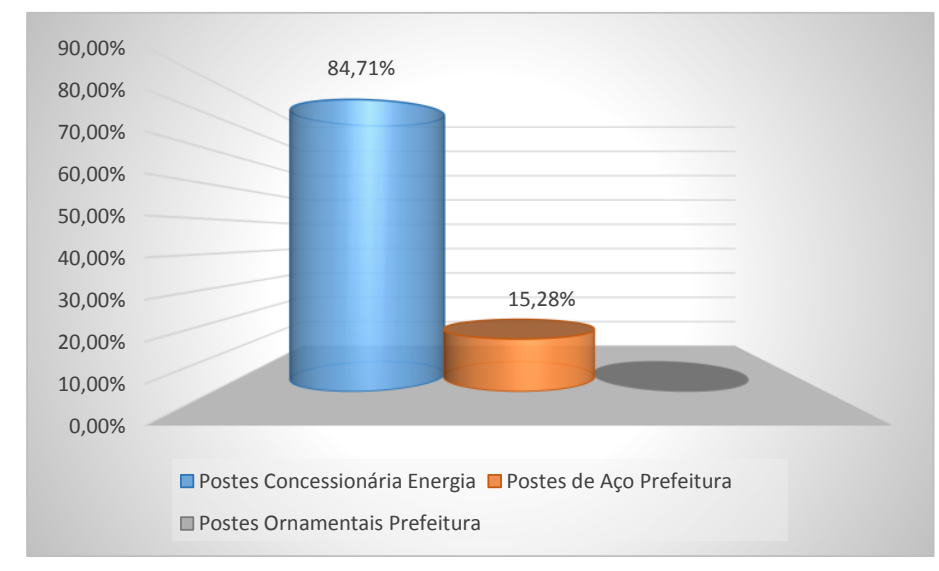

Fonte: Autor, 2013

\section{Caracterização das Anomalias}

No momento do cadastramento foram identificadas as anomalias descritas na tabela 11 .

Tabela 11: Quantidade de anomalias em postes por tipo

\begin{tabular}{|c|c|}
\hline ANOMALIA & QTD. \\
\hline Poste Com Ferragem Exposta & 405 \\
\hline Poste Torto & 202 \\
\hline Poste Trincado & 75 \\
\hline Objeto Estranho no Poste & 32 \\
\hline Poste sem Tampa & 25 \\
\hline TOTAL & 739 \\
\hline
\end{tabular}

Fonte: Autor, 2013 
Gráfico 9: Percentual de anomalias em postes por tipo:

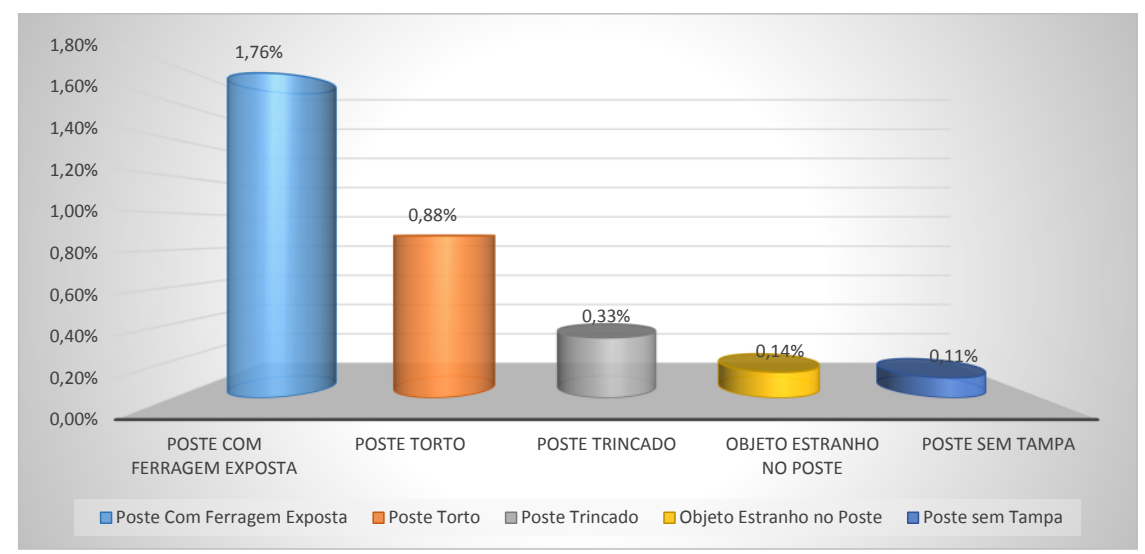

Fonte: Autor, 2013

\section{Análise Técnica}

Conforme apresentado no gráfico 9 e considerando que a grande maioria dos postes analisados pertencem à Concessionária de Energia local, que tem por obrigação regulatória manter um adequado plano de manutenção em seus ativos, as anomalias encontradas não são pertinentes a ações de manutenção por parte da Prefeitura Municipal, porém é possível contribuir com o fornecimento das informações de anomalias identificadas para ações de regularização.

\section{e) Braços de IP}

As diversas variedades de braços de sustentação das luminárias existentes na região em estudo, assim como as diversas variedades de luminárias, são frutos da constante evolução técnica pela qual passou o padrão do sistema de IP. Os braços de sustentação da luminária têm importância fundamental no sistema de IP, pois é através dele que a luminária fica posicionada em condições favoráveis para uma adequada dispersão do fluxo luminoso em uma determinada área. Geralmente o tamanho do braço está diretamente ligado à largura e utilização das ruas e avenidas. 


\section{Caracterização das anomalias}

No momento do cadastramento foram identificadas as anomalias descritas na tabela 12 .

Tabela 12: Quantidade de anomalias em braços de IP

\begin{tabular}{cc}
\hline ANOMALIA & QTD. \\
\hline Braço em Estado de Corrosão & 335 \\
Braço sem Braçadeira & 2 \\
TOTAL & $\mathbf{3 3 7}$ \\
\hline
\end{tabular}

Fonte: Autor, 2013

Gráfico 10: Percentual de anomalias em braços de IP

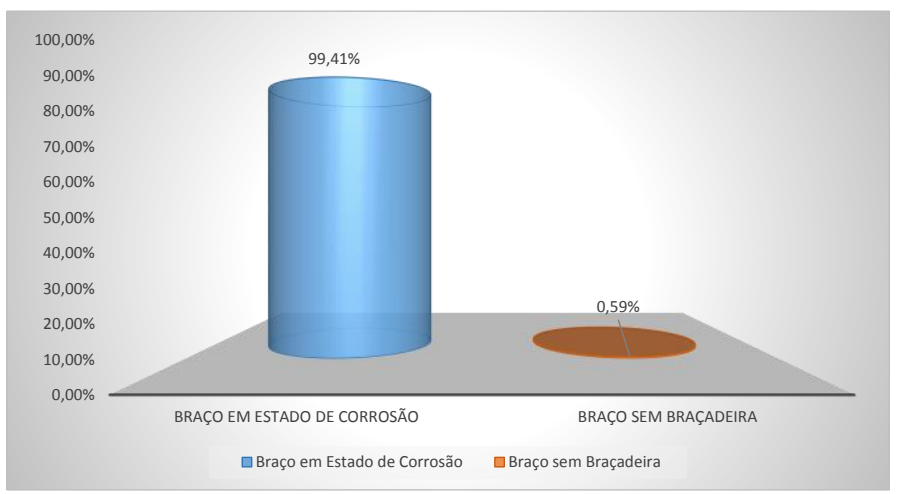

Fonte: Autor, 2013

\section{Análise Técnica}

Como observado no gráfico 10, existe uma quantidade considerável de braços em "estado de corrosão", evidenciando uma necessidade de medidas preditivas de manutenção.

Todos os braços utilizados no sistema de IP passam por um tratamento antiabrasivo, que nem sempre é suficiente para evitar por muito tempo um processo de corrosão. As equipes de manutenção devem observar a evolução do problema para que se faça sua substituição tão logo o dano avance a ponto de comprometer a sustentação do braço e assim possibilitar um possível acidente. 


\section{f) Luminárias}

Foi identificado um total de 21.370 unidades na cidade em estudo, conforme demonstrado na tabela 13 .

Tabela 13: Quantidade de luminárias por tipo

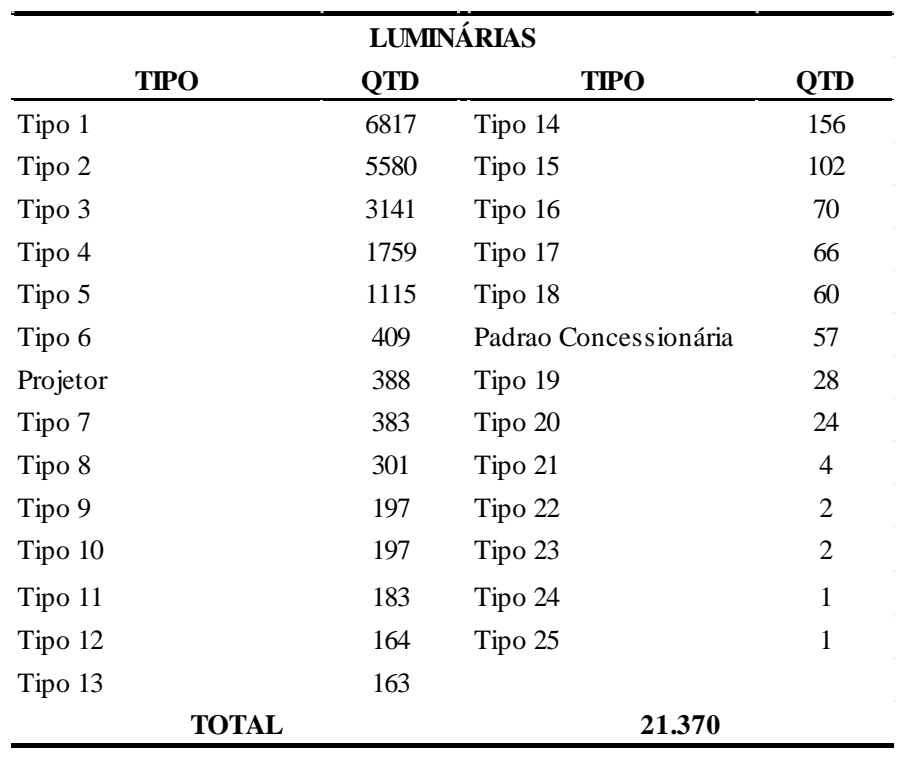

Fonte: Autor, 2013

Observa-se uma predominância das luminárias do tipo 1 (31,9\%), cujos equipamentos auxiliares são instalados externamente a luminária, seguido pela do tipo 2 $(26,11 \%)$, cujos equipamentos auxiliares são instalados dentro da luminária.

\section{Caracterização das anomalias}

Foram identificadas as anomalias descritas na tabela 14. 
Tabela 14: Quantidade de anomalias em luminárias por tipo

\begin{tabular}{lcllc}
\hline \multicolumn{1}{c}{ ANOMALIA } & QTD. & \multicolumn{1}{c}{ ANOMALIA } & QTD. \\
\cline { 5 - 5 } Vidro Quebrado/Sem Vidro & 881 & & Objeto es tranho na luminária & 11 \\
Interferência de arborização & 464 & Luminária abandonada & 10 \\
Acima da copa da arvore & 420 & Luminária faltante & 10 \\
Luminária Aberta & 352 & Vidro sujo & 8 \\
Tampa pendente (risco de cair) & 28 & Lâmpada pendente & 5 \\
Lâmpada apagada a noite & 23 & Luminária pendente/caída & 3 \\
Lâmpada acesa durante o dia & 16 & Luminária furada por balas & 2 \\
Luminária quebrada/vandalis mo & 16 & Falta Tampa & 1 \\
\multicolumn{1}{c}{ TOTAL } & & & $\mathbf{2 . 2 5 0}$ & \\
\hline
\end{tabular}

Fonte: Autor, 2013

\section{Gráfico 11: Percentual de anomalias em luminárias por tipo}

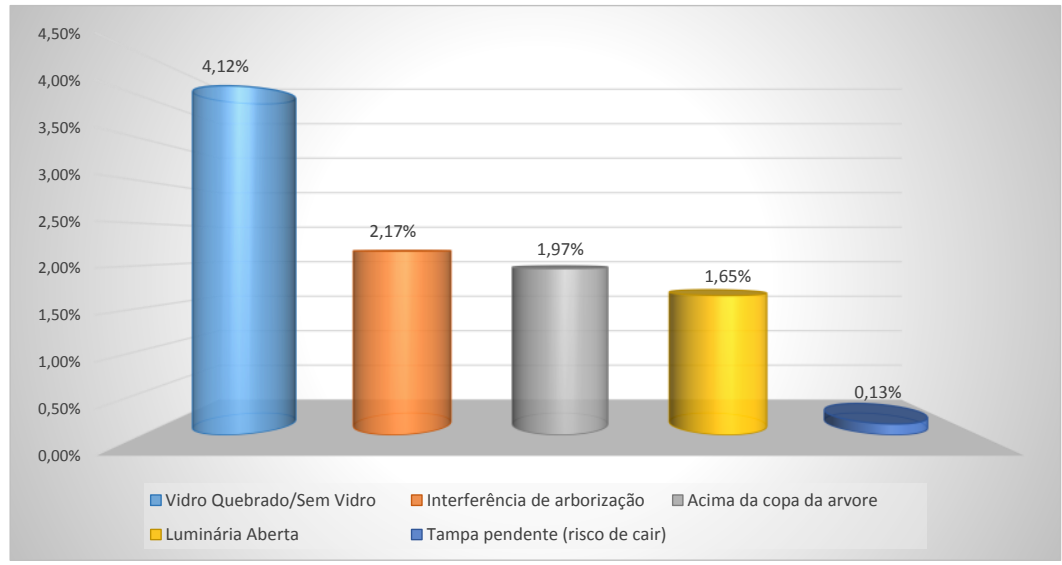

Fonte: Autor, 2013

\section{Análise Técnica}

Um dos principais componentes do sistema de IP, as luminárias têm como principal função direcionar a maior quantidade possível do fluxo luminoso emitido pelas lâmpadas para as áreas de interesse, reduzindo consequentemente a poluição luminosa causada pela dispersão de luminosidade, que poderia causar até ofuscamento aos motoristas. Ainda existe uma grande quantidade de luminárias abertas, deixando as lâmpadas expostas a choques térmicos, incidência de insetos, vandalismo, etc., reduzindo sua vida útil. Com a evolução do projeto das luminárias, foram desenvolvidos equipamentos fechados em materiais poliméricos ou vidro, que, além de uma melhor dispersão luminosa, permitem 
obter ótimos resultados devido à proximidade dos equipamentos auxiliares como reator e ignitor.

Apesar de alguns modelos de luminárias preverem que os equipamentos auxiliares sejam instalados dentro das mesmas, observou-se algumas luminárias com os equipamentos auxiliares instalados fora da luminária. Isso se explica pela necessidade das equipes de manutenção de fazerem substituições dos componentes alojados originalmente dentro das luminárias por outros incompatíveis com o alojamento, assim a substituição é feita colocando os componentes auxiliares em adaptações fora das luminárias. Essa ação é passível de comprometimento do desempenho da luminária, que foi projetada para obter seu melhor rendimento com os equipamentos auxiliares integrados a mesma, já que a distância entre a lâmpada e o conjunto reator/ignitor fica extremamente maior, requerendo um necessário redimensionamento dos mesmos.

Se considerarmos que existe na região em estudo 21.370 luminárias instaladas e que foi identificado, no momento do cadastramento, 2.284 unidades com algum problema chega-se a um percentual de anomalias de $11 \%$. Como observado no gráfico 11, as anomalias que mais se evidenciam são: vidro quebrado/sem vidro $(4,12 \%)$, interferência com arborização (2,17\%), acima da copa da árvore (1,97\%) e luminária aberta (sem cúpula) (1,65\%), indicando uma necessidade de ações de manutenção.

\section{g) Lâmpadas}

Na região em estudo, assim como na maior parte das cidades brasileiras, até os anos 60, a IP era através de lâmpadas incandescentes e em alguns lugares lâmpada fluorescentes. A partir da década de 70, começou a introdução das lâmpadas de vapor de mercúrio (brancas) na IP. Posteriormente, a partir dos anos 90, houve a introdução das lâmpadas de vapor de sódio (amarelas) e mais recentemente, está havendo um avanço das lâmpadas de vapor metálico (brancas) e também das lâmpadas de Led (brancas).

Foi identificado um total de 21.370 unidades na região em estudo, conforme tabela 15: 
Tabela 15: Quantidade de lâmpadas por tipo

\begin{tabular}{lclc}
\hline \multicolumn{1}{c}{ LÂMPADAS } & \multicolumn{1}{c}{ LÂMPADAS } \\
TIPO & QTD. & \multicolumn{1}{c}{ TIPO } & QTD. \\
\hline Vapor de Sódio-250 W & 6662 & LED-87 W & 255 \\
Vapor de Mercúrio-400 W & 4907 & Vapor de Sódio-70 W & 243 \\
Vapor de Sódio-400 W & 2161 & LED-52 W & 226 \\
Vapor de Mercúrio-250 W & 1803 & LED-26.4 W & 145 \\
LED-56 W & 1590 & LED-125.6 W & 137 \\
Vapor de Sódio-150 W & 1198 & Vapor Metálico-400 W & 102 \\
LED-100 W & 799 & Vapor Metálico-100 W & 56 \\
Vapor de Sódio-100 W & 441 & Vapor Metálico-150 W & 28 \\
Vapor de Mercúrio-125 W & 319 & Vapor Metálico-250 W & 27 \\
Incandescente-40 W & 288 & & $\mathbf{2 1 . 3 8 7}$ \\
\multicolumn{1}{c}{ TOTAL } & & & \\
\hline
\end{tabular}

Fonte: Autor, 2013

\section{Caracterização das anomalias}

No momento do cadastramento foram identificadas as anomalias demonstradas na tabela 16 .

Tabela 16: Anomalias em lâmpadas por tipo

\begin{tabular}{rc}
\hline ANOMALIA & QTD. \\
\hline Lâmpada quebrada & 31 \\
Lâmpada pendente & 5 \\
Lâmpada oscilando & 2 \\
TOTAL & $\mathbf{3 8}$ \\
\hline
\end{tabular}

Fonte: Autor, 2013

Gráfico 12: Percentual de anomalias em lâmpadas por tipo

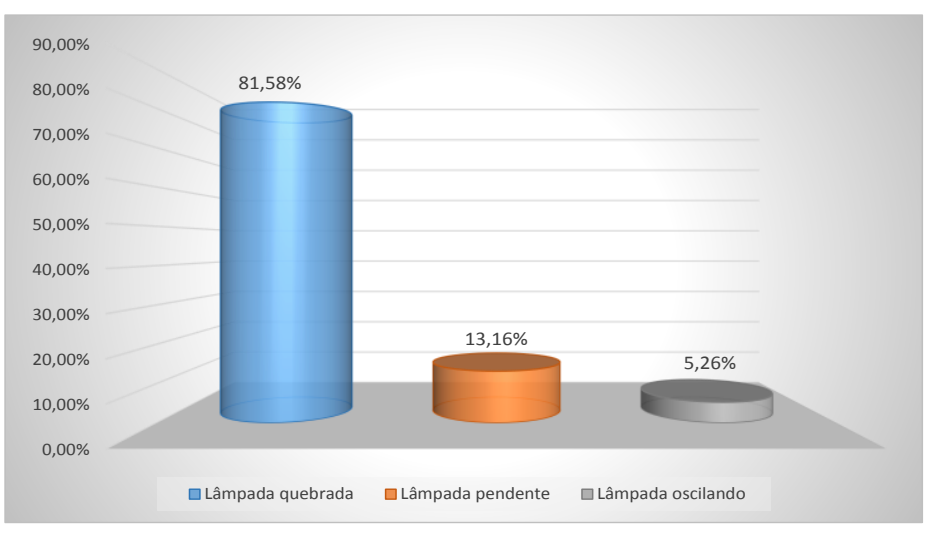

Fonte: Autor, 2013 


\section{Análise Técnica}

Considerando o total de 38 anomalias encontradas na região, se observa que a maioria diz respeito a lâmpadas quebradas $(81,58 \%)$, conforme demonstrado no gráfico 12 , o que demonstra a possibilidade de ações de vandalismo na região, porém, se analisarmos os dados em relação a quantidade de lâmpadas existentes (21.387), temos uma representatividade muito pequena, que não chega a $1 \%$, o que indica que a manutenção está eficiente, sem necessidade de ações complementares.

\section{h) Estudo Luminotécnico}

Nas medições efetuadas na região em estudo, foram identificadas as iluminâncias demonstradas na tabela 17.

Tabela 17: Medições luminotécnicas por classe

\begin{tabular}{|c|c|c|c|c|}
\hline $\begin{array}{l}\text { CLASSEDE } \\
\text { CLÂ }\end{array}$ & $\begin{array}{c}\text { QUANT. DE } \\
\text { PONTOS } \\
\text { ANALISADOS } \\
\end{array}$ & $\begin{array}{c}\text { ILUMINÂNCIA } \\
\text { MÉDIA } \\
\text { (Lux) }\end{array}$ & $\begin{array}{c}\text { DISTÂNCIA } \\
\text { PERCORRIDA } \\
(\mathbf{K m}) \\
\end{array}$ & $\begin{array}{c}\text { ÁREA DE } \\
\text { ABRANGENCIA } \\
\left(\mathbf{K m}^{2}\right) \\
\end{array}$ \\
\hline (Lux) & 48.449 & \multirow{8}{*}{18,16} & \multirow{8}{*}{534,72} & \multirow{8}{*}{7,37} \\
\hline Classe I (0-2) & 7.052 & & & \\
\hline Classe II (2-5) & 10.366 & & & \\
\hline Classe III (5-10) & 10.102 & & & \\
\hline Classe IV (10-20) & 9.323 & & & \\
\hline Classe V (20-50) & 7.929 & & & \\
\hline Classe VI (50-100) & 2.900 & & & \\
\hline Classe VII (>100) & 777 & & & \\
\hline
\end{tabular}

Fonte: Autor, 2013

\section{Caracterização das medições}

Foram efetuadas 48.449 medições ao longo das redes de IP da região em estudo. A fim de uma melhor análise dos dados coletados, os valores encontrados foram agrupados conforme uma classificação criada a partir de orientações da NBR-5101, demonstrados na tabela 18 . 
Tabela 18: Percentual de medições luminotécnicas por classe

\begin{tabular}{cc}
\hline ESCALA (Lux) & \% \\
\hline Classe I (0-2) & $15 \%$ \\
Classe II (2-5) & $21 \%$ \\
Classe III (5-10) & $21 \%$ \\
Classe IV (10-20) & $19 \%$ \\
Classe V (20-50) & $16 \%$ \\
Classe VI (50-100) & $6 \%$ \\
Classe VII (>100) & $2 \%$ \\
\hline
\end{tabular}

Fonte: Autor, 2013

\section{Gráfico 13: Percentual de medições luminotécnicas por classe}

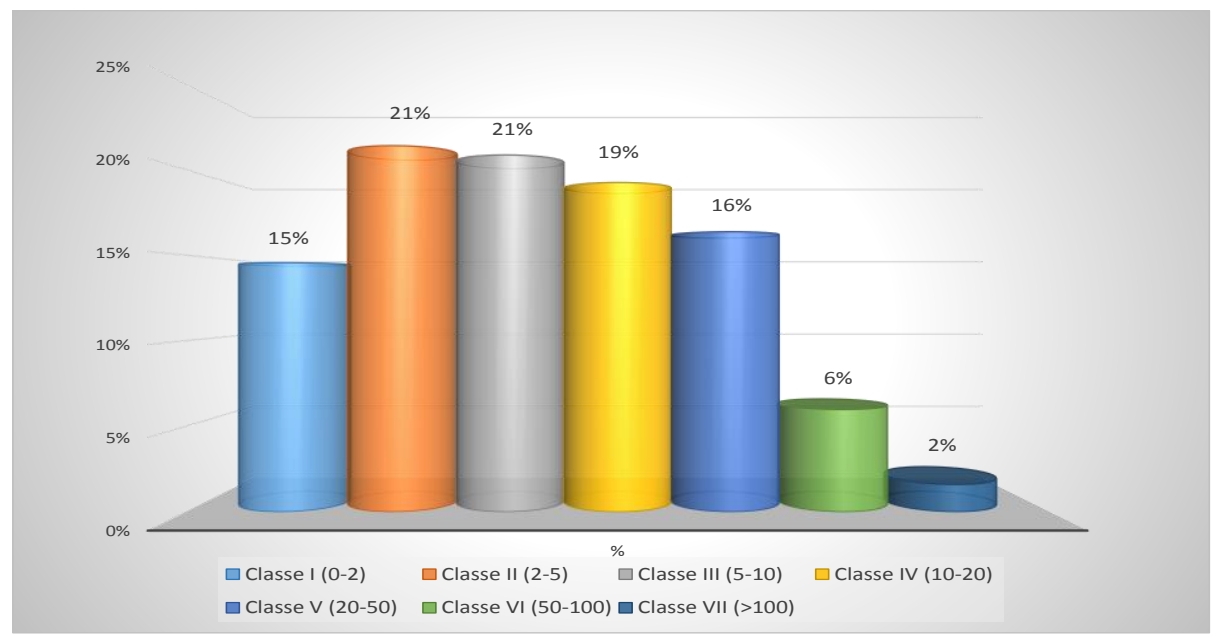

Fonte: Autor, 2013

\section{Análise Técnica}

A norma NBR 5101 (2012) cita que existem estudos que apontam que a distância mínima necessária para uma pessoa reconhecer qualquer sinal de hostilidade e tomar ações evasivas, é de 4 metros. A esta distância, o nível de iluminamento médio mínimo necessário para reconhecimento facial é de 3 Lux, sendo que sobre a superfície da via não pode haver valores inferiores a 1 Lux. As recomendações de iluminação estão em classes, de V1 a V5 para veículos e de P1 a P4 para pedestres. As classes são selecionadas de acordo com a função da via, da densidade, complexidade e separação do tráfego e da existência de facilidades para o controle de tráfego, como os sinais de transito. Nos exemplos típicos existentes nas tabelas 3 a 7 da NBR-5101/2012, constam o valor de iluminância média mínima para vias de tráfego de veículos (V5) igual a 5 Lux e para pedestres (P4) igual a 3 Lux, respeitando a descrição de cada tipo de via. 
Conforme observado na tabela 18, os pontos identificados como classe I e II, apresentam um nível médio de iluminância abaixo de 5 Lux, ou seja, abaixo do mínimo adequado para qualquer situação ou ambiente, que é acima de 5 Lux, considerando a condição de utilização mútua da via por veículos e pedestres. Já nas classes III e IV apresentam um nível médio de iluminância intermediário, que depende da classificação da via, portanto necessitam de uma avaliação mais aprofundada, mas dependendo do resultado, pode aumentar os números de pontos escuros. Já nas classes V (20 a 50), VI (50 a 100) e VII (mais de 100) - Iluminação é suficiente para qualquer tipo de Via, ou seja, aparentemente não necessitariam de intervenções, porém isso só será garantido se for confirmado que se trata de valores pertinentes apenas as luminárias avaliadas, sem influência de fonte luminosa externa ao sistema de IP, como por exemplo, um “outdoor iluminado".

Em vista do exposto, podemos dizer que na região estudada existem $36 \%$ de pontos identificados como "pontos escuros" (Classes I e II), lembrando que alguns desses pontos podem estar sofrendo interferência de arborizações, lâmpadas queimadas, luminária suja e/ou em mal estado, etc., razão pela qual se faz necessário um adequado estudo de cruzamento de dados para que se possam identificar os pontos escuros propriamente ditos. 


\section{ANÁLISE DOS DADOS}

De posse das informações apresentadas, foi efetuado um cruzamento dos dados levantados em campo, como os dados do IBGE, apresentados na tabela 19:

Tabela 19: Cruzamento de dados IBGE e dados coletados

\begin{tabular}{lc}
\hline \multicolumn{2}{c}{ Dados Demográficos X Dados Técnicos da Cidade em Estudo } \\
\hline Área $\left(\mathrm{km}^{2}\right)$ & 27 \\
População (2010) & 344.632 \\
Densidade Demográfica (Hab./km²) & 13,01 \\
Pot. Trafos Instalados (KVA) & 9.535 \\
Quant. Lâmpadas Instaladas (Unid.) & 21.387 \\
Potência Instaladas Lâmpadas (KW) & 5.517
\end{tabular}

Fonte: Autor, 2013

Como podemos observar, a região apresenta uma quantidade de transformadores instalados que totalizam 9,5 MVA, que fornecem energia para uma quantidade de lâmpadas que totalizam 5,52 MW. A potência consumida dos reatores acrescenta em média $10 \%$ na potência da lâmpada, portanto, consideramos que o conjunto lâmpadas e reatores consumam aproximadamente $6 \mathrm{MW}$. Pelo observado, existe uma aparente ociosidade de $36,84 \%$ nos transformadores, que podem ser objeto de novos estudos que possibilitem um melhor aproveitamento dessa potência disponível. Em função das condições dos transformadores encontrados em campo, é recomendável que os equipamentos passem por uma manutenção preventiva para que possam assumir novas cargas.

$\mathrm{Na}$ região estudada a administração pública está dividida por sub-regiões administrativas, tendo em vista ser uma região de alta densidade demográfica (13.000 habitantes por $\mathrm{Km}^{2}$ ), portanto a análise dos dados e IP levantados também foram segmentados, conforme apresentado na tabela 20. 
Tabela 20: Análise estatística dos dados

\begin{tabular}{|c|c|c|c|c|}
\hline $\begin{array}{c}\text { Região de } \\
\text { Estudo }\end{array}$ & $\begin{array}{c}\text { População } \\
\text { Total }(\mathbf{2 0 1 0}) \\
(\text { Hab. })\end{array}$ & $\begin{array}{c}\text { Iluminância } \\
\text { Média } \\
(\mathbf{L u x})\end{array}$ & $\begin{array}{c}\text { Potência } \\
\text { Instalada } \\
(\mathbf{K W})\end{array}$ & $\begin{array}{c}\text { Média da Área de } \\
\text { Abrangência } \\
\left(\mathbf{k m}^{\mathbf{2}}\right)\end{array}$ \\
\hline & & $\mathbf{A}$ & $\mathbf{B}$ & $\mathbf{C}$ \\
\hline Sub-Reg. I & 130.484 & 17,09 & 1.455 & 2,57 \\
\hline Sub-Reg. II & 83.368 & 18,15 & 2.136 & 2,40 \\
\hline Sub-Reg. III & 130.780 & 20,59 & 1.633 & 2,88 \\
\hline TOTAL & $\mathbf{3 4 4 . 6 3 2}$ & $\mathbf{1 8 , 7 0}$ & $\mathbf{5 . 2 2 4}$ & $\mathbf{7 , 8 5}$ \\
\hline
\end{tabular}

\section{Fonte: Autor, 2015}

Analisando estes dados, observamos que a Sub-Região III apresenta uma IP melhor que as demais já que a iluminância média é maior, porém, a fim de confirmar essa dedução inicial, foi feito um cruzamento de dados entre a potência instalada e a área de abrangência da medição de iluminância, que possibilitou analisar o gasto energético de cada sub-região (Tabela 21).

Tabela 21: Gasto energético por sub-região

\begin{tabular}{|c|c|c|c|c|c|c|}
\hline $\begin{array}{l}\text { Região de } \\
\text { Estudo }\end{array}$ & $\begin{array}{c}\text { População } \\
\text { Total (2010) } \\
\text { (Hab.) }\end{array}$ & $\begin{array}{l}\text { Iluminância } \\
\text { Média } \\
\text { (Lux) }\end{array}$ & $\begin{array}{c}\text { Potência } \\
\text { Instalada } \\
\text { (KW) }\end{array}$ & $\begin{array}{c}\text { Média da Área de } \\
\text { Abrangência } \\
\left(\mathbf{k m}^{2}\right)\end{array}$ & $\begin{array}{c}\text { Potência Instalada } \\
\text { por Área de } \\
\text { Abrangência } \\
\left(\mathbf{K W} / \mathbf{K m}^{2}\right)\end{array}$ & $\begin{array}{l}\text { Gas to Energético } \\
\qquad \underline{\mathbf{K W} / \mathbf{K m}^{2}} \\
\mathbf{L u x}\left(\mathbf{L m} / \mathbf{K m}^{2}\right)\end{array}$ \\
\hline & & $\mathbf{A}$ & B & C & $(B / C)=D$ & $\mathrm{D} / \mathrm{A}=\mathrm{E}$ \\
\hline Sub-Reg. I & 130.484 & 17,09 & 1.455 & 2,57 & 566 & 33 \\
\hline Sub-Reg. II & 83.368 & 18,15 & 2.136 & 2,40 & 890 & 49 \\
\hline Sub-Reg. III & 130.780 & 20,59 & 1.633 & 2,88 & 567 & 28 \\
\hline TOTAL & 344.632 & 18,70 & 5.224 & 7,85 & 665 & 36 \\
\hline
\end{tabular}

Fonte: Autor, 2015

Como podemos observar a Sub-Reg. III realmente apresenta melhores resultados tanto na potência instalada por área de abrangência $(\mathrm{KW} / \mathrm{Km})$ quanto no gasto energético (KW/Lux), ou seja, a IP lá existente ilumina mais gastando menos que nas demais subregiões, demonstrado no gráfico 14 . 
Gráfico 14: Gasto energético por sub-região

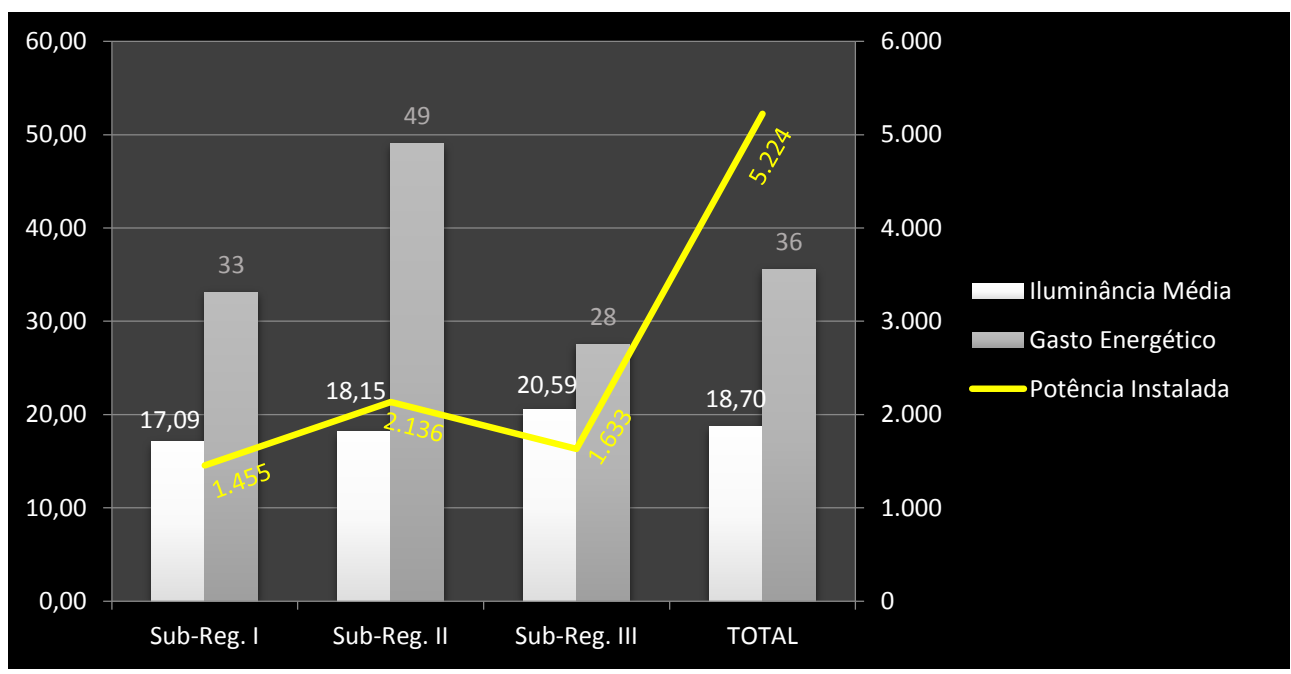

Fonte: Autor, 2015

Partindo para uma análise financeira, podemos identificar qual o custo da energia por sub-região, considerando a tarifa B4 (Iluminação Pública) da Eletropaulo de março/2015 (R\$ 0,09634), apresentados na tabela 22.

Tabela 22: Análise financeira

\begin{tabular}{|c|c|c|c|c|c|c|}
\hline $\begin{array}{c}\text { Eficiência } \\
\text { Financeira por }\end{array}$ & $\begin{array}{c}\text { População Total } \\
\text { 2010 } \\
\text { (Hab.) }\end{array}$ & $\begin{array}{c}\text { Valor da Conta } \\
\text { de Energia Total } \\
\text { (R\$) } \\
\end{array}$ & $\begin{array}{c}\text { Iluminância } \\
\text { Média } \\
\text { (Lux) }\end{array}$ & $\begin{array}{c}\text { Média da Área de } \\
\text { Abrangencia } \\
\left(\mathbf{k m}^{2}\right)\end{array}$ & $\begin{array}{c}\text { Custo mensal por } \\
\mathbf{K m}^{2} \\
(\mathbf{R} \$) \\
\end{array}$ & $\begin{array}{c}\text { Custo mensal por } \\
\text { habitante da Região } \\
\text { (R\$) }\end{array}$ \\
\hline & A & B & $\mathrm{C}$ & D & $E=B / D$ & $\mathrm{~F}=\mathrm{B} / \mathrm{A}$ \\
\hline Sub-Reg. I & 130.484 & $\mathrm{R} \$ 50.261,19$ & 17,09 & 2,57 & $\mathrm{R} \$ 19.556,88$ & $\mathrm{R} \$ 0,39$ \\
\hline Sub-Reg. II & 83.368 & $\mathrm{R} \$ 73.804,78$ & 18,15 & 2,40 & $\mathrm{R} \$ 30.751,99$ & $\mathrm{R} \$ 0,89$ \\
\hline Sub-Reg. III & 130.780 & $\mathrm{R} \$ 56.423,34$ & 20,59 & 2,88 & $\mathrm{R} \$ 19.591,44$ & $\mathrm{R} \$ 0,43$ \\
\hline TOTAL & 344.632 & R\$ $180.489,32$ & 18,70 & $\mathbf{7 , 8 5}$ & $\mathrm{R} \$ 22.992,27$ & $\mathbf{R} \$ 0,52$ \\
\hline
\end{tabular}

Fonte: Autor, 2015

Como podemos observar a Sub-Reg. III apresenta melhores resultados, especialmente relativo ao custo mensal por habitante.

Em resumo podemos dizer que a IP mais eficiente apresentada na Sub-Região III, apresenta um melhor custo/benefício, se comparada Sub-Regiões I e II.

Evidentemente que à IP não pode ser repartida e apropriada a cada habitante, já que é um bem comum, que todos usam independentemente de onde moram, mas nos permite ter um comparativo que podemos utilizar para planejar a cidade considerando o grau de 
importância de cada região, especialmente considerando o que cada municipe paga pela Contribuição de Iluminação Pública - CIP.

Com o Estudo Luminotécnico, que identificou diversos pontos escuros, poderá auxiliar na mitigação desse problema, já que existe carga ociosa de potência de transformação, porém deve-se tomar o cuidado para eliminar os pontos com interferências com árvores, já identificados nas anomalias, que podem estar influenciando esses pontos escuros. 


\section{CONSIDERAÇÕES FINAIS}

Com a quantidade de dados levantados em um processo de cadastramento técnico é possível elaborar relatórios de diagnóstico por região da cidade, tendo em vista que cada região tem necessidades diferentes, especialmente no período noturno. É possível inclusive desenvolver um modelo de manutenção preventiva e preditiva, considerando a utilização dos espaços noturnos, levando em consideração os equipamentos de utilização pública noturna existente na região, como faculdades, hospitais, teatros, etc.

Há que se considerar que algumas regiões da cidade, que são importantes e intensamente utilizadas durante o dia, não tem a mesma relevância durante a noite. Exemplo disso é a região da Praça da Sé em São Paulo, que apesar de suma importância durante o dia, à noite torna-se uma área bem menos frequentada, se comparado com a frequência diurna, excluindo-se áreas onde existem escolas, hospitais, etc.

Apesar de não ter enfoque neste estudo, também é possível proceder a uma revisão da conta de consumo de energia destinado a IP, que pode ser aferida, já que é possível apurar o que realmente está instalado e seu regime de funcionamento, haja vista que muitas vezes se paga por uma lâmpada que se encontrou um bom período apagado, sem contar que não é difícil nos depararmos com instalações onde, na fatura de consumo está definido como sendo uma potência de lâmpada maior do que a que está em funcionamento, onerando assim os cofres públicos.

Outro subproduto do cadastramento é a possibilidade de elaboração de um planejamento da cidade, ou seja, um Plano Estratégico exclusivo de IP da Cidade, levando em consideração seus marcos históricos, seus monumentos, suas características turísticas e operacionais.

Compreender a dinâmica de ocupação do espaço urbano é fundamental para acompanhar a dinâmica de funcionamento noturno desse espaço. É fácil perceber que se é construído um novo shopping center numa região, as necessidades do entorno são alteradas, mas muitas vezes o mesmo não acontece com estruturas noturnas menores. Quando se inaugura uma escola, um novo condomínio, um novo restaurante ou casa de lazer noturna (teatro, cinema, bares, etc.) algo muda na vida noturna da região, necessitando que os serviços públicos que atendem à demanda noturna se adaptem e atendam a essa nova rotina dos usuários, seja em IP, transporte, etc. 
O que se propõem é que se estabeleça uma rotina de diagnosticar e aferir se um serviço público está adequado às necessidades dos usuários e assim, respeitar os impostos pagos pelos contribuintes que esperam um retorno ao que é recolhido, além de evitar desperdícios em gastos que não são percebidos pelos usuários finais. $\mathrm{O}$ instrumento apresentado neste estudo almeja ser uma ferramenta que possa contribuir para que o serviço público "IP" seja flexível o suficiente para conseguir acompanhar as alterações que todas as cidades sofrem durante seu desenvolvimento.

A experiência de gerenciamento de ativos evoluiu muito depois das privatizações do setor elétrico, quando foi possível observar a mudança na forma de exploração do ativo, que passou a ter orientação estratégica de retorno financeiro. A iluminação pública também foi objeto dessa evolução, principalmente após incentivos governamentais, como o Reluz, promovidos pelo Governo Federal, visando à eficiência energética.

Hoje, temos uma necessidade de olhar a IP de uma forma diferenciada, não apenas como um sistema que provem luz nas vias públicas. Conforme descrito na introdução da NBR 5101/2012 vigente, “[...] Os projetos de IP devem atender aos requisitos específicos do usuário (grifo nosso), provendo benefícios econômicos e sociais para os cidadãos“[...], ou seja, é notória a necessidade de um produto e serviço que agregue valor a uma população que utiliza cada vez mais os espaços públicos em períodos noturnos, com segurança e satisfação, pagando um preço justo que remunere os investimentos em novas tecnologias.

Conforme Pfeiffer (2000), a falta de métodos modernos com instrumentos e procedimentos adequados na administração pública, em nível municipal é gritante e exige mudanças urgentes.

Prover os gestores municipais de instrumentos adequados de levantamento do ativo é condição primordial para uma boa gestão do ativo de IP, trazendo benefícios não só para o erário público, pois saberá com certeza o que está pagando as Concessionárias, como também permitindo que o usuário final perceba visualmente os benefícios de uma boa gestão municipal.

O que se discute não é necessariamente quem deve gerir o acervo de IP de um município, mas como deve ser gerido esse patrimônio municipal que tanto faz pela qualidade de vida da população. 
Saber o que se tem nas mãos é saber tomar as decisões certas e com menos custos, independente se os ativos de IP estão sob um regime de PPP (Parceria Público Privado) ou gestão direta municipal. 


\section{REFERÊNCIAS}

AGENCIA NACIONAL DE ENERGIA ELÉTRICA - ANEEL. Resolução Normativa no 456 de 29 de novembro de 2000. Estabelece as Condições Gerais de Fornecimento de Energia Elétrica. Brasília, 2000

Resolução Normativa no 414 de 09 de setembro de 2010. Condições Gerais de Fornecimento de Energia Elétrica. Brasília, 2010.

Resolução Normativa no 479: Altera a Resolução Normativa $n^{\circ}$ 414, de 9 de setembro de 2010, que estabelece as Condições Gerais de Fornecimento de Energia Elétrica de forma atualizada e consolidada. Brasília, 2012

Resolução Normativa no 480: Altera a Resolução Normativa $n^{\circ}$ 414, de 9 de setembro de 2010, que estabelece as Condições Gerais de Fornecimento de Energia Elétrica de forma atualizada e consolidada. Brasília, 2012

Resolução Normativa no 587: Altera o art. 218 da Resolução Normativa ANEEL n 414 , de 9 de setembro de 2010. Brasília, 2013

Transferência dos Ativos de IP. Disponível em:

http://www.aneel.gov.br/aplicacoes/noticias/Output_Noticias.cfm?Identidade=8276\&i d_area=90. Acesso em: 03/12/2014.

ASSOCIAÇÃO BRASILEIRA DE NORMAS TÉCNICAS. NBR 5101. Iluminação Pública $\mathrm{n}^{\circ}$ 5101. Rio de Janeiro, 2012.

NBR 5462. Confiabilidade e Mantenabilidade. Rio de Janeiro, 1994.

NBR 5426. Planos de amostragem e procedimentos na inspeção por atributos Rio de Janeiro, 1985.

AURELIANO, L. M. Descentralização de política social: alguns exemplos da saúde, educação assistência. São Paulo. Konrad-Adenauer-Stiftung, n.10, p.25-31, 1996. 
BALDWIN, R.; CAVE, M. Understanding regulation: theory, strategy, and practice. Oxford: University of Oxford, 1999. 363 p.

BARBOSA, R. A gestão e o uso eficiente de energia elétrica nos sistemas de IP. 2000. 195p. Dissertação (Mestrado) - Escola Politécnica e Energia Universidade de São Paulo, São Paulo, 2000.

BASSO, Rafael Leão Rego. Plano diretor de iluminação urbana do centro histórico de São Paulo: uma nova ambiência e atmosfera para os calçadões. 2008 215p. Dissertação (Mestrado) - Faculdade de Arquitetura e Urbanismo. Universidade de São Paulo, 2008.

BRASIL. PRESIDENCIA DA REPÚBLICA. CASA CIVIL - SUBCHEFIA PARA ASSUNTOS JURÍDICOS. Constituição da República Federativa do Brasil de 1988. Brasília, 1988.

CABRAIA, M. S. Proposta de um sistema de gestão da IP para municípios de pequeno a médio porte. 2003. 170 p. Dissertação (Mestrado) - Escola Politécnica da Universidade de São Paulo, 2003.

CAMPOS, S. J. F. Iluminação urbana: um estudo da eficiência de luminárias LED controladas por sistema de tele-gestão. 2013. 133 p. Dissertação (Mestrado) - Faculdade de Engenharia de Produção. Universidade Metodista de Piracicaba, Piracicaba. 2013.

EMPRESA DE PESQUISA ENERGÉTICA - EPE. Anuário Estatístico de Energia Elétrica 2013 Brasília, 2014.

ENCYCLOP ÆDIA BRITANNICA - School \&Library. Britannica Digital Learning. Disponível em: http://global.britannica.com. Acessado em: 21/10/2014.

EXTECH. Instrumentos de Testes e Medições. [s.1.]: n.d.

FEDERAÇÃO NACIONAL DOS ENGENHEIROS: Nota Técnica - avaliação regulatória. Transferência dos ativos de IP das distribuidoras para os municípios. Brasília. Disponível em: file://C:/Users/manoel.galdino/Downloads/fne\%20$\% 20$ nota $\% 20$ tcnica\%20\%20avaliao\%20regulatria\%20e\%20jurdica\%20(1).pdf. Acesso em: $22 / 11 / 2014$. 
GERHARDT, T.E.; SILVEIRA, D.T. Métodos de Pesquisa. Porto Alegre: UAB/UFRGS. 2009. 120 p. Disponível em: http://books.google.com.br/books?hl=pt-

BR\&lr=\&id=dRuzRyEIzmkC\&oi=fnd\&pg=PA9\&dq=pesquisa + quantitativa + goldenberg $\&$ ots=91PfV1mqPD\&sig=hpimqo5XTHVlBqWnraTqDP7PZi0\#v=onepage $\& q=$ pesquisa $\% 2$ 0quantitativa\%20goldenberg\&f=false. Acesso em: 21/07/2014.

GILl, A. C. Como elaborar projetos de pesquisa, 4. ed. São Paulo: Atlas, 2002.

GOEKING, W. Eletricidade e desenvolvimento, publicado em janeiro de 2010, edição 48 da revista "O Setor Elétrico". Disponível em: http://www.osetoreletrico.com.br/web/arevista/ediçoes/232-eletricidade-e-desenvolvimento.html revista/ediçoes/232-eletricidadee-desenvolvimento.html Acesso em: 20/10/2014.

DEPARTAMENTO DE ILUMINAÇÃO PÚBLICA DA CIDADE DE SÃO PAULO ILUME. Relatório de Realizações 2013. Disponível em:

https://www.google.com.br/?gfe_rd=cr\&ei=CmihVNTaG4aw8wfvioLwCQ\&gws_rd=ssl\# $\mathrm{q}=\mathrm{em}+\mathrm{S} \% \mathrm{C} 3 \% \mathrm{~A} 3 \mathrm{o}+\mathrm{Paulo}+17.000+\mathrm{km}+\mathrm{de}+\mathrm{vias}+\mathrm{p} \% \mathrm{C} 3 \% \mathrm{BAblicas},+\mathrm{que}+$ corresponde $+\mathrm{a}+$ um+consumo+mensal+de+aproximadame nte+165+GWh\&tbs=qdr:y. Acesso em: $25 / 11 / 2014$.

EUROPEAN COMMISSION. Lighting the Cities - Accelerating the Deployment of Innovative Lighting in European Cities. Brussels, Belgium: Luxembourg: Publications Office of the European Union. 2013.

INSTITUTO BRASILEIRO DE GEOGRAFIA E ESTATÍSTICA - IBGE. Sistema de geodésico de referência. Disponível em:

http://www.ibge.gov.br/home/geociencias/geodesia/pmrg/faq.shtm\#1. Acesso em $25 / 11 / 2014$.

IWASHITA, J. O papel social da luz urbana. Revista O Setor Elétrico, ed. 69, outubro 2011. Disponível em: http://www.osetoreletrico.com.br/web/a-empresa/745-o-papel-socialda-luz-urbana.html da-luz-urbana.html. Acesso em: 21/10/2014.

KURAHASSI, L. F. Gestão da energia elétrica: bases para uma política pública municipal. 2006. 267p. Tese (Doutorado) - Departamento de Engenharia de Energia e Automação Elétrica, Escola Politécnica da Universidade de São Paulo, 2006. 
LOPES, L. B. Uma avaliação da tecnologia LED na IP. 2014. 81 p. Monografia- Escola Politécnica da Universidade Federal do Rio de Janeiro, 2014.

MARTINS, J. O papel social da luz urbana, publicado em outubro de 2011, no site Portal do Setor Elétrico. Disponível em: -

http://www.osetoreletrico.com.br/web/component/content/article/57-artigos-ematerias/745o-papel-social-da-luz-urbana.html. Acesso em: 24/03/2013.

MEYRICK \& ASSOCIATES. Eletricity Service Quality Incentives Scoping Paper. Queensland Competition Authorith. 2002. Disponível em: file:///F:/DISSERTA\%C3\%87\%C3\%830\%20FINAL/REFER\%C3\%8ANCIAS\%20BIBLI OGR\%C3\%81FICAS/TEXTOS/MeyrickAndAssociates_Electricity_Service_Quality.pdf. Acesso em: 13/09/214.

MEDRAL GEOTECNOLOGIA. Trabalho de levantamento luminotécnico. São Paulo, 2012

MICHAELIS. Dicionário da Língua Portuguesa. Disponível em: http://michaelis.uol.com.br/moderno/portugues/index.php?lingua=portuguesportugues\&palavra=diagn\%F3stico. Acessado em 05/08/2014.

NASA, 2014. Visão noturna da região da Itália (Estação Espacial, NASA, 2014). Disponível em: http://www.gazetadopovo.com.br/mundo/conteudo.phtml?id=1487842. Acesso em: 04/12/2014

PFEIFFER, P. Planejamento estratégico municipal no Brasil: uma nova abordagem. Brasília: ENAP, 2000.

PINHEIRO, T. M. M. Regulação por incentivo à qualidade: comparação de eficiência entre distribuidoras de energia elétrica no Brasil. 2012. 157p. Dissertação (Mestrado) Faculdade de Tecnologia - Universidade de Brasília. DF, 2012.

PROGRAMA NACIONAL DE CONSERVAÇÃO DE ENERGIA ELÉTRICA (Brasil). PROCEL. RELUZ/Programas. Disponível em: http://www.eletrobras.com/elb/data/Pages/LUMIS0389BBA8PTBRIE.htm Acesso em: 03/12/2014. 
PROCEL. RELUZ: manual de instruções / PROCEL, PROCEL RELUZ - Ed. Atual. Rio de Janeiro: ELETROBRÁS, 2004. 60 p.: il.

SAIDEL, M. A. et al. Um programa abrangente de racionalização do uso da energia no setor bancário. O exemplo da Caixa Econômica Federal. In: XVII SNPTEE, 2003

SANTOS, C. R. A. Iluminação pública e sustentabilidade energética. 2011 155p.

Dissertação (Mestrado) - Faculdade de Engenharia da Universidade do Porto. Porto, 2011.

SCHEREDER. Catálogo de Iluminação Pública, 2014. Disponível em: http://www.schreder.com/pts-pt/Pages/default.aspx. Acesso em: 16/12/2014

SECRETARIA DE ENERGIA. CEPAM. IP - Guia do Gestor. São Paulo: CEPAM - Centro de Estudos e Pesquisa de Administração Municipal. São Paulo, 2013. 36p.

SILVA, A. L. R. Monografia fácil: ferramentas e exercícios. 2. ed. São Paulo: DVS Editora, 2004.

SILVA, L. L. F. IP no Brasil: aspectos energéticos e institucionais. Rio de Janeiro. 2006. 161 p. Dissertação (Mestrado) - Universidade Federal do Rio de Janeiro, COPPE, 2006.

ROSITO, L. H. As origens da IP no Brasil. Revista "O Setor Elétrico". n. 36. Janeiro de 2009.

WEINERT, J. LED Lighting Explained - Undertanding LED Sources, Fixtures, Applications and Opportunities. Burlington, Massachusetts, USA: Philips Solid-State Lighting Solutions Inc. 2010. 